\title{
LOS PRINCIPIOS FUNDAMENTALES DEL DERECHO \\ INTERNACIONAL, EN LA DOCTRINA \\ DE ALEJANDRO ALVAREZ (*)
}

- Diez Clases -

(1957 - 1958)

RENE-JEAN DUPUY

Profesor de la Facultad de Derecho y Ciencias Econórsicas de Niza. Secretario General de ta Academia de Derecho Internacional de La Haya.

\section{PRESENTACION}

El ilustre internacionalista Profesor René-Jean Dupuy desarrolló en el año académico 1957-1958 un curso profundizado sobre los principios fundamentales del Derecho Internacional en la doctrina de Alejandro Alvarez, que fue dictado en el Instituto de Altos Estudios Internacionales de la Universidad de Paris y publicado originalmente en francés por la Asociación de Estudios Internacionales.

El conjunto de diez clases que conforman este curso constituye uno de los ensayos mejor logrados en torno a la interpretación, sistematización y análisis científico del pensamiento jurídico de Alejandro Alvarez. Por tal motivo hemos considerado de sumo interés poner esta obra al alcance de la comunidad académica de habla hispana, para cuyo efecto hemos preparado su traducción y edición en español generosamente

(*) Traducción y edición en español preparada por Francisco Orrego Vicuña, Profesor de la Facultad de Ciencias Juridicas y Sociales de la Universidad de Chile. 
autorizados por el Profesor Dupuy. Su publicación en los Anales de la Facultad de Ciencias Jurídicas y Sociales de la Universidad de Chile, colección donde se han incluido en ocasiones anteriores los estudios más connotados sobre la obra de Alvarez, viene a completar el homenajc académico rendido por la Universidad de Chile a tan brillante pensador.

La importante trayectoria acadćmica del profesor RenéJean Dupuy es sobradamente conocida. En la actualidad se desempeña como Secretario General de la Academia de Derecho Internacional de La Haya y como Profesor de la Facultad de Derecho y Ciencias Económicas de Niza, lugar donde dirige también el Instituto de Derecho de la Paz y Desarrollo. Su destacada producción jurídica, que con particular énfasis ha versado sobre América Latina y el Sistema Interamericano, comprende obras de tanta trascendencia como "Le nouveau Panaméricanisme" (París, 1956) y como "Le Droit des relations entre les organisations internationales" (Leyde, 1961).

Como un testimonio más de la amistad personal que nos une con el Profesor Dupuy y del respeto académico que le profesamos, forjado a través de una estrecha colaboración en las variadas actividades de la Academia de Derecho Internacional de La Haya, nos complacemos en presentar en idioma castellano su estudio sobre don Alejandro Alvarez.

Septicmbre de 1971.

Francisco Orrego Vicuña. 


\section{INTRODUCCION}

He sido encargado de hablarles de las doctrinas de un jurista chileno, Alejandro Alvarez. Estc jurista ha celebrado hace un mes su $90^{\circ}$ aniversario y es la suya una larga vida consagrada al Derecho Internacional, vida que ha recibido múltiples y fastuosos homenajes durante una carrera científica que continúa todavía en la hora actual.

Algunos emanan de un presidente de los Estados Unidos. otros de instituciones internacionales, como la Organización de los Estados Americanos que hace algunas semanas, en el curso de una reunión de su Consejo Directivo, rendía homenaje a la obra científica de Alvarez. Ha habido palabras muy elogiosas pronunciadas a su respecto por juristas europeos, como el alemán Strupp, quien saludó en él a un nuevo Grotius. Ha habido el saludo constante de los latinoamericanos que no han dejado de ver en él "al más grande jurista de América Latina", según las palabras de uno de sus colegas, Yepes.

Alvarez es miembro del Instituto de Derecho Internacional, miembro del Instituto de Francia, uno de los creadores del Instituto de AItos Estudios Internacionales.

Ante la amplitud y la majestuosidad de estos homenajes debe hacerse una doble observación.

Algunos de estos homenajes emanan de hombres de Estado o de instituciones internacionales, otros de jurisconsultos o sabios. Alvarez ha llegado a los unos y a los otros porque ha participado en la vida internacional a través del estudio, pero también por medio de una acción creadora. Desde el inicio surgió como un reformador en las tres fases de su vida de internacionalista, en su triple calidad de profesor, diplomático y juez.

Como profesor, porque desde los veinticinco años de edad enseña Derecho Civil en Chile, donde nació. Pero no desea limitarse a su primera formación y muy pronto, en 1896, viene 
a París atraído por la reputación de la enseñanza de Louis Renault en la Facultad de Derecho, donde obtiene el grado de Doctor en Derecho, y por aquella de la Escuela Libre de Ciencias Políticas. Es en Francia donde se introduce en los problemas internacionales y del derecho comparado - que también le proporcionan ciertos aspectos de los problemas internacionales-y cuando en 1900 regresa a Chile publica su primera obra: "Reforma de los estudios políticos y jurídicos". Nuevamente en Francia en 1904 publica "Nouvelle conception des études juridiques et la codification des Droit Civil", traducida inmediatamente al inglés por la Asociación de Profesores de Derecho de los Estados Unidos. Aparecen ya en este libro dos términos del vocabulario de Alvarez y que tendrán un Iugar escogido en su obra: el calificativo de "nuevo" y "la codificación", que subsistirá como uno de sus temas fundamentales.

Recién terminada la primera guerra, en 1921, funda con Paul Fauchille y Alberto de La Pradelle este Instituto, donde él mismo enseñó en numerosas ocasiones. Entonces era conocido sobre todo como americanista; en 1912 había fundado en América, junto con el "Sollicitor", esto es, el asesor jurídico del Departamento de Estado, James Brown Scott, el Instituto Americano de Derecho Internacional, habiendo ya adquirido en el Nuevo Mundo una reputación definitiva.

Por otra parte en Europa, donde residía con mayor frecuencia, participaba en múltiples congresos científicos, a la vez que se desempeñaba igualmente en su calidad de diplomático.

Como diplomático se inició casi tan joven como de profesor. Pronto fue asesor jurídico del Ministerio de Relaciones Exteriores de Chile ocupando de esta mancra, desde el comienzo de su carrera, un lugar de observación de la vida internacional americana particularmente, pero también universal. En 1907 fue él quien redactó las instrucciones de los delegados de Chile a Ia Segunda Conferencia de La Haya. Más tarde, ya establecido en Europa, fue asesor jurídico de las Legaciones 
de Chile en este continente. De esta manera constantemente estuvo vinculado a los dos mundos, el viejo y el nuevo. En efecto participa en las conferencias panamericanas donde desempeña un importante rol, desde la Conferencia de Buenos Aires en 1910, luego en la de 1923 y sobre todo en la Sexta Conferencia que se reunió en La Habana y que fue desgarrada por la confrontación de los Estados del Sur y los Estados Unidos sobre el problema de la intervención, conferencia donde se elaboraron importantes estatutos del sistema interamericano y en el curso de la cual Alvarez ejerció una influencia determinante.

Pcro al mismo tiempo se encuentra con frecuencia en Europa y en la Sociedad de las Naciones; esta doble orientación americana y europea cncontrará finalmente su consagración y su unidad en la elección de Alejandro Alvarez en 1946 como Juez de la Corte Internacional de Justicia, donde permanecerá hasta 1955.

Como Juez se desempeña desde luego en la tradición americana, deseando utilizar su función para actuar sobre el desarrollo del Derecho gracias a las observaciones de la evolución de la vida internacional que sus análisis le permiten formular. Reformador como joven profesor cuando publicaba su primera obra - "La réforme du droit civil au Chili"-, continúa siendo un reformador cuando deja en 1955 la Corte de La Haya.

Su experiencia, en efecto, le ha servido sobre todo para medir la amplitud de las transformaciones que han marcado las relaciones internacionales durante su larga existencia. $\mathrm{Ha}$ elaborado toda una doctrina acerca de la inaptitud de una parte de las normas del Derecho Internacional clásico para expresar las nuevas necesidades sociales. Durante estos últimos veinte años se ha transformado en el campeón del Nuevo Derecho Internacional, particularmente en sus opiniones disidentes acerca de las sentencias u opiniones consultivas de la Corte Internacional de Justicia.

Es así como hasta el final ha permanecido fiel a su tem- 
peramento de reformador sin cesar de sostener, desde que se incorporó a la vida científica, la necesidad de tomar conciencia de la evolución del medio politico-jurídico, de las reglas que la rigen y sobre todo la necesidad de acelerar esta toma de conciencia en lo que respecta a las normas obsoletas. El régimen juridico tiende siempre a perpetuarse más allá de las modificaciones de las condiciones sociales que presidieron su entrada en vigor. De esta persistencia de un régimen jurídico nacido de condiciones sociales que han dejado de existir. de la persistencia de un régimen obsoleto o en vías de serlo, y de la aparición de nuevas necesidades sociales resultan crisis y tensiones que constituyen otras tantas amenazas para la paz; ciertamente el problema fundamental del Derecho Internacional es el problema de su revisión o de su adaptación pacífica.

Este esfuerzo constante de renovación es el que se nos aparece como el eje fundamental de la obra de Alvarez, y es este esfuerzo también el que explica los dos rasgos principales de este singular autor, rasgos que no han dejado de coexistir en sus diversas actividades y que en definitiva guardan armonía a pesar de su aparente contradicción: es el "continentalismo" de una parte y el "universalismo" de otra. Tales son los dos aspectos en que quisiera dividir esta introducción.

Regionalismo y universalismo

Alvarez ha sido el primero en sostener la existencia de un regionalismo internacional. Todos los juristas de la escuela latinoamericana e incluso numerosos juristas de los Estados Unidos, como James Brown Scott especialmente, ven en él al creador del Derecho Internacional americano. En 1910 publica una obra que efectivamente lleva este título. Se compenetra así de la tradición de Bolívar quien, fundamentándose en los vínculos existentes entre los pueblos de América Latina, diseñó en 1826 el tratado de unión, liga y confederación per- 
petua como proyecto para reunir a los pueblos y a las jóvenes repúblicas de América Latina que recién accedian a la independencia. Este proyecto no tuvo consecuencias inmediatas. Pero el "Sueño de Bolívar", como no ha dejado de llamársele desde entonces, contemplando por anticipado una Sociedad de Naciones Americanas, ha permanecido en los espíritus de los jurisconsultos del continente e inclusive de varios estadistas. Sin duda que también se encuentra en los orígenes del panamericanismo, que sólo se iniciaría en 1889 con la Primera Conferencia Interamericana convocada por los Estados Unidos. Ustedes saben que el sistema interamericano, como se le denomina, ha conocido una lenta evolución en medio de múltiples contradicciones continentales; se ha presentado como una larga búsqueda de una unidad contradicha por numerosos factores de divergencia. No resultaba negativo, e incluso era necesario, que en el momento de este lento caminar alguien iluminara los principales rasgos de esta "juricidad" continental que comenzaba a manifestarse en medio de múltiples contradicciones y confusiones. Este fue el rol de Alvarez.

$\mathrm{Y}$ si hoy en día, después de 1948 y la Novena Conferencia Interamericana, existe en el Nuevo Mundo una Organización de los Estados Americanos construida sobre la codificación de todos los tratados, pactos o esfuerzos institucionales que hasta entonces se habían realizado, es en gran medida a Alvarez que se le debe, puesto que él ha permitido tomar conciencia de un gran número de obstáculos que entrababan la acción del panamericanismo y sobrepasarlos. De tal suerte, en cierta medida, él surge como cl "vínculo doctrinal" entre Bolívar y la Carta de Bogotá.

Si bien la misión actual de esta intervención de Alvarez. en la vida científica, enarbolando la bandera de un derecho internacional americano, se nos aparece como un éxito, en su momento produjo escándalo.

Produjo escándalo pues hay que tener presente que la expresión Derecho Internacional Americano tiene dos significados. 
Por una parte, significa que el derecho internacional puede ser localizado y puede tener un particularismo regional que acarreará un particularismo jurídico.

Pero, por otra parte, desde el momento en que se ha manifestado un significado tal, se ha atentado en contra del carácter universalista del derecho de gentes y precisamente este segundo aspecto es el que chocaba. Chocó a los europeos, quienes, descendientes de Grotius, veían en el Derecho internacional un valor universal, y también chocó a los americanos, particularmente al profesor brasilero Sa Vianna, quien en 1912 respondía a Alvarez con una obra titulada "De la non existence du droit international américain". Fue esta una respuesta casi palabra por palabra que rememora un tanto la vieja lucha entre Grotius y Selden sobre el mare liberum y el mare clausum.

Este escándalo era sin embargo inevitablc. En la idea de un derecho internacional americano hay, en efecto, dos aspectos: el primero es que se trata de un derecho localizado en el espacio y que responde a consideraciones locales; el segundo es que participa de una dinámica del derecho. La situación deI derecho internacional americano no es estática y es sobre todo este ángulo el que nos hará comprender el escándalo. Es la reivindicación de una autonomia en una evolución que evidentemente se injerta en el tiempo. De esta manera es la reivindicación del reconocimiento de una situación, así como la reivindicación de un desarrollo, de una vida jurídica independiente. Aparece así como dirigida contra otros sistemas de derecho.

\section{El Derecho Internacional Americano es un derecho localizado}

Alvarez ha considerado esencialmente el medio jurídico del Nuevo Mundo. Estudiando este medio, testimonia desde 1910 - es necesario precisar esta fecha porque es una época 
en que esta manera de proceder es de suyo original- el uso de un método antes de llegar a una originalidad continental.

A. El método es analítico e inductivo: se defiende de ideas a priori; para él el único método aplicable en ciencias políticas, jurídicas o sociales es el método experimental. Está muy lejos por ejemplo del normativismo kelseniano. Solamente la experiencia le parece científica. El Derecho Internacional no tiene el objetivo, la estructura del derecho interno. Este último desde luego necesita de estudios para comprender sus reglas de base, históricas o sicológicas, que permiten darle una significación verdadera a los artículos de los códigos. Con mayor razón el derecho internacional, todavía frecuentemente consuetudinario, exige de investigaciones numerosas dentro del medio social.

De ahí que este método se aplique a descubrir las condiciones propias de la vida internacional de estos pueblos: condiciones geográficas, históricas, espirituales. Alvarez es el primero en descubrir en medio de múltiples diversidades, diversidades de raza, diversidades de religiones entre el norte y el sur, diversidades sociales -el estado social de América del Norte siendo evidentemente mucho más elevado que aquel de la Amćrica Latina-, ciertos factores de unidad. Estos son hoy día bien conocidos.

- Originalidad geográfica: La influencia del medio físico, sin una medida común con Europa, ha sido considerable sobre la formación de la neutralidad continental, tesis que será retomada en numerosas ocasiones por diversos autores y especialmente por André Siegfried.

- Originalidad histórica: Los americanos del norte y del sur son por esencia secesionistas, antieuropeos. En los americanos del norte este antieuropeismo ha estado en el origen muy marcado de las consideraciones y actitudes religiosas; basta pensar en estas frases terribles proferidas por Jefferson en las que dijo particularmente: "Desearía que exista un océano de llamas entre Europa y nosotros", la llama evocando un fuego purificador. Los americanos que dejaron Europa fueron 
a crear allá un nuevo mundo, un mundo que está fundado sobre la base de un rechazo de Europa y de sus miserias materiales, políticas y morales, y una afirmación de puridad. Hay un puritanismo en la formación de los Estados Unidos de América del Norte que, desde el inicio de su historia, los alejó de Europa. Entre los americanos del sur no se encuentra la misma reacción; pero finalmente se llega aproximativamente al mismo resultado: se trata de una hostilidad fundamentada en el anticolonialismo. Hubo un mestizaje que no se produjo en América del Norte y por este mestizaje, si bien los indios en alguna medida fueron bastante hispanizados, los espan̄oles mismos también sufrieron profundamente la influencia indígena y no resulta de más recordar que en el momento de las guerras de independencia, Atahualpa, el Inca asesinado por Pizarro, fue considerado un héroe nacional con el mismo título que Bolívar, que San Martín o Santander; hubo en ese momento una confusión al tomar en común todos los grandes hombres de la América iberoindígena, Ilevasen ellos un nombre español o un nombre indígena, lo que revelaba, por otra parte, en el plano de la mentalidad por lo menos, una cierta integración sicológica, espiritua1, de América del Sur.

En efecto, son estos elementos espirituales, sicológicos, que atracn esencialmente la atención de Alvarez, puesto que para él los factores políticos, los factores geográficos, los factores históricos o económicos no tienen interés sino en la medida que convergen hacia reacciones sicológicas; y prontamente sc presenta como el Jefe de una Escuela: la Escuela Sicológica.

Consideremos por nuestra parte la sicología del Nuevo Mundo. Ella está fundamentada sobre el optimismo, la fe en el progreso. La confianza del americano viene de su juventud y también de su éxito, del orgullo de haber vencido una naturaleza dificil, ruda, sin medida común con aquella de Europa, pero que dispensa riquezas considerables a aquellos que pueden vencerla. Finalmente este optimismo desemboca en una democracia, puesto que la democracia corresponde a 
una actitud que da confianza al hombre. No obstante las diversidades en el temperamento político del norte y del sur, los Estados del norte y del sur siempre se han concentrado en la democracia representativa y liberal fundada sobre las ideas de Locke y de Montesquieu y estructurada en un régimen de separación de los poderes. Salvo ciertas evoluciones, desde luego considerables, que se han producido en estos últimos años, se puede estimar que este análisis, en la época en que él fue hocho, era de una perfecta precisión.

No obstante las diversidades raciales y religiosas se puede concluir, como lo hacía Alvarez, en la existencia de un pueblo continental teniendo conciencia de marchar en un medio nuevo y en una historia común que a través de cierta unidad daba una cierta expresión a la civilización occidental.

El derecho es uno de los aspectos de esta civilización. Esta es la razón por la cual, en la Quinta Conferencia Panamericana de 1923, Alvarez destacó la solidaridad que existe entre las repúblicas americanas y estudia los elementos esenciales de la misma: el elemento sicológico. Insiste él en sus comunicaciones, en sus publicaciones, en el paralelismo de los hechos de la historia diplomática y de las mentalidades políticas de todas estas repúblicas; muestra que todas ellas han tenido las mismas tradiciones históricas y que todas han conocido los mismos peligros de parte de Europa, peligros que se materializaron en una política sistemática de intervención respecto de todas estas repúblicas mediante el uso abusivo de la protección diplomática de sus nacionales en el extranjero.

Destacaba igualmente la politica de fraternidad continental que, como consecuencia, estas repúblicas establecieron entre ellas. Desde 1889, desde la Primera Conferencia Panamericana reunida en Washington, ellas plantearon nuevas reglas: aquella de la renuncia a la guerra, aquella del no reconocimiento de las conquistas y de todo lo que pueda haber sido adquirido por la fuerza; asi tomaba forma el particularismo jurídico del continente. 
B. La originalidad juridica de este continente, que este método ha permitido inventariar y medir, surge en la obra de Alvarez puesto que fue el primero en sistematizarla. Ciertamente, antes que él, se habia ya hablado de algunas reglas que eran propias del continente americano. Hubo, entre 1880 y 1885, autores sudamericanos, poco conocidos en la hora actual, que llamaron la atención sobre ciertas normas que no se aplicaban en Europa, pero que por el contrario se encontraban en la América del Sur. Pero no eran aquéllas más que simples aproximaciones, las cuales, como sucede frecuentemente, una vez planteada la idea esperan a quien sabrá presentarlas dentro de un sistema.

Alvarez demostró en seguida que el regionalismo jurídico existía un poco en todas partes. Fundándose en el derecho del siglo XIX recuerda que en Africa existen -o existieronciertas reglas de derecho internacional, como por ejemplo en el caso de la esclavitud antes de que los Estados renunciaran a ella. Existió un régimen de zonas de influencia que las Conferencias de Berlín finalmente consolidaron. En Asia des. taca la existencia de un régimen de puerta abierta, de capitulaciones que se encontraban también en otras partes del mundo, el régimen de las concesiones. Nota así ciertos particularismos propios en determinadas regiones del mundo.

Pero en América este particularismo es mucho más acentuado. En efecto, según él, la influencia del continente ha planteado problemas y principios nuevos.

Problemas nuevos: Aquellos de la condición internacional del territorio - puesto que se trata de un país nuevo-. de la adquisición de territorios por ocupación; el principio del "uti possidetis" para la delimitación de fronteras: ha sido admitido desde el comienzo de la historia de las repúblicas independientes; la condenación del derecho de conquista, los problemas suscitados por la formación de Estados, por las secesiones, por las anexiones; Ios problemas de la nacionalidad, el reconocimiento de gobiernos en un siglo XIX y no me atrevo a decir en un siglo $\mathrm{XX}$ que permanece dentro de una 
gran inestabilidad gubernamental en América del Sur; el derecho de asilo en las legaciones, que es una consecuencia de esta inestabilidad gubernamental; y frente a todos estos problemas particulares de este continente surgen principios, algunos de los cuales son formalmente contrarios a aquellos en vigor en Europa y otros generalizan reglas apenas conocidas en Europa - pienso particularmente en el arbitraje obligatorio, o en la renuncia al uso de la fucrza, dos reglas que aparecen sin ser siempre respetadas en el normativismo continental de fines del siglo XIX, en circunstancias que todavía permanecen virtualmente ignoradas en el antiguo mundo.

En fin, una tercera categoría de principios: principios totalmente originales puesto que eran propios de los problemas del continente.

Sobre este particular Alvarez no se contenta con una simple clasificación puesto que ella sería meramente estática. El derecho internacional americano se ubica en el espacio y en el derecho internacional general del cual es una expresión americana.

Se ha hablado de panamericanismo jurídico; creo yo que más bien corresponde hablar de un derccho que se presenta como una situación americana del derecho internacional. Es lo que el propio Alvarez siempre sostuvo para tratar de rechazar el reproche que se le hacía de querer desconocer la existencia de un derecho universal. Siempre sostuvo que el derecho internacional americano no es la negación del derecho intcrnacional universal. Sin embargo siempre se le combatió con este argumento. Lo que sucede es que él no negaba el derecho internacional universal, pero sus planteamientos entraban en pugna con otro derecho, en pugna con el derecho europeo; y es aquí que aparece el dinamismo de esta doctrina que frecuentemente fue interpretada como una simple doctrina de situación de un derecho, en circunstancias que se trataba de una doctrina de reivindicación, de una doctrina de luch:. 
2. Vinculos entre el Derecho Internacional Anericano y otros sistemas

El derecho internacional americano se ubica, como se diria hoy día, en una situación dialéctica. Reivindica un particularismo tanto en relación al derecho universal como en relación al derecho europeo. $\mathrm{Y}$ esta reivindicación tiene el valor de quebrar barreras.

Para esto es necesario examinar el derecho internacional americano dentro de su significación histórica: en el interior del continente y en el exterior.

En el interior, debemos situarlo en las relaciones entre América del Sur y América del Nortc, pero lo que es esencial es situarlo bien dentro de las relaciones del continente americano, del nucvo mundo, y del antiguo mundo. El derecho internacional americano, tal como lo sostiene Alvarez, es la afirmación de que el derecho universal no es el derecho euroropeo; que si el derecho internacional americano es efectivamente contrario con frecuencia al derecho europeo ello se debe a que significa anular lo que sea contrario al derecho universal, y mediante este planteamiento él rasga el velo que recubría al derecho europeo de la reputación de universalismo. El niega que el derecho europeo sea precisamente el derecho universal; "ha dejado de serlo" dice ćl, en el momento en que lo escribe.

A. El derecho internacional americano en el sistema inleramericano, es decir, en las relaciones norte-sur. Tiene, en efecto, un valor reivindicativo en esta perspectiva norte-sur.

Alvarez enseña que el derecho internacional americano existió desde el comienzo de la Independencia y que él fue falseado por las desviaciones del monroísmo. Pretende reencontrar el sentido profundo del monroísmo que, según él, correspondía esencialmente al continentalismo. Es hoy día una tesis admitida corrientemente; se ha escrito mucho sobre el particular. Pero él fue, parece, uno de los primeros en sostenerla. 
No es del caso recordarles la doctrina de Monroe. Ustedes saben que en esta doctrina se contenía un rechazo a toda intervención de Europa, a cualquier título que ella fuese, en el nuevo mundo; pero igualmente se encuentra en potencia la idea de que los problemas americanos no podían ser resueltos sino por los Estados americanos. Estos Estados estaban por lo tanto en el interior del Nuevo Mundo, escapando a toda penetración europea, y en este interior ellos también debian encontrarse en una situación de igualdad.

Precisamente, este continentalismo de la doctrina fue desviado, deformado por la actitud de los Estados Unidos que practicaron una política deliberada de intervención en los asuntos internos de América Central y de América del Sur, intervencionismo constante cuyas manifestaciones son bien conocidas y que Alvarez fue también uno de los primeros en denunciar de una manera sistemática. El clasificó las intervenciones del Gobicrno de los Estados Unidos; cn primer término expuso lo que él llama las intervenciones de hegemonía que tienden a presentar a los Estados Unidos como el "Patrón" del Continente: es la época del "big stick diplonacy" manejada por Theodore Roosevelt quien, parece, tenia la mano demasiado pesada y deseaba enseñar - siempre con sus ideas edificantes subyacentes bastante marcadas de puritanismo"la buena conducta", como él mismo la llamaba, a los países de América del Sur en sus relaciones internacionales, particularmente cn lo que respecta a aquella virtud muy apreciada en el mundo de los negocios de los Estados Unidos del respeto de la palabra empeñada y de la regularidad en la ejecución de los contratos, virtudes que en la época eran bastante poco honradas en Amćrica del Sur y que conllevaban reclamaciones de parte de los acreedores europeos, de parte de los Estados europeos que tenían la pretensión de desencadenar acciones de intervención en el continente, contra las cuales los Estados Unidos, en nombre de la doctrina Monroe, no dejaban de sublevarse. Pretendían los Estados Unidos que toda reclamación de origen europeo debía scrles presentada pri- 
mero para que, como bucn tío tutor de la América Latina, fueran ellos quienes se dirigieran a los países del sur y los pusieran en condiciones de hacer frente a sus obligaciones internacionales. Hubo entonces esta política de hegemonía, esta política del tío tutor.

Y luego hubo otra política: la política de intervención imperialista, que concluyó con la anexión de Puerto Rico, de las Filipinas u otras anexiones como aquella de Texas. En estas intervenciones imperialistas no solamente se puede ver el "big stick policy", sino también la "dollar diplomacy" $y$, como un reflejo de las fórmulas llenas de salud política de Theodore Roosevelt, se planteaba que "América del Sur tiene la forma de un jamón y el Tío Sam tiene una buena posibilidad de comérselo", acerca de lo cual se encontró un cco en aquella definición de un autor americano que escribía en 1928: "La Unión Panamericana es el Ministerio de Colonias Americano".

Alvarez había denunciado todo esto, y lo había denunciado como una desviación, como un desconocimiento del espíritu del mensaje. Yo no sé si siempre tuvo razón de dibujar un retrato tan clogioso de Monroe como un gran continentalista digno de Bolívar, pero es un hecho que la doctrina de Monroe fue históricamente muy bien recibida en América Latina y numerosos fueron los hombres de Estado que la invocaron en diversas ocasiones. Es precisamente esta intervención de los Estados Unidos que rompía el significado de la primera.

Los trabajos de Alvarez tuvieron en todos los medios político-jurídicos del Nuevo Mundo una gran repercusión puesto que se adelantaban a las reivindicaciones y a las múltiples impaciencias a las cuales su obra aportaba una traducción, una expresión científica y técnica. $Y$ es a este título que él pudo jugar un rol muy importante en este movimiento que concluyó con la continentalización de la Doctrina de Monroe.

Ya la reclamaba a partir de 1917. Entonces habia presentado un proyecto de convención que declaraba que todos los 
Estados americanos son solidarios en cuanto a la defensa y a la mantención de sus derechos, "solidarios en la defensa y en la mantención de sus derechos", lo que significaba que ya no correspondía sólo a los Estados Unidos el aparecer como el campeón del continente y de encargarse del destino de la América del Sur, sino que cuando un problema fundamental interesaba a la paz del continente, la integridad territorial o la independencia política de uno de estos Estados, es el conjunto de Estados del Nuevo Mundo que debían en común, en el curso de una consulta, estudiar las medidas a tomar para hacer frente a la situación.

Esta contincntalización de la Doctrina de Monroe sería en efecto adoptada dentro del sistema interamericano en 1936 en la Conferencia Panamericana de Buenos Aires, después de la asunción del poder en Estados Unidos del Presidente Franklin Delano Roosevelt y la instauración de una política interamericana completamente diferente, la política de "buena vecindad".

No resulta de más destacar el rol determinante que Alvarez jugó en esta ocasión al preparar las vías para el regreso a las fuentes de un continentalismo auténtico. Asi como él trabajó por la instauración de un sistema regional fundado sobre la igualdad en lugar $\mathrm{y}$ en reemplazo de un sistema fundado sobre la hegemonía yanqui, de la misma manera se planteaba el problema de las relaciones de este mundo con el antiguo; y entonces, dentro de esta segunda perspectiva, no cesaba é de sostener que el derecho internacional americano era una reivindicación de autonomía jurídica respecto de un derccho curopeo falsamente calificado hasta entonces como el derecho universal.

B. El Derecho Intemacional Americano como reivindicación de autonomia juridica. El derecho internacional americano, reivindicación de una autonomía jurídica contra el absolutismo del derecho universal, correspondía admirablemente a todo un movimiento de pensadores que, contando a Alvarez entre otros, se aproximaba al movimiento liberal, hostil 
a todos los absolutismos. Pero no olvidemos que se trataba de una actitud tipicamente continentalista. Los americanos de! norte y del sur son originariamente secesionistas que han conquistado su libertad contra Europa, históricamente, primitivamentc, me atrevo a decir.

Es la misma rcclamación de independencia que se enctentra en esta tesis del derecho internacional americano.

Es Ja expresión de un anticolonialismo jurídico. Ello se debia particularmente a que el derecho universal de la época era, según nuestro autor, nada más que un derecho europco. EI régimen colonial había hecho de la vida internacional americana hasta el comienzo del siglo XIX una prolongación y un complemento de la vida europea. Pero luego de la conquista de su independencia por estas repúblicas, el medio permitiría desarrollar su potencial de juridicidad hasta entonces detenido por la colonización. De esta manera aparecen las relaciones entre la libertad y cl derecho. Es menester dejar que se produzcan los efectos naturales, dcjar hacer, dejar pasar los efectos de la naturaleza. Bien les decía que de esta manera se remontan a las ideas de los filósofos del siglo XVIII. Se trataba entonces de reaccionar contra un derecho universal que no era en realidad más que un derecho europeo proyectado en América c impuesto a América. El pretendido derecho universal era entonces un derecho antiguo, derecho de la época en que no había Estados independientes en América ni agenics creadores de Derecho Internacional.

Pueden ustedes apreciar cómo todo cste continentalismo desemboca en la noción de un derecho nuevo, derecho nuevo no solamente en el plano regional sino también en el plano universal. Puesto que se trata siempre del mismo problema: no es la negación del derecho universal, es la buisqueda de un nuevo derecho universal que no será construido precisamente -y que no será posible - sino luego de que se haya podido estudiar cada uno de los derechos continentales; solamente en ese momento se estará en condiciones de iniciar una sistematización de los principios comunes al conjunto de estos 
derechos continentales. Pero previamente debe comenzarse por una investigación de los derechos continentales antes de poder acceder al derecho universal.

El derecho americano no era la negación del derecho universal; era solamente la negación del derecho europeo y desembocaba en la investigación de un derecho internaciona! nuevo, es decir en la segunda actitud de la vida cientifica de Alvarez, en su actitud presente, aquella a la cual actualnente él asigna la más grande importancia. De esta manera, este continentalismo reivindicativo, lejos de replegarse sobre sí mismo, se ensamblaba con toda naturalidad en el universalismo en búsqueda de un nuevo derecho internacional.

Alvarez realizó la sintesis tanto en el espacio como en el tiempo del regionalismo y del universalismo de una parte, del derccho clásico y del derecho nuevo por otra parte. Observador de la vida internacional, no se contentó con estudiar el derecho existente, sino también las reglas en formación, descubriendo su aparición en una u otra ocasión y, partiendo de la base de las profundas transformaciones de la colectividad internacional, él subraya las transformaciones del derecho que las rige.

Además de haber procurado demostrarles cómo este continentalismo reivindicativo, esencialmente americano, anticolonialista, desembocaba en un universalismo que rechazaba al derecho europeo la calificación de derecho universal y que pretendía que el derecho universal verdadero sería el punto de convergencia de todos los derechos continentales, debo agregarles que sobre tales planteamientos Alvarez se oricntaba directamente hacia la noción de un nuevo derecho. El derecho universal, tradicionalmente así calificado, no era más que un derecho europeo antiguo, en circunstancias que el nuevo derecho era el derecho que surgía luego del desmembramiento de Europa y la creación de una colectividad internacional todavía en plena evolución.

Es por esta razón que si deseamos ensayar comprender lo que Alvarez entendía por Nuevo Derecho Internacional, es 
menester evidentemente referirse a sus opiniones disidentes que hasta el presente son la fuente donde se encuentra más fácilmente la exposición de su doctrina. Existe un voluminoso libro en preparación que Alvarez todavía no ha concluido y que se llama precisamente "EI Nuevo Derecho Internacional". El autor espera que él aparezca a fines del presente año; por el momento estamos obligados a referirnos a sus opiniones individuales o disidentes y a algunas obras que él publicó en estos últimos años después de la segunda guerra mundial, o en los años que la precedieron, particularmente "La psychologie des peuples et la reconstruction du Droit International", publicada cn París en 1936, o "La Renovación del Derecho Internacional", publicada en 1945 en español en Buenos Aires.

En medio de estas obras dispersas, que no nos ofrecen todavía esa imagen de conjunto de una doctrina que a primera vista pareciera contener algunas veces ciertas contradicciones, nos es difícil encontrar nuestro "fil d'Ariane".

Creo que es necesario hacer lo que él mismo hizo, es decir, tomar conciencia desde luego de los trastornos que han afec. tado a la colectividad internacional. $Y$ solamente en seguida podremos estar en condiciones de medir las modificaciones consecuentes del Derecho Internacional. Tales son las dos partes que van a guiarnos a partir de este momento. 


\title{
LOS TRASTORNOS DE LA
}

\author{
COLECTIVIDAD INTERNACIONAL
}

Desde el punto de vista de Alvarez la colectividad internacional no solamente ha sufrido la evolución que numerosos autores han sabido describir. Para él, no se trata de una evolución sino más bien de una revolución. La diferencia es fundamental porque ustedes saben que las revoluciones tienen un efecto derogatorio sobre las reglas jurídicas y políticas anteriores.

El pretender que las modificaciones de la colectividad internacional alcanzan la importancia de una revolución significa que el conjunto de los problemas jurídicos debe ser retomado comenzando la mayoría de las veces desde cero. Es una actitud muy singular y Alvarez no acepta la discusión sobre este punto. Sólo se puede discutir con él si de antemano se acepta que la solución debe ser revolucionaria.

(Es desde luego el momento de rendir homenaje a un hombre que ha alcanzado su edad y quien, en la cúspide de su carrera científica, recién nos dice: "Todo el derecho internacional clásico debe ser reformulado totalmente de punta a cabo". Es raro ver en hombres de esta edad manifestar un conservantismo tan escaso, incluso en el plano científico).

¿De qué manera esta colcctividad internacional ha sido trastornada? Si nosotros ensayamos de recopilar y de sintetizar las observaciones de nuestro autor, parece que ella lo ha sido desde tres puntos de vista: En primer lugar en sus dimensiones y en su centro de gravedad, en seguida en su naturaleza y en su espíritu, y finalmente en sus medios de expresión y acción. 
A. La colectividad internacional ha sufrido trastornos en sus dimensiones $y$ en sus centros de gravedad

En lo que respecta a sus dimensiones no es este un punto difícil de comprender. El mundo se ha vuelto pequeño. Ello es bien conocido y un americano, Wendel Wilkic, quien fue candidato a la presidencia de los Estados Unidos contra Roosevelt, luego de haber realizado en 1944 una gira de propaganda por el mundo, escribía una obra quc para t́l representaba la expresión de una "revelación": "El mundo es uno".

Es paradojal observar que para ir de un lugar a otro un correo tomaba aproximadamente el mismo ticmpo que un correo de Julio César. Después de siglos de inmovilidad hay ahora una extraordinaria aceleración, no solamente de los hombres y de las cosas, sino también de Ios acontecimientos $\mathrm{y}$ de la historia.

La anterior es una obscrvación banal pero quizás todavía no se han deducido todas las consecuencias que ella tiene en el orden internacional. Al transformarse cl mundo en algo mucho más pequeño, como consecuencia del progreso técnico, de los medios de transporte, de los medios de comunicación, los hombres, los bienes y sobre todo las ideas - no se olvide que Alvarez es considerado el Jefo de la Escuela Sicológica del Derecho Internacional - están hoy día en contacto, y sus dimensiones espirituales han sido también modificadas.

Desde un punto de vista material el mundo es hoy día más restringido. Pero desde un punto de vista espiritual, por el contrario, parece haberse enriquecido singularmente.

En su aspecto material hay una mayor restricción pues el progreso técnico ha permitido múltiples intercambios, una interdependencia creciente entre los pueblos y nuevas necesidades que no pueden ya ser satisfechas en el marco racional; los hombres han llegado a ser interdependientes los unos de los otros de la misma manera como son unidos dentro de un mismo destino aquellos que afrontan una misma tempestad sobre un mismo navío - imagen bien conocida-. De ahora 
en adelante siendo el mundo "uno" de manera efectiva, las elecciones presidenciales en los Estados Unidos, la guerra en el Extremo Oriente o cambios en el personal dirigente de $\mathbf{R u}-$ sia Soviética, constituyen acontecimientos que afectan profundamente a los individuos conscientes del resto del planeta.

Conocemos las fórmulas de Valery. En su tiempo - mucho antes de que el fenómeno alcanzara toda su amplitudtambién él había denunciado este acercamiento y esta investigación total del mundo: "Toda la tierra habitable -escribia - ha sido en nuestros días reconocida, inventariada, dividida entre las naciones; la era de los terrenos vacíos, de los territorios libres, de los lugares que no pertenecen a ninguna persona, luego, la era de una libre expansión, está concluida; ya no hay más Europa que no lleve una bandera, no hay vacios sobre el mapa, no hay regiones fuera de las aduanas, fuera de las leyes, ya no hay tribus cuyos asuntos no hayan sido materia de alguna carpeta y que no dependan, por la desgracia de la escritura, de varios humanistas lejanos en sus escritorios. "El tiempo del mundo que ha terminado comienza". La frase es célebre. Ella corresponde muy fielmente a las observaciones de Alvarez.

\section{El Derecho Internacional clásico}

Pero, para él, así como el mundo ha sido afectado en sus dimensiones igualmente lo ha sido en su centro de gravedad. El origen de la sociedad internacional es Europa. "El derecho internacional clásico - dice él sustancialmente- es un derecho intereuropeo". Grotius solamente se preocupó de las relaciones europeas (¿cómo podría ser sino de esta manera?); no había entonces un derecho internacional de escala mundial, planetaria, en circunstancias que en el momento presente en que les hablo se estudia el establecimiento de un derecho interplanetario. Sólo recientemente se ha visto el establecimiento de un verdadero derecho internacional; $y$, precisa- 
mente, todavía no se conoce bien este derecho internacional; de ahí que él sea nuevo. El derecho internacional que se conoce es el derecho de los europeos tal como fue descrito por Grotius, Vattel, Pufendorf; también hubo rusos que lo describieron, pero estos rusos de la ćpoca pertenecían a una Rusia que reivindicaba su incorporación al concierto europeo; hubo un De Martens; pero el derecho internacional no era más que el reflejo de una sociedad europea y de las relaciones intraeuropeas.

Y, precisamente, fuc en Europa que nacieron y se desarrollaron aquellos progresos técnicos, este acercamiento del mundo, esta civilización industrial. Y fueron los europeos quienes llevaron a otros lugares esta forma de industrialización, de expansionismo, sus luchas por los mercados exteriores y sus guerras - puede pensarse cn la frase de Jaures sobre el capitalismo que conileva la guerra como la nubc conlleva la tempestad. Ignoro si acaso es cierto, pero los acontecimientos están ahí; y las guerras acarrean finalmente la realización de las profecias que Alexis de Tocqueville habia hecho en 1841 cuando recién terminaba de escribir: "La Libertad, la democracia en América", profecía según la cual el siglo XX sería el siglo de los Estados Unidos y de Rusia. Esta profecía también había sido compartida en la desesperación y el sujcidio por Prevost-Paradol quien, conociendo en 1870 que Francia y Alemania entraban en guerra la una contra la otra, se dio muerte porque veía en esta guerra, que estimaba fratricida, el primer signo de la muerte de Europa.

La misma profecía se encuentra en las cartas de Renán al Doctor Strauss donde le expone que Alemania comete un error al reivindicar Alsacia y Lorena, porque al hacerlo ella desencadenaría un conflicto que bien duraría cien años, dice él, entre Francia y Alemania; y Francia no tendría otro recurso que apoyarse en los eslavos para destruir a los alemanes y, finalmente, se llegaría a la dominación de los alemanes por los rusos (y, en 1945, bien podía pensarse en el momento en que Joukoff estaba en Berlín que las predicciones de Renán 
resultaban en cierta medida verificadas). Ello también rememora los propósitos de Víctor Hugo cuando, en su discurso de $1^{\circ}$ de marzo de 1871 en la Asamblea Nacional, denunciaba el Tratado de Paz en preparación y la cesión de Alsacia y Lorena: "Si esta paz inexorable se concluye, se terminará el reposo de Europa. El inmenso insomnio del mundo va a comenzar". Todavía dura.

\section{Las necesidades de renovación}

Todos estos fenómenos llegan hasta 1939 que para Alvarez es un año crucial. Es para él la fecha fundamental. Ya después de la primera guerra mundial él habia propuesto adaptaciones del derecho internacional; ya en 1916 él publicaba en Washington "Le Droit International de l'Avenir", estimando que después de la primera guerra mundial resultaba obligatorio introducir en el derecho internacional un cierto número de modificaciones.

Pero después de 1939 estima que ya no se trata de simples modificaciones; es menester establecer nuevas reglas del nuevo derecho.

Ustedes conocen las consecuencias de este declinar de Europa; no solamente dos mesianismos que se confrontan: el mesianismo soviético y el mesianismo de la American way of life. Frente a la expansión de la ideología marxista leninista el continentalismo americano - lo que se llama el aislacionismo- debía concluir por transformarse también en mesianismo. Esta transformación en mesianismo resultaba tanto más fácil puesto que el aislacionismo había constituido para los Estados Unidos en cierta medida una actitud religiosa, y esta reivindicación de puridad que les había llevado a replegarse sobre ellos mismos durante todo el siglo XIX y una parte del siglo XX debía, desde el momento en que el mundo se había transformado en demasiado pequeño y en que sus centros de gravedad se habían desplazado, ceder su lugar a una 
actitud que permitiera satisfacer de la misma manera los imperativos morales; siendo el repliegue insuficiente para defender el capital moral del cual América se cree depositaria, era menester afrontar abiertamente al comunismo después del nazismo, y el aislacionismo transformarse en un mesianismo

Mesianismo de los Estados Unidos, mesianismo soviético, y en el fondo de su confrontación, las presas que deben tomar, es decir, los países subdesarrollados, aquellos que todavía no han realizado su opción. Europa ha hecho sus opciones, pero los pueblos subdesarrollados constituyen todavía un campo que podria, en el plano del derecho internacional en cierta medida, asemejarse a aquel de la alta mar (de la alta mar del tiempo de Grotius en la época en que todavía no existían plataformas continentales de 200 ó 300 millas). Se decía que la alta mar era una "res nullius" o que ella era un "res communis"; no le pertenecía a nadie y sí a todo el mundo. Los pueblos subdesarrollados se encuentran en una situación similar y esa es precisamente la razón por la cual ellos son objeto de tantas solicitaciones tan urgentes. Su deseo es pertenecer a ellos mismos, y Bandung es precisamente una protesta de una personalidad y de una autonornía entre los dos bloques. Pero Alvarez había previsto, también Bandung, puesto que su reivindicación en contra de la asimilación abusiva del derecho europeo al derecho internacional universal era precisamente una protesta en contra de lo que le parecía una usurpación.

La reivindicación de los derechos regionales es uno de los aspectos del movimiento de Bandung que planteó un cierto número de principios que han sido reiterados en la Conferencia de El Cairo, recientemente celebrada, principios de coexistencia pacífica que en sí mismos surgen como principios de un derecho nuevo (1).

(1) Véase "Les cínq principes" de coexistence et lo droit international". L. Foscaneanu. Annuaire Français de Droit International, 1956, págs. 150-180. 
De esta manera trabajan en el mundo nuevas mentalida. des políticas que aspiran a participar en el Derecho Internacional como actores y no solamente como destinatarios; tal es el sentido del movimiento del nuevo derecho internacional. Estos pueblos participaban hasta entonces del derecho internacional, pero como destinatarios de un derecho europeo proyectado al exterior; desean por el contrario ahora participar como actores en la elaboración del derecho internacional universal. De ahí los equivocos y las incomprensiones que oponen a los antiguos Estados respecto de los nuevos y una de cuyas ilustraciones es el asunto del Canal de Suez.

Del Regionalismo al Internacionalismo, al Universalismo, hay un paso considerable que ustedes ven porque él tiene el significado de una revolución. Es este fenómeno el que Alvarez habia presentido desde hacia mucho tiempo. Y en el momento presente resulta evidente que los acontecimientos le han dado la razón sobre este punto.

El mundo continúa trabajando. Ello nos explica entonces fácilmente por qué él se modifica, no solamente en sus dimensiones y en su centro de gravedad, sino también en un alcance más profundo de su naturaleza y de su espíritu.

B. El mundo es afectado en su naturaleza y en su espiritu

El mundo ha sido afectado en su naturaleza y en su espíritu pues la morfología de la sociedad internacional nos demuestra que ella no tiene ningún punto de relación con la sociedad-Estado del siglo XIX.

\section{La sociedad de Estados}

La colectividad internacional es todavía hoy día una sociedad de Estados; el Estado surge como soberano, reivin- 
dicativo, replegado sobre él mismo. (Si ustedes me permiten esta imagen, el Estado aparece más cercano de un fenómeno existencial que de un fenómeno esencial). Lo propio del derecho es situarse al nivel de la esencia, de lo general, de lo abstracto. Lo propio del individuo es por el contrario considerarse en su propia existencia, en su propia condición, en su propia situación. "El hombre cstá localizado", frase ésta de Sartre que no ha perdido su lugar en esta exposición de derecho internacional; el hombre está localizado en una cierta existencia y, aun cuando él se encuentre participando en una historia común con muchos otros hombres, tiene el sentimiento de no percibir los defectos de esta historia sino a través de él mismo y de interpretarla en su propia existencia personal. El existencialismo es precisamente una filosofía que es hostil a todo sistema y especialmente a todo sistema histórico.

Los Estados practican el existencialismo sin saberlo. No fue Alvarez quien lo dijo, pero utilizó estas imágenes simplemente para subrayar el fenómeno. Los Estados practican el existencialismo; esta es la razón por la cual yo creo que Vatell - De Martens son los auténticos padres del existencialismo jurídico. Practican el existencialismo en el sentido de que cada uno desarrolla una historia deseando sobre todo, si acaso no exclusivamente, considerarla como personal. El interés que persigue es el propio. Es por cllo que tradicionalmente rechazan el adherir a una regla general, válida para todos, y constantemente cuestionan la validez del derecho escrito o incluso consuetudinario. Tal es la sociedad internacional clásica fundada sobre la autonomía de la voluntad estatal.

Toda evolución de la sociedad internacional hacia formas de cooperación, hacia formas de organización internacional, supone una transición. La transición de la idea de que cada Estado construye su propia existencia, de su carácter exclusivo, a aquella de la aceptación de un hecho que puede finalmente, bajo la presión de la historia, llevarlo a aceptar el hecho de que otros Estados son igualmente afectados de la mis. ma manera por la historia, y se encuentran por tanto frente 
a él en una situación de coexistencia, en el sentido estricto de Ia palabra. Tal es la verdadera orientación de la coexistencia pacífica, que supone una toma de conciencia de una identidad de destino, al menos respecto de un determinado número de puntos.

La sociedad internacional ha sufido trastornaciones tan profundas que, precisamente, ello hace que hoy dia aparezca ya no más con un aspecto o en un contexto estrictamente interestatal. Existen las organizaciones internacionales -cabe contar más de mil si se suman las organizaciones gubernamentales y las organizaciones no gubernamentales-, hay grupos sociales, sindicatos, asociaciones, inclusive individuos que buscan expresarse en el plano internacional. La compartimentalización del mundo ya no es más exclusivamente estatal.

Las transformaciones provicnen precisamente del hecho de que la colectividad internacional ya no es una simple yuxtaposición de Estados. Pueden ya apreciarse fenómenos de relaciones internacionales que trascienden a los gobiernos, ya sea en el plano de las organizaciones supraestatales -como se puede constatar en las organizaciones de la pequeña Europa, a la vez localizada y especializada-, ya sea al margen de las organizaciones internacionales de una manera natural.

La sicología de los pueblos

Resulta, en efecto, que la sicología de los pueblos juega un rol creciente.

Ustedes saben que Alvarez es considerado jefe de la Escuela Sicológica. Preciso: jefe de la Escuela del Objetivismo Sicológico, en el sentido de que él estima que las bases sicológicas son bases objetivas que es menester estudiar en sí mismas, sin un espíritu apriorístico y cualquiera que sea el agrado o el desagrado que pueda tenerse al confrontar en un examen las sicologias de pueblos tan diversos, cualquiera que sea la decepción que se pucda tener respecto de la impresión 
de un mundo separado que previamente se lc creía reunido en un derecho universalista.

Esta sicología alcanza las relaciones internacionales, pues antiguamente el derecho llamado internacional no merecía exactamente este calificativo. Recientemente les expresé que no era plenamente internacional, puesto que él no era sino un derecho europeo y no un derecho mundial, pero tampoco lo era desde el punto de vista de que se trataba de un derecho intergubernamental, un derecho interdiplomático. Las naciones no jugaban prácticamente ningún rol. El derecho sólo tiene verdaderamente el sentido preciso de la palabra "internacional" si acaso las naciones participan, ya sea que se crea que éste es un principio: el principio de las nacionalidades, del cual se deduce el derecho de los pueblos a autodeterminarse -momento en cl cual el derecho se vincula con la nación pero para ello es necesario esperar el fin del siglo XIX-; ya sea que se estime que se trata de una etapa superior de la organización internacional, en la cual se vislumbre la constitución de asambleas en las que se encuentren representantes nacionales, parlamentos de Estados - asambleas del tipo de aquellas que se encuentran en Estrasburgo o en el cuadro de la Comunidad europea, que son asambleas internacionales en el sentido estricto de la expresión, en circunstancias que la Asamblea de las Naciones Unidas todavía en el momento presente no es a estc respecto una asamblea internacional sino más bien constituye una asamblea intergubernamental, interdiplomática.

En tiempos anteriores la sociedad internacional era una sociedad interdiplomática. En cambio hoy día la sicología de los pueblos juega un rol determinante allí donde anteriormente intervenía sobre todo la acción de los diplomáticos. La acción de los diplomáticos se desarrollaba en el silencio hermético de Jas Cancillerías: era Ja ćpoca de la diplomacia secreta.

Cuando el Presidente Wilson, después de la primera guerra mundial, recogió las banderas de un americano virtuoso 
y hombre de derecho, enseñaba que era menester sustituir las relaciones de fuerza por las relaciones juridicas entre los Estados, deseando imponer el reinado de la ley, es decir, el reinado de una norma que dispusiese de una manera abstracta y general para determinadas categorías y no más para sujetos considerados en su existencia individual. Cuando deseó llevar esto a la práctica se encontró con muchísima oposición, y desde luego la oposición de su propio Senado. Pero al mismo tiempo y por vía de consecuencias estaba obligado a abrir las ventanas y puertas de las cancillerías y a establecer el principio de la diplomacia pública.

Esta diplomacia pública exponía a los pueblos a todas las propagandas. Ciertamente también abría la propaganda a los pueblos. Sin embargo pareciera ser que fue un movimiento inverso el que se produjo. El principio democrático se satisface ampliamente mediante el homenaje rendido a la soberanía popular; en seguida basta, mediante un aparato de propaganda bien concebido, captar esta soberania popular y dirigirla en el sentido del poder.

Pero siendo la sociedad internacional un conjunto de poderes dispersos y no concentrados, poderes dispersos entre una centena de Estados, es la propaganda la que rasga la colectividad internacional. Propagandas internas, propagandas externas, cuyo entrecruzamiento es extraordinario pues todos estamos sujetos y somos destinatarios de las propagandas de nucstro país y de aquellas de otros países. Este era un hecho que los diplomáticos del siglo XIX prácticamente no necesitaban considerar.

La interdependencia internacional.

En fin, cn tercer lugar - y es la consecuencia de este acontecimiento--, siendo el mundo demasiado pequeño y desgarrado por las propagandas que se disputan una opinión pública hoy día mundial -pues existe hoy día una opinión pública mundial-, 
los hombres cstán en una situación de interdependencia. Alvarez estima que la colectividad internacional actual no es más una simple colectividad, sino una verdadera sociedad, un conjunto en que todos los miembros son interdependientes pero sin que ello signifique que se deba creer que los problemas han sido resueltos, sin que la constatación de esta interdependencia invite al optimismo. Lejos de ello. Valery también decía: "Antiguamente, toda política especulaba sobre el aislamiento de los acontecimientos"; es precisamente este aislamiento de los acontecimientos que es tan difícil de proteger en la hora actual.

Todo optimismo sería prematuro; la interdependencia indudable entre los pueblos ciertamente debiera permitir la instauración de una cierta unidad, inconcebible sin ella; pero una tal evolución no puede ser sino lenta. $\mathrm{X}$, en lo inmediato. esta interdependencia produce el efecto, en una sociedad de pueblos objeto de corrientes contrarias, de desatar una dramática crisis de crecimiento. El mundo tiene la impresión de estar compuesto de gentes que se encuentran "Ios unos sobre los otros"; la interdependencia entre los hombres no constituye el anuncio de una paz en lo inmediato, es por el contrario el anuncio de todos los conflictos de la convivencia, de todos los conflictos nacidos de la promiscuidad.

A este respecto las observaciones de Alvarez, muy realistas, lo alejan un tanto de una parte de la doctrina contemporánea, particularmente de la escuela sociológica, solidarista, que vc en la interdependencia el signo evidente de una marcha del mundo hacia la unidad. Alvarez no niega que esta marcha haya ya comenzado; pero Ilama la atención sobre los múltiples obstáculos que todavía encuentra (2).

(2) Debe consiclerarse a este respecto el contrasentido que comete el señor William Samore en uri urticulo bastante severo sobre "The New lnternational Law of Alcjandro Alvarez", publicado en el "American Journal of Internutional Law" (Voltmen 52, Enero de 1958). EI nícga la interdependencia, pues la considera incompratible con el recrudecimiento de los nacionalismos. Confunde de esta manera interdepen. dencia, solidaridad y fraternidad, en circunstancias que para Alvarez la interde. 
Es un caminar difícil. Los progresos técnicos que transforman al mundo en una entidad más estrecha y a sus partes más interdependientes, imponen acercamientos políticos, económicos, hacen de la cooperación internacional una necesidad vital -efectivamente todas las organizaciones internacionales gubernamentales y no gubernamentales que existen traducen bien estas necesidades y este esfuerzo-, pero la marcha es sin duda ardua. Antes de llegar a algún resultado el mundo atraviesa por conflictos más desastrosos que nunca, precisamente como consecuencia de la mayor proximidad de los hombres entre ellos.

Las guerras mundiales han sido el signo de una interdependencia. $Y$ esta interdependencia es por el momento esencialmente material, económica, y va clla contra la corriente de la naturaleza profunda de la sociedad internacional.

Dicho de otro modo, el mundo no tiene más que un pueblo, pero éste está siempre poblado de extranjeros.

En fin, siendo el mundo más pequeño, sus partes componentes son más interdependientes, pero también las afecta más gravemente las divergencias que separan a las diversas familias internacionales; están en el corazón mismo del drama contemporáneo, y no hay que extrañarse entonces que él atraviese la misma crisis en sus medios de expresión y en sus medios de acción.

pendencia es un fenómeno social objetivo que resulta de los trastornos del mundo y en modo alguno, como lo cree su detractor errúneamente. constituye un sentimiento que empujaria a los pueblos a su acercamiento. La interdependencia embarca a los hombres en la misma aventura planetaria, a pesar de ellos. Es precjsamente porque esta interdependencia social no va acompañada de una fraternidad comparable que el mundo, que acerca a los pueblos hoy ojia mattrialmente sin unirlos espiritual y afectivamente. esta desgarrado como jamás to había estado antes. Interdependencia y nacionalismo van de la mano, lo que explica el drajna de nutstro tiempo. Por otra parte, la noción de solidaridad para Alvarez se distingue de aquella de la interdependencia. La solidaridad precede de un sentimiento comts aquel que une los pueblos de América Latina. 
La fuente del derecho es para Alvarez la conciencia jurídica de los pucblos. A este respecto se acerca a la Escuela SoIidarista, habiendo recién indicado que también en cierto modo discrepa de ella, escuela que insiste en la importancia de la ética. Toda la doctrina de Georges Scclle, por ejemplo, está fundada sobre la demostración que el derecho se encuentra en la conjugación de la ética y del poder; la ética es un cierto sentimiento del bien y del mal, de lo útil y de lo inútil, de lo cómodo y de lo incómodo, que concluye por expresarse en una mentalidad que es todavía metajurídica y el poder, si desea durar, tiene por misión traducirlas en reglas de derecho $-\mathrm{y}$ desea durar, porque las reglas de derecho que están conformes a la ética son aquellas que tienen una garantía de ser respetadas.

Pero esta ética es para Alvarez, en el momento presente, una cosa singularmente mutable. Ella cambia tanto en el interior de los Estados como en el exterior. Existe una movilidad de situaciones político-jurídicas y es esta movilidad la que suscita un orden nuevo.

Esta expresión de orden nuevo Alvarez la explica y la justifica puesto que en diversas ocasiones le ha significado críticas. El habla de orden nuevo, de derccho nacional nuevo, de derecho internacional nuevo. Para él, todo orden nuevo resulta de los cambios en los diversos órdenes de la actividad de un país o de varios países luego de acontecimientos catastróficos, de cataclismos sociales. El recuerda que en Francia, después de la revolución de 1789, un nuevo orden fue creado, es decir, que grandes cambios tuvieron lugar en la vida política y económica, así como en el derecho y en las relaciones internacionales. "El orden nuevo, revela él, estaba comparado con un cierto desprecio con el orden antiguo, hasta cl momento en que, a partir de un ticmpo determinado, el proceso sicológico se invierte y es el orden antiguo el cual es considerado con el desprecio que de antemano afectaba al orden nue- 
vo". Igualmente, cuando se le han hecho algunos reproches por su excesivo gusto de lo nuevo, él responde que no hay más que esperar: el tiempo trabaja en favor del orden nuevo. Cuando este último surge - agrega todavía- ello no significa que todos los elementos del antiguo orden hayan desaparecido; algunos solamente han sufrido modificaciones, más o menos importantes, particularmente en el espíritu que anima las normas del orden nuevo. (Después de la Guerra de 1914 un orden nuevo se instauró en Rusia; otro se instauró en los paises de Extremo Oriente que han adoptado, de manera casi repentina, instituciones políticas que hasta entonces ignoraban y una vida económica e internacional en la cual hasta entonces poco se habían mezclado).

Después de 1939 igualmente un orden nuevo se ha establecido prácticamente en todos los países de Europa, de Asia, de Africa, de Oceanía, así como de América.

Me atreveria a decir que hay en esta evolución una constante: siempre llega el momento en que surge el orden nuevo.

Surge en el derecho nacional. El nuevo derecho nacional evoca la creación por ejemplo de un derecho público al lado de un derecho privado, que es de reciente fecha. $Y$ nadie ha negado la existencia del derecho público porque él sea menos antiguo que el derecho privado, pues al menos se ha tomado conciencia más recientemente de la autonomía del derecho público en relación al derecho privado.

Nos encontramos entonces simplemente en el corazón de movimientos diversos, contradictorios, entre los órdenes nuevos y los órdenes antiguos. Los nuevos no suprimen la totalidad de los antiguos. Existe por tanto un momento en que todavía se mantienen muchos rasgos que surgen del antiguo orden, y de numerosos otros rasgos que anuncian la llegada del nuevo. Es allí que se produce el contacto doloroso, la tensión. Y en este momento nos encontramos en una situación que es de transición. Hay ciertos rasgos del derecho internacional clásico que todavía existen porque responden a una sobrevivencia; también los hay nuevos y sobre cuya existencia 
no se puede tener la menor duda. Pero hay una zona intermedia de interferencias reciprocas entre los principios antiguos sobre los nuevos y de los nuevos sobre los antiguos. Esta es la zona de incertidumbre del derecho internacional contemporáneo. En el desarrollo de este curso tendremos oportunidad de compenetrarnos en ambas zonas, como asimismo en la zona de incertidumbre. Nos dirigiremos tomando a Alvarez como guía pero debo confesarles que la ruta es difícil a seguir $y$, en numerosos puntos, tendremos oportunidad de ver que las opiniones disidentes que Alvarez sostuvo en la Corte de La Haya durante los diez años que han pasado, constituyen el punto de una situación que es esencialmente transitoria. Esto es lo que él explica al clasificar de acuerdo a cuatro categorías el nuevo derecho internacional.

Diversas acepciones del nuevo derecho internacional

Hay, scgún él, cuatro acepciones posibles para el nuevo derecho internacional:

a) Puede tomarse la palabra en un primer sentido: se trata simplemente de modificaciones que el derecho clásico ha sufrido en ciertas materias. Es así como el Instituto de Altos Estudios Internacionales de la Universidad de París cuando se reorganizó después de la Segunda Guerra Mundial incorporó, entre los objetivos que le fueron dados, la indicación de que las relaciones interestatales revisten aspectos cada día más complejos y variables, que encontramos después de cierto tiempo en plena evolución en la vida social y jurídica de los pucblos. "En la crisis del derecho de gentes, acrecentado por el fracaso de las sociedades de naciones y la Segunda Guerra Mundial, muchos principios han sido derogados o modificados, y hay otros que no corresponden más a las condiciones de la vida dentro de los Estados, ni a los sentimientos de tal o cual pueblo, y han sido desacreditados o violados; 
es entonces necesario reconstruir el derecho de gentes teniendo en cuenta los errores cometidos, las experiencias adquiridas de someter la concepción de base a una crítica rigurosa y de extraer las consecuencias adaptadas a las nuevas condiciones de la vida de las naciones". Estos objetivos, tal como habían existido formulados por Monsieur Sibert en esa época decisiva, coincidian de una manera muy indicativa con las preocupaciones de Alvarez, el mismo cofundador de este establecimiento. Pero no es éste más que uno de los sentidos del derecho internacional: modificación al Derecho Internacional clásico.

b) Hay un segundo sentido. En esta segunda acepción se trata de la concepción de un derecho internacional esta vez enteramente diferente y distinto del antiguo, una concepción original.

Es por ejemplo la concepción del derecho internacional soviético. Los juristas soviéticos de la hora presente no se sitúan en la línea de Federico de Martens, quien era un jurista europeo.

c) En una tercera acepción significa ciertos grandes principios establecidos por los paises de un continente que ejercen una influencia considerable sobre el derecho tradicional: es una influencia local sobre el derccho general.

Se ha visto por ejemplo el caso con la norma del arbitraje obligatorio o la regla de la renuncia al uso de la fuerza planteada primeramente en el continente americano y proyectada en seguida en cl derecho internacional general con el artículo 2 No 4 de la Carta de las Naciones Unidas.

d) En fin, dentro de una cuarta noción, la expresión Nuevo Derecho Internacional diseña los cambios profundos, revolucionarios, sufridos por el conjunto del derecho universal en sus bases fundamentales, en su espíritu, en sus instituciones. $\mathrm{Y}$ es ese trastorno del conjunto, revolucionario, del derecho universal el que Alvarez estudia y que nosotros vamos a estudiar con él en las clases siguientes. 
De esta manera las modificaciones de la colectividad internacional, en lo que respecta a sus medios de expresión y de acción, se traducen en la aparición de un nuevo orden. Este no hace más que responder a una nueva infraestructura material y mental.

Sobre la base de esta observación, no cabria cxtrañarse de ver que Alvarez adopta un método propio desde sus inicios, cuando escribía en 1910 "El Derecho Internacional Americano". Entonces, antes de llegar a la conclusión de la existencia de un particularismo jurídico del continente, había comenzado la investigación de los elementos de base de la unidad continental: los factores geográficos, históricos, sicológicos, habían concentrado su atención. De ahí en adelante, él propone la aplicación del mismo método a todos los pueblos del mundo, destacando objetivamente todo aquello que pueda acercarlos $\mathrm{y}$ todo aquello que, en aquel momento, los dividia; el estudio de las tensiones se revelaba no menos indispensable.

Esta trayectoria supone un objetivo, un deseo, un método.

1) Un objetivo: EI derecho internacional no debe más ser totalmente entregado a los azares de las negociaciones diplomáticas sino que debe ser objeto de una elaboración objetiva y, por expresar la palabra, cientifica. Ciertamente siempre habrá lugar para negociaciones y compromisos. Alvarez es demasiado realista para negarlo pero estima necesario, para aquellos que construyen el derecho internacional, el percibir mejor hacia dónde ellos van. Es menester que el jurista y el sociólogo Ies muestren las vías del verdadero realismo: no aquel que se confunde históricamente con el maquiavelismo, sino aquel que hace surgir las realidades, las necesidades sociales y los medios para hacerle frente.

Antiguamente el derecho internacional resultaba de cálculos más o menos de corto plazo, de intenciones ocultas en materias territoriales o dinásticas, particularmente en los si- 
glos XVII y XVIII, época en la cual reinaba la concepción patrimonial de la soberanía.

Luego en el siglo XIX se llegó a la conclusión de que todos estos cálculos habían terminado por repartir a los pueblos y a la soberanía de una manera sumamente arbitraria. Cuando las ideas de la Revolución Francesa se expandieron y, como consecuencia del principio democrático, engendraron el derecho de Ios pueblos a autodeterminarse, se constató que frecuentemente no existía ninguna coincidencia entre el fenómeno nacional y el fenómeno estatal. Minorías nacionales surgieron entonces en numerosos países. Fue el gran movimiento de las nacionalidades, movimientos de emancipación explosivos los cuales, en aquella época, eran imposible de comprender por aquellos en contra de quienes iban dirigidos.

Hoy día este movimiento alcanza a los pueblos de Asia y de Africa: es el principio de las nacionalidades que continúan extendiéndose como el fuego en los matorrales.

De esta manera se ha visto el nacimiento de diecinueve Estados nuevos en algunos años. El número total de Estados se ha duplicado desde comienzos de siglo. La llegada de estos nuevos Estados a la vida internacional conlleva profundos trastornos en los medios de cxpresión de ésta.

Dos movimientos contrarios recorren, en efecto, la sociedad internacional: uno conduce a la cooperación y a la unión y explica la multiplicación de las organizaciones internacionales; el otro conduce a la proliferación de Estados, encarnación de nacionalismos tanto más virulentos y apegados al dogma de Ia soberanía cuanto más reciente es su soberanía. Resulta así una extraordinaria movilidad de las situaciones políticojurídicas.

En medio de estos movimientos, los grandes, luego de haber construido sus zonas de influencia, se lanzan en una competencia implacable respecto de los paises que recién acceden a la independencia nacional o que están en vías de acceder a ella, lo que se realiza esencialmente por tres medios: la amenaza de conclusión de pactos militares, los regalos por 
la vía de la prosperidad, la promesa por la vía del mesianismo.

Todos estos acontecimientos, tensiones y reagrupamiento son los que debemos estudiar si se desea sentar las bases de normas internacionales suficientemente coherentes.

Ello involucra una confesión que muchas veces dudamos de hacer, pero que Alvarez estima indispensable y que él presenta como un desafío al juridicismo de estricta observación:

2) Problemas de interpretación politica. Se trata de la primacía de lo político sobre lo jurídico con su corolario: la imposibilidad de resolver las dificultades actuales del mundo recurriendo al derecho internacional clásico.

Si se toma la distinción de lo jurídico y lo político, se sabe que lo primero involucra situaciones fundadas sobre un derecho incontestado, cuya aplicabilidad no merece dudas a nadie; por el contrario, lo político supone que algunos rechacen de reconocer la validez del derecho existente y reclamen uno nuevo. Tal es la oposición tradicional de los conflictos jurídicos y políticos. Si ello se aplica al mundo actual se puede apreciar que los Estados no pueden recurrir al derecho internacional clásico, pues muchos de ellos se cuentan entre los que lo rechazan.

Entre los dos grandes cada uno tiene su propia concepción del derecho; su común adhesión a la Carta de las Naciones Unidas es impotente para disimular estas profundas divergencias.

Las Naciones Unidas no pueden establecer la coexistencia pacífica entre ellos; suponen, por el contrario, que ella ya existe para poder funcionar. No dándose estas condiciones resulta que el preámbulo de la Carta enuncia objetivos que los miembros han aceptado pero que aún no están de acuerdo sobre el sentido de las palabras.

Entre los Estados antiguos y nuevos las oposiciones están muy lejos de ser menos agudas. Los Estados jóvenes, surgidos de una lucha anticolonialista, invocan gustosamente el Derecho Internacional clásico en la medida en que algunas de sus 
reglas - las más antiguas-- vienen a respaldar su soberanía, pero lo rechazan cada vez que ven en él la proyección mundial de lo que fue el expansionismo de Europa. Oponen entonces a las reglas del Derecho Internacional principios que, para unos, surgen de concepciones seculares que les son propias - tal es el caso de las Reglas del Corán entre los pueblos árabes--, en tanto que para otros son forjadas bajo la presión de las necesidades presentes y dentro del designio de consolidar su independencia todavía frágil.

Se miden las desconfianzas recíprocas, las susceptibilidades, la capacidad de irritarse prontamente por el paternalismo de los pueblos ricos, oponiendo a las proposiciones de alianzas militares de los unos o de los otros un neutralismo dispensador de beneficios.

Una cooperación constructiva de los antiguos y de los nuevos permanece, en estas condiciones, todavía muy endeble e improbable, particularmente en lo que respecta a formas que suponen una cierta integración. Bien se pudo apreciar a propósito del asunto del Canal de Suez. Estados europeos y algunos Estados no europeos, particularmente los Estados Unidos, proponían un régimen de administración supranacional. En la Europa de los seis se ha recurrido a técnicas de este tipo; la CECA, el Euratom, la comunidad económica, atestiguan sus aplicaciones entre los viejos Estados decepcionados de las alegrías amargas de la soberanía. Aquellos para quienes la soberanía es un bien cnteramente nuevo continúan afirmándola y se oponen, y los pueblos afroasiáticos han comprendido la negativa de Egipto.

Esta extraordinaria movilidad de las situaciones políticojurídicas impone la necesidad de investigaciones profundas acerca de las causas de estos diversos fenómenos, su forma y su alcance respectivos.

El derecho clásico suponía un marco relativamente estable en cuyo interior podian producirse evoluciones algunas veces violentas; al menos el marco mismo no era afectado. De ahí la necesidad de métodos nuevos. 
3) Los nuevos métodos. Alvarez insiste en la necesidad de estudiar la vida internacional en sí misma.

El rechaza las doctrinas que se han esforzado en encontrar un fundamento al derecho internacional. Las unas y las otras le parecen no responder al estado actual de este derecho.

Se sabe que dos escuelas fundamentales se oponen, aquella del Voluntarismo y aquella del Objetivismo. Todas son para Alvarez ejercicios espirituales, tesis apriorísticas. Examinemos su posición en relación a las principales de estas escuelas.

a) Para el Voluntarismo sólo la voluntad del Estado puede obligarlo jurídicamente. Esta doctrina se subdivide en dos ramas: la teoría de la autolimitación y aquella del acto-unión.

- Para la primera, el Estado se limita por sí mismo cuando lo desea. Jellinek dice: "El Estado es superior a todos los principios jurídicos: El Derecho Internacional existe para los Estados y no los Estados para el Derecho Internacional". EI Estado crea de esta manera su propia ley en los asuntos internos y externos. A su respecto puede sostenerse que el Derecho Internacional que el Estado formula por sí mismo es un derecho interno de uso externo.

Tal doctrina, que explica bastante bien algunas prácticas internacionales del siglo XIX, está en la opinión de Alvarez obsoleta y condenada por la interdependencia social que frecuentemente, y a pesar de ello, transforma a los pueblos y a los Estados en tributarios los unos de los otros, a pesar de todo lo que continúa oponiéndolos.

- La segunda formulación de Voluntarismo es aquella de la Vereinbarung, como lo califican los autores alemanes, o acto-unión que identifica como fundamento del derecho internacional la voluntad común de los Estados que adhieren a una norma jurídica internacional. De ahí deriva que esta voluntad común es superior a la voluntad de cada uno de los Estados.

Esta teoria aparentemente contendría todos los elementos para satisfacer a Alejandro Alvarez, quien demostró que 
los Estados del Nuevo Mundo habian expresado una voluntad común de vivir en conjunto de acuerdo a ciertos principios.

Pero la teoría no va muy lejos; ella no explica por sí misma las razones de este acuerdo de los Estados. Respecto del hemisferio occidental, precisamente, Alvarez había investigado las bases de esta unión. Que la norma internacional supone un acuerdo, una adhesión de los Estados, no es negable pero esta aceptación corre el riesgo de ser precaria. Falta saber cuándo y cómo un acuerdo tal puede ser obtenido con cierta base de solidez; para ello es menester descubrir las bases sicológicas, económicas e históricas del comportamiento de los Estados.

La necesidad de investigaciones realistas preside la reacción de Alvarez respecto de las doctrinas clásicas; aquellas que descansan sobre el objetivismo no tendrían de parte de él una apreciación con criterio distinto.

b) Sabemos que para las doctrinas objetivistas, el fundamento del derecho reside en una noción exterior a los Estados y que los condiciona. Para algunos esta noción se encuentra en el derecho natural, para otros, particularmente para la Escuela de Viena y Hans Kelsen, en un principio, aquel de las jerarquías de las normas; otros todavía lo fundamentan en una solidaridad social.

Alvarez rechaza la doctrina del derecho natural. Algunas veces uno pudo equivocarse pues elaboró declaraciones de derechos y deberes de los Estados, y estas declaraciones históricamente se asimilan a esta doctrina; ellas proceden de la revelación de verdades trascendentes. Sin embargo, en el caso de Alvarez, las declaraciones, como lo veremos en otra parte, proclaman principios admitidos por los Estados, que encuentran su fundamento en este acuerdo estatal y, por otra parte, corresponden a la evolución de la colectividad internacional. es decir, no expresan reglas eternas fundamentadas en un derecho natural superior y permanente en el espacio y en el tiempo. 
Alvarez no podía plegarse a una doctrina cuyas incerti. dumbres frecuentemente han sido denunciadas, estando los propios partidarios del derecho natural en desacuerdo acerca de su contenido si bien están de acuerdo en torno a su valor permanente. El pretende, por el contrario, formular principios que cualquiera que sea su trascendencia expresen el estado social del mundo actual.

Al rechazar la Escuela del Derecho Natural, Alejandro Alvarez tampoco se pliega a las teorías de Hans Kelsen sobre el Normativismo. Siendo fundador de "la Escuela de la Vida", Alvarez no puede estar sino muy lejos de una doctrina que desea por el contrario definir las líneas del derecho puro.

Ustedes conocen lo que debe entenderse por la teoría normativista de la Escuela de Viena: El derecho se establecería de acuerdo a una pirámide de normas jurídicas jerarquizadas, coronadas en la cima por una norma originaria que desencadenaría una reacción en cadena de normas jurídicas para descender, por intermedio de la norma internacional, hacia la norma nacional, hacia otras normas en situación inferior.

Kelsen no realiza una búsqueda de los objetivos del derecho sino que, por el contrario, se remonta hacia la fuente primaria, hacia esta norma originaria que provoca la reacción en cadena de normas superpuestas. Llega de esta manera a una abstracción, encontrando - es menester reconocerlo- numerosas dificultades para identificar esta norma originaria, csta "ursprungnorm". Concluyendo en una abstracción, él se aleja de la vida y a este respecto no podría retener por mucho tiempo la atención de Alvarez.

En cambio este último parecería estar mucho más cercano de aquellas doctrinas que, tal como la del solidarismo de Politis o incluso de Scelle, ven en el derecho la traducción del hecho social.

c) Las escuelas solidaristas. Para la doctrina solidarista, la solidaridad social conlleva una coacción y cuando esta coac- 
ción es percibida conscientemente se transforma en normas jurídicas. La vida en sociedad $\rightarrow$ y el hombre es un animal social - crea de esta manera un conjunto de coacciones; los hombres terminan por tomar conciencia y lo que hasta este momento no cra sino una fuente material del derecho -es decir puricidad todavía inexpresada- será expresada formalmente por el poder, el cual le va a dar un alcance coactivo incorporándola en su cuerpo de reglas legislativas.

Ciertamente Alvarez también discrepa de la Escuela Solidarista, particularmente de la mayoría de sus conclusiones inspiradas por un riguroso monismo jurídico propio de esta escuela.

Rechaza igualmente la jerarquía de las normas juridicas que se encuentra en esta Escuela así como en la Escuela de Kelsen; rechaza la mayoría de las conclusiones a las cuales llegan los solidaristas.

Sin embargo está de acuerdo con ellos en el reconocimiento de que las necesidades sociales, una vez que los hombres han tomado conciencia, concluirán por crear el derecho. Es, entonces, desde el punto de vista del fundamento, que él se acerca a los solidaristas. El único punto de contacto con esta doctrina es aquél del fundamento; lo que es bastante decir.

Alvarez, así como Nicolás Politis, podía escribir: "El Derecho no es ni la emanación de un orden, ni la manifestación de una voluntad; simplemente es un producto social, un mero hecho transformado en derecho". Puede apreciarse asi que Alvarez fundamenta el Derecho Internacional en la conciencia jurídica de los pueblos.

Esta identidad de puntos de vista debe sin embargo ser matizada por medio de dos observaciones:

- La primera es una observación de vocabulario: Georges Scelle y Nicolás Politis hablan de solidaridad; sostienen que el Derecho es el resultado de la solidaridad creada por las necesidades sociales. Es la solidaridad que se encuentra en la base de toda regla de derecho. 
Alvarez no habla de solidaridad, o al menos no habla en el mismo sentido. El habla de interdependencia. La palabra solidaridad en el vocabulario de Alvarez se refiere a los sentimientos de fraternidad que unen a los pueblos de un mismo continente o a los pueblos de una misma raza, o a los pueblos de una misma religión, ligados por afinidades particularmente estrechas. La solidaridad es por tanto un fenómeno singularmente profundo, acerca del cual los pueblos tienen conciencia y en torno al cual desean alcanzar su plenitud.

$\mathrm{La}$ interdependencia es un fenómeno del mismo orden pero que no hace intervenir elementos subjetivos. La interdependencia es un fenómeno automático; ella se produce en forma independiente de que los pueblos hayan tomado conciencia de ella o no, en circunstancias que la solidaridad es una interdependencia en torno a la cual los pueblos han tomado conciencia, han aceptado y desean desarrollarla.

- Segunda observación: para Alvarez no basta decir que el Derecho encuentra su fuente en la conciencia jurídica de los pueblos. Las escuelas que acabo de indicar -aquella de George Scelle y Nicolás Politis - también lo dicen, pero ellas concluyen allí; el estudio de esta solidaridad en sí misma no es la tarea del jurista. En cambio para Alvarez es menester estudiar esta conciencia en sí misma para conocer y comprender el derecho y ayudar de esta manera a los gobiernos a definirlo. A este respecto es menester recordar que la obra de Alvarez, como diplomático en las Asambleas Panamericanas, ayudaba al Sistema Interamericano a salir de los pantanos adonde lo habían llevado el intervencionismo sistemático de los Estados Unidos hasta 1933 y las desviaciones del monroísmo. Mucho trabajó por depurar el sistema interamericano y tiene al menos la satisfacción de ver que esta tarea se ha cumplido y que, en la hora presente, cualesquiera que sean las vicisitudes por las cuales atraviesa el sistema interamericano y la solidaridad continental, conoció durante la presidencia de Franklin D. Roosevelt un impulso que era imprevisible antes de 1933. 
La sicologia de los pueblos como base del nuevo orden

De esta manera los estudios acerca de la sicología de los pueblos resultan determinantes, pues una vez afirmada la conciencia jurídica de los pueblos como fundamento del derecho no se puede considerar el problema resuelto, como lo han hecho todos los otros autores; todavía es menester estudiar esta conciencia. Esta tarea es considerada como ajena a los juristas por la mayoria de las escuelas, en cambio que para Alvarez surge al primer plano de las tareas que el jurista debe imponerse.

Han habido ya otras tentativas en el mismo sentido. El gran jurista suizo Max Huber ha demostrado que el derecho tiene una función social y que es menester ayudarlo en su cumplimiento. Particularmente en su célebre arbitraje del 4 de Abril de 1928 en el asunto de las Islas Palmas, asunto que dividía a los Estados Unidos y a Holanda, Max Huber escribió: "El Derecho Internacional tiene por objetivo asegurar la coexistencia de intereses diversos en las líneas de protección jurídica". Sus trabajos fueron seguidos por su sobrino Schindler, autor de un curso en la Academia de La Haya en 1933, titulado "Contribución al estudio de los factores sociológicos y sicológicos del Derecho Internacional". Demostró cómo estos factores sociológicos y sicológicos intervienen en la vida internacional.

Pero todas estas tentativas, que son dignas de homenaje, parecen como insuficientes para Alvarez.

En efecto, según él, no puede uno contentarse con decir que la sicología y la sociología tienen una importancia determinante. Ello sólo permite permanecer en lo abstracto. Y todas estas teorías tienen un defecto que las condena al fracaso: todas concluyen en una sociología sobre cuyo contenido el desacuerdo entre los autores es inevitable. Con frecuencia el problema se complica más todavia por las opciones metafísicas. 
Tales no serían actitudes suficientemente científicas. Para Alvarez es menester estudiar la vida internacional en si misma, considerarla tal como es y no como se desearía que fuese, para responder a la noción que pueda obtenerse de la sociología. Puede decirse que él introduce en el derecho de gentes todos los elementos propios de la vida, los elementos jurídicos, económicos, sicológicos.

Más todavía, sostiene luego de observar la vida a través de la historia que la organización del mundo debe realizarse organizando la vida. Así elaboró un proyecto de reconstrucción del Derecho Internacional que algunos lo han calificado de genial (3). Ciertamente este proyecto de reconstrucción del Derecho Internacional sedujo a los más variados juristas $y$, lo que es más sorprendente, sedujo también a los positivistas. El positivista es el hombre que reivindica la modestia; él no desea más que conocer la norma de derecho, interpretarla lo más fielmente posible y aplicarla; él no se propone reformarla. Es el partido de la sabiduría. Todo jurista debe tener una dosis de positivista.

Desde el comienzo de su vida cientifica Alvarez se presentó como un reformador, esto es, sin negar el deber de un jurista de estudiar el derecho positivo, quiso ir más allá y se ubicó en un punto de vista diferente.

De todos modos recibió incluso un estímulo de parte de los positivistas. Pienso particularmente en Jules Basdevant que le dijo: "Nada es más difícil que comprender nuestro tiempo; es mucho más fácil comprender el pasado que el presente y que por cierto vislumbrar el futuro; pero verdaderamente es un gran mérito del señor Alvarez trabajar en este sentido y aportarnos los resultados de sus trabajos" (4).

El propio positivista cuando desea aplicar el derecho, encontrándose en un período revolucionario, debe preguntarse:

(3) "Es el caso de Krupp y de Albert de Lapradelle, que consagraron un capíulo dedi. cado a Alvarez en su obra "Maitres et Doctrines du Droit de Gens".

(4) Citado por Matesso, "Le Druit Internationale Nouvcau", pág. 40. 
¿Dónde está el Derecho? ¿Está aquel que se encuentra en alguna colección de textos que figuran en su biblioteca todavía en vigor? El respeto del positivista por el derecho sólo es concebible en una época de relativa estabilidad. En una época revolucionaria ni siquiera el príncipe de los positivistas sabría hacia dónde dirigirse, puesto que por definición misma los códigos se encuentran más o menos obsoletos.

\section{Las ciencias auxiliares del derecho internacional}

Para llegar cntonces a esta búsqueda objetiva de las realidades de la vida internacional, Alvarez propone la creación de ciencias nuevas: Ciencias auxiliares del Derecho Internacional. Ustedes saben que la historia dispone de ciencias auxiliares, como la arqueología, la diplomacia, y otras. Y quienes emprenden estudios históricos deben también emprender la investigación a través de estas ciencias auxiliares. El propone la creación de ciencias auxiliares que deben permitir el comprender al conjunto de la vida internacional y medir la amplitud de las modificaciones que ella ha sufrido, sobre todo después de 1939, así como las repercusiones que estos trastornos han tenido sobre el derecho internacional.

Siempre dentro de su espíritu reformador no se abandona, entonces, al empirismo; presentó sus ideas - sobre todo después de 1941- particularmente en un libro escrito en espanol, publicado en Santiago en 1944, y en una conferencia que en la época causó sensación, en 1947, en la Asociación de Francia y América.

¿Cuáles son sus ideas a este respecto? Partiendo de la observación de que nos encontramos en un periodo de transición entre el orden antiguo y el nuevo orden, estima que se ha producido una renovación de las bases de la vida social de la cual debe resultar una renovación de las ciencias políticas, jurídicas y sociales que se fundamentaban en ellas. 
Para conocer el nuevo orden y emprender debidamente la renovación de las ciencias políticas y sociales, es necesario tener en cuenta estas modificaciones y la aparición de nuevos factores. Hasta este momento, según él, ninguna ciencia nos puede dar este conocimiento. La historia es insuficiente. La sociologia, acabamos de verlo, también lo es. Es necesario entonces crear nuevas ciencias y Alvarez nos propone tres. Estas tres ciencias son nuevas, pues, dice él, es un error creer que todas las ciencias sociales ya han sido establecidas. Estas nuevas ciencias son:

1) La ciencia de la evolución de la vida de los pueblos;

2) La ciencia de la sicologia de los pueblos en materia internacional;

3) La ciencia de las bases de la vida social.

EI realiza un esbozo de cada una de estas tres ciencias recientemente creadas y la obra que actualmente tiene en preparación se extiende sobre ellas.

La ciencia de la evolución de la vida de los pueblos

La ciencia de la evolución de la vida de los pueblos le ha mostrado la evolución de la vida internacional, y no solamente la evolución de la vida internacional, sino también su influencia sobre las bases esenciales deI Derecho de Gentes. No se trata de una ciencia que deba confundirse con la historia pues no es ésta una cronología; es la investigación de las leyes de un evolucionismo, de Ia misma manera que aquellos que han estudiado el evolucionismo sobre el plano teológico no han querido escribir la historia del hombre. Debe entonces Ilegar a una sistematización de las etapas de esta evolución, no solamente en Europa o en América, sino también en todo el mundo.

$Y$ desde ya puede observarse que, en cierta medida, las universidades - particularmente las universidades francesasacogen esta sugerencia. Ustedes saben que se ha creado en 
las Facultades de Derecho francesas un nuevo diploma de Estudios Superiores de Doctorado: Es el Diploma de Ciencias Políticas $y$, entre las materias que pueden ser enseñadas y escogidas por los estudiantes, hay una, agrupada bajo el nombre general de "Relaciones Internacionales", que no debe confundirse con el estudio del Derecho Internacional. Pueden tomarse estudios muy diversos al margen del campo jurídico pero que conciernen esencialmente a la evolución de la vida internacional.

\section{La ciencia de la sicología de los pueblos}

La segunda de sus ciencias, la ciencia de la sicologia de los pucblos, no debe extrañarnos en la pluma de Alvarez, puesto que el señor Vichinsky en la Asamblea General de las Na. ciones Unidas ha reconocido en él al Jefe de la Escuela Sicológica. Desde luego que resulta curioso observar que mientras uno lo consagra como el Jefe de la Escuela de la Vida, otros lo consagran como el Jefe de la Escuela Sicológica; se debe precisamente a que su pensamiento es muy rico, la manera de considerar los problemas es muy hábil y que, según cl punto de vista en el cual uno se ubique, se tiende a considerar un aspecto determinado de este amplio pensamiento.

La sicologia de los pueblos se encuentra en el centro mismo de sus preocupaciones.

Esta ciencia nos demuestra la importancia de los factores sicológicos y su influencia sobre las bases esenciales del derecho internacional. La vida internacional debe ser estudiada en función de lo que él llama "los imponderables". El los define como sentimientos sobre diversos aspectos nacionales, de sociabilidad, internacionales, reflejos sociales, estados de espíritu, doctrinas: Factores todos que no deben descuidarse pues son ellos precisamente los que guían a los pueblos en la realidad de sus relaciones recíprocas. En la hora actual es posible apreciar este fenómeno de mejor manera que anta- 
ño; en la época de la diplomacia secreta los pueblos no intervenían. Hoy día intervienen pero ello produce como consecuencia que los problemas diplomáticos sean mucho más difíciles de resolver que antes y particularmente se plantean ahora problemas de "prestigio". Ustedes conocen la expresión: se trata de conservar la imagen, para cuyo efecto los gobernantes algunas veces se inclinarán a adoptar determinadas actitudes, a perseverar en una cierta política más allá del momento al partir del cual hayan comprendido que más valia haber cambiado, porque la sicología de su pueblo no le permitirá retroceder. Esta sicología de los pueblos es un elemento extraordinariamente delicado de manejar: los gobernantes se sirven de ella para apoyar alguna reivindicación internacional, pero una vez que han recurrido a ella es muy difícil retroceder; y es siempre un momento muy grave en la vida de un hombre político aquel en el cual decide llamar a tal o cual rasgo de la sicología nacional.

Los problemas de imágenes en la hora presente envenenan las relaciones internacionales, precisamente porque no se desea verles. El Derecho Internacional clásico no tenía lugar para los problemas de imagen puesto que no existían; son problemas nuevos.

Es menester tomar en cuenta estos factores y estudiarlos con cuidado para ver en qué medida intervienen, en qué medida es necesario que intervengan o, por el contrario, es necesario limitar el recurso a estos factores en algunos casos.

\section{La ciencia del estudio de las bases de la vida social}

Por último, la tercera ciencia, la ciencia del estudio de las bases de la vida social, permitirá destacar los cambios sufridos por las bases de esta vida y la necesidad de una nueva concepción del Estado, la necesidad de una nueva concepción de las relaciones internacionales que ya no pueden ser concebidas como lo eran antes, en una época en que el derecho era estrictamente interestatal, intergubernamental. 
Por medio de esta tercera ciencia Alvarez nos invita a una investigación profunda de los elementos materiales y, particularmente, de las relaciones económicas.

Estas ciencias tendrán por objetivo el otorgar una visión de conjunto de la vida de las naciones; y deberán proporcionarnos una visión objetiva fundada sobre la observación imparcial de los hechos, una visión amplia que debe extenderse a las relaciones de los pueblos del mundo entero y no solamente a aquellos del Viejo Mundo, de los satélites, porque ellas hacen jugar todos los factores de la vida internacional.

En estas condiciones, ellas nos permitirán si acaso no deducir las leyes sociales que rigen la vida de los pueblos y que todavía ignoramos, al menos comprender los grandes rasgos. Es necesario estimular los trabajos, las monografías, sobre puntos especiales; es menester constituir en el curso de los años que vicnen bibliotecas enteras centradas sobre los problemas de base de la vida internacional, de la sicologia, de la evolución de los pueblos en sus relaciones mutuas -y sobre todo, gracias a este aporte de conocimientos precisos, proporcionar un nuevo criterio de apreciación de los acontecimientos internacionales.

Con el criterio actual, que es un criterio de estricta legalidad, ningún resultado práctico se conforma a las condiciones presentes de la vida de los pueblos. Sobre todo, y es aquí donde creo que esta doctrina es extremadamente original, todos estos elementos reunidos proporcionarán las bases de la solución del grave problema de la división del mundo en dos bloques: el bloque Este y el bloque Oeste.

\section{El nuevo orden y la politica de bloques}

En efecto, si se realizan estos estudios que Alvarez ya ha estructurado se apreciará que, en el fondo, la oposición entre el Este y el Oeste es mucho menos profunda de lo que se tiende a imaginar. Es una oposición en que hay que romper la mistificación. Y esta ruptura de las oposiciones entre el 
Este y el Oeste no es posible sino por medio de estudios objetivos, por tanto científicos. Si uno se inspira en su método, y se mantiene aquí sobre un plano necesariamente general, parece que ello supone dos tareas:

- La primera: Es menester descartar las reacciones sentimentales como la noción del enfrentamiento fatal; no es una actitud cienfífica la de creer en la fatalidad;

- Y en segundo lugar: Objetivizar las situaciones respectivas del Este y del Oeste, porque de todos modos es el acontecimiento que en la hora presente singulariza la división de la colectividad internacional en dos grandes bloques. Alvarez no podía sino chocar contra este acontecimiento, y es precisamente por la vía de la ciencia objetiva que él entiende que debe abordarlo.

En primer término es necesario, entonces, descartar la noción de fatalidad en la oposición entre estos dos bloques.

En efecto, estos dos bloques se oponen sobre la base de objetivos muy precisos. Esencialmente, si se realiza un estudio objetivo, se percibe que el uno preconiza la libre empresa en tanto que el otro preconiza la economía socialista. Pero es menester tener presente que con el tiempo vendrá una cierta decantación en los sistemas, y hay una que ya ha sobrevenido; hay una cierta colectivización. Incluso en los Estados Unidos los economistas han logrado demostrar múltiples manifestaciones. De la misma manera, antes hubo una oposición entre la Revolución Francesa y sus adversarios, que tenía un carácter místico y casi religioso; luego esta oposición progresivamente fue decantándose en el curso de la historia; las causas de la democracia se desprendieron de su aspecto metafísico, y de esta manera, con el tiempo, se desprendió de su agresividad antirreligiosa. El debate fue reducido a planteamientos institucionales, el debate entre la democracia y el antiguo régimen se redujo a un problema de técnica constitucional.

En el conflicto actual es inevitable que una decantación similar intervendrá, siempre que se realice el esfuerzo de adelantar la historia. 
Observemos desde luego que la opción entre las dos formas económicas responde a fenómenos bastante naturales, ajenos a toda consideración sentimental o religiosa. En Gran Bretaña como en Estados Unidos, por ejemplo, nos encontramos en presencia de países que se prestaban para el desarrollo del capitalismo; el individualismo económico debía tener éxito inevitablemente; y luego la explotación de las riquezas debia exigir unidades económicas cada vez más grandes, de suerte que, en estos países, se partió de la empresa liberal individualista para llegar final y progresivamente a la gran empresa.

Por el contrario, si consideramos un mundo como Asia, el carácter de la naturaleza de este continente, sus inmensidades, se constata que los capitales se comprobaron impotentes; fue necesario antes que nada abrir las cuencas de carbón y de hierro distantes varios miles de kilómetros, regar los desiertos, desviar hacia el Mar Caspio los grandes ríos del Océano Glaciar Artico, fue necesario modificar la geografia; se debió comenzar por ahí.

Dicho de otro modo, Rusia Soviética no tuvo el tiempo de construir un capitalismo privado y se encontró con que debió pasar bruscamente del artesanado al complejo industrial, en circunstancias que Gran Bretaña pasó del artesanado a la libre empresa capitalista del siglo XIX antes de llegar al complejo industrial. En la revolución soviética se comenzó por la industria pesada y por el complejo industrial del Estado.

Finalmente son necesidades de orden geográfico e histórico las que, en gran medida, explican todo esto.

Si tratamos de seguir la ruta que Alvarez nos muestra, si tratamos de realizar una reflexión objetiva sobre las razones fundamentales de esta oposición de técnicas cconómicas entre el Este y el Oeste, comprenderemos que hay numerosas razones que nada tienen que ver con las opciones metafísicas.

$Y$ si en la hora presente el colectivismo ejerce un cierto atractivo sobre los pueblos de los países menos desarrollados -n Asia, en India y en otras partes-, no es tanto porque 
estos pueblos hayan sido siempre seducidos por el marxismo, en tanto que el marxismo puede ser considerado como una religión, en circunstancias que estos pueblos de Asia tienen sus propias religiones singularmente antiguas y respetables $\mathrm{y}$ que no les falta fuerza frente a esta herejía cristiana y materialista que es el marxismo.

Lo que puede seducir a un pueblo subdesarrollado es sobre todo la tćcnica colectivista, pero en un plano estrictamente técnico, es decir, que por medio de estas técnicas se podrá tener un éxito más rápido que el que permitiria recurriendo al capital privado. Sea como fuere es menester saber precisamente si las investigaciones de sicología permitirían apreciar cn qué medida los pueblos subdesarrollados se hacen cste razonamiento. $\dot{c}$ Es éste verdaderamente un litigio de dos concepciones del mundo, o más bien una opción entre dos medios para llegar al desarrollo económico y a la productividad?

De esta manera la opción entre el capitalismo y el colectivismo sc explicaría en parte por razones técnicas y geográficas.

Ciertamente no se puede negar que una concepción del hombre también está involucrada en el debate; pero las nociones que se refieren a las concepciones del hombre tienen un lugar muy preciso en este mismo debate. Cuando un mundo es dirigido de esta manera, no se trata de decir que se podrán superar las dificultades presentes optando integralmente en un sentido o en el otro. Puede considerarse por ejemplo que el fenómeno de clases es un problema que se plantea en todas partes. Incluso si algunos Estados pretenden que desde el interior de sus fronteras han resuelto el problema de las clases sociales, ello no impide que las clases también se encuentren en el exterior y que el problema se plantee en la escala del planeta. El problema internacional es un problema social planteado internacionalmente. En el mundo existen actualmente veinte personas de cada veinticinco que no satisfacen sus necesidades alimenticias. Un problema fundamenta] es aquel del hambre. 
El rol de la ciencia de la sociedad internacional es precisamente el de destruir las pantallas ideológicas proyectadas cn lo absoluto y demostrar las realidades de esta vida internacional.

Nos encontramos así en presencia de dos Estados: los Estados Unidos y la Unión Soviética, que se apegan cada uno a filosofías que hacen intervenir el materialismo y el espiritualismo. Pero antes, es menester tratar de comenzar a destruir la mistificación del problema.

\section{Proyecciones del nuevo orden}

Si se logra estudiar de esta manera, de una forma objetiva, las bases de la vida de los pueblos, se Ilevará a los hombres a reflexionar y a dominar sus impulsos pasionales que preparan Ias guerras de cruzadas, las guerras sagradas. Se les hará tomar conciencia - y sobre todo se les hará tomar conciencia a sus gobernantes- de todo aquello que une en medio de las diversidades, se analizarán los hechos que implican estas necesidades, y se les permitirá comprender mejor que son componentes de una misma humanidad. Cuando las contradicciones pierden sa carácter absoluto y metafísico, ellas pierden también su aspecto totalitario. Un análisis objetivo da argumento para la coexistencia pacífica.

Un análisis objetivo de la cvolución de la vida de los pueblos es comprender que hay mucha distancia entre las raíces y las copas, así como entre las soluciones desesperadas, tal como en las guerras, y los resultados a los cuales se llega.

Cicrtamente se puede estimar, por ejemplo, que los pueblos de Asia desean la reforma agraria; la reforma agraria es en Asia una necesidad económica y social. Pero es menester saber qué ganarán los campesinos de esta generación en Corea o en Vietnam si deben pagar como precio de esta reforma agraria no solamente sus tierras y sus restos calcinados, sino también la muerte. 
En cuanto a Francia e Inglaterra, ustedes pueden medir la sorpresa que les produce el comprobar, después de la Segunda Guerra Mundial, que se han visto despojados de una parte de su independencia y de su potencia, en circunstancias que eran partes en una guerra creyendo defender esta independencia y esta potencia y que, a la larga, se vieron despojados de la una y de la otra en beneficio de otros Estados, que permanecieron intactos.

La revolución por medio de la guerra no es más que multiplicar por miles los males y la miseria que se proponía subsanar.

Los hombres frecuentemente cometen un número de actos de locura en su existencia porque no saben hacia qué dirección han decidido dirigirse. Veamos el ejemplo clásico, la pregunta ritual: ¿Era Napoleón lo que deseaban los redactores de los cuadernos de 1789 cuando exigieron al Rey introducir modificaciones en el antiguo régimen? Se empezó con los Estados Generales y se terminó con el Imperio.

Es menester entonces investigar las bases de la justicia social, porque los fenómenos de interdependencia social entre todos los hombres obligan a esta reflexión y a esta investigación. Quizás entonces llegaremos al momento en que en el Este ya no habrá más Democracia Política y en el Oeste ya no habrá más Democracia Social. De todos modos, cualquiera que sea el resultado al cual se llegue, más vale tratar de encontrar una objetividad entre dos sujetos irritados, desesperados como aquellos que se confrontan en la hora actual, que confrontarse con armas ilusorias de un derecho internacional clásico y obsoleto, establecido en el período de los Estados principescos del siglo XVIII y que no podría pretender hoy día, sin caer en el ridículo, mantener la paz entre los hombres.

Ustedes pueden apreciar cómo partiendo desde este punto de vista de Alvarez se puede esperar una reducción de la antinomia entre el Este y el Oeste. Hemos indicado aquí sólo algunas líneas de las direcciones concebibles. Según él, traba- 
jos precisos conducidos dentro del marco de las tres ciencias, debían precisar y desarrollar los medios de conseguir una conciliación.

Concluimos así al examen al cual la doctrina de Alvarez invita, $\mathrm{cl}$ examen a las modificaciones de la colectividad internacional. Modificaciones de esta colectividad internacional que se aprecian tanto en sus dimensiones como en sus medios de acción, pasando por los trastornos que ella ha sufrido en su naturaleza y cn su espíritu.

De ahora en adelante, a la luz de estas observaciones muy generales y que no se reficren sino al estado actual de la colectividad internacional con el objetivo de hacerles presentix la influencia de estos trastornos sobre el estado del derecho internacional, debo, situándome en un plano mucho más técnico y jurídico, estudiar las modificaciones del derecho internacional mismo. Son estas modificaciones las que hay que scguir muy de cerca para apreciar en qué medida el derecho internacional clásico se encuentra en la hora presente, como lo sostiene Alvarcz, "caído en la obsolescencia", es decir, punto menos que inaplicable para resolver los problemas fundamentales que se plantean en el mundo.

Luego será necesario también medir la amplitud de los campos en cuyo interior el derecho antiguo todavía produce sus efectos, pues Alvarez desafía todo a priori. Desde el momento que este autor nos dice que nos encontramos en un periodo de transición, resulta que todavía la antigua juridicidad subsiste en potencia en el mundo actual. Hay un largo arrastre del derecho antiguo.

De la misma manera deberá medirse la aparición del nuevo derecho y los fenómenos de penetración o interferencia de ambos. Dicho de otro modo, nos encontramos nosotros mismos en una situación dialéctica entre el derecho antiguo y el nuevo derecho. Si rechazamos uno es en beneficio del otro. Y si consideramos el derecho antiguo veremos que él mismo está en tránsito hacia el derecho nuevo. En algunos campos - como la cuestión de los Tratados o la cuestión de la Respon- 
sabilidad Internacional de los Estados- veremos coexistir ciertas reglas del derecho antiguo $\mathrm{y}$, al contrario, surgir aquí alguias reglas nuevas en que solamente los trastornos fundamentales, acerca de los cuales llamé vuestra atención, pueden proporcionarnos una explicación.

Son precisamente estas interferencias entre el derecho antiguo y el nuevo derecho las que deberemos descubrir en estas clases. Por esta razón los invito a continuar las investigaciones en los capítulos siguientes:

-El primero será consagrado al estudio de las modificaciones del derecho internacional;

-y el segundo al examen de las interferencias entre el derecho antiguo y el derecho nuevo.

Estos dos capítulos constituirán la scgunda parte de este curso. 
Segunda Parte

ESTUDIO DE LOS TRASTORNOS CONCURRENTES QUE SE HAN PRODUCIDO EN EL DERECHO INTERNACIONAL

Para estudiar las modificaciones fundamentales del Derecho Internacional en la actualidad, seguiremos exactamente el mismo plan que seguimos respecto de las modificaciones de la colectividad internacional.

Retomando, en un paralelismo tan exacto como sea posible, la división que nos guió en la primera parte, veremos que el Derecho Internacional ha sido afectado en sus dimensiones y en sus centros de gravedad en primer lugar; en su finalidad, en segundo lugar y en sus medios de expresión, en tercer lugar. 

Capitulo I

LAS MODIFICACIONES DEL DERECHO INTERNACIONAL

Sección 1

\section{MODIFICACIONES EN SUS DIMENSIONES Y EN SUS \\ CENTROS DE GRAVEDAD}

Los trastornos que afectan tanto las dimensiones como los centros de gravedad del Derecho Internacional contemporáneo provienen principalmente de dos acontecimientos: por una parte los Estados ya no son los únicos sujetos del Derecho Internacional y, por otra parte, al lado de un derecho internacional considerado universal existe un gran número de derechos regionales. Ya no nos encontramos en la época de comienzos de siglo en que Alvarez combatia para tratar de que se admitiese la idea de un derecho internacional americano; en la actualidad hay diversos otros derechos regionales y examinaremos su existencia así como sus relaciones con el derecho universal.

\section{Los Estados no son los tínicos sujetos de Derecho}

Ciertamente lo anterior ha sido sostenido y enseñado por la mayoría de los autores de Derecho Internacional; pero pará Alvarez no es suficiente destacar la existencia al lado de los Estados de otras personas del Derecho de Gentes, sino que, además, es necesario estudiar las consecuencias que produ- 
cirá este advenimiento de nuevos sujetos sobre los problemas y los campos del nuevo Derecho Internacional.

¿Cuáles son estos sujetos que vienen a agregarse al Estado? Esencialmentc son dos: el individuo y la organización internacional.

\section{A. El individuo}

Ustedes conocen que la vida internacional tradicional fue alimentada casi exclusivamente por la acción de los Estados que se confrontaban en una competencia pacífica o en una competencia bélica de variable temperatura. La colcctividad humana que puebla el planeta se encontró repartida, a partir del siglo XVI especialmente, entre Estados en cuyo interior trataban de desarrollar sus facultades de acción en todos los planos y particularmente de lograr la libertad política.

Es necesario destacar que este largo esfuerzo del hombre por acceder a una mayor libertad, a un mayor bienestar social, fue sostenido en el interior del Estado. El diálogo entre el hombre y el Estado se ha desarrollado hasta ahora en el interior de sus fronteras, entre los ciudadanos de un mismo país y sus respectivos gobiernos. Es dentro de este marco estatal que cada colectividad ha luchado para obtener el máximo de justicia y de libertad. Puede entonces sostenerse que la conquista de la libertad política y del bienestar social no fue planteada sobre el plano global, universalista, planetario o mundial, sino que hemos asistido por el contrario a tantas tentativas paralclas conducidas en cpocas sensiblemente diferentes en el interior de los diversos Estados.

Es por ello, entonces, que puede sostenerse que la democracia ha sido establecida históricamente en la medida del Estado.

Habiendo acomodado así su existencia con la mayor seguridad y comodidad, el hombre confió al Estado su conservación e igualmente su participación en la vida internacional. Esta no podía ser entonces sino una participación indirecta 
por intermedio del Estado; es al Estado que el hombre entregó la tarea de negociar con otras naciones las relaciones de prestigio o beneficio.

Las normas que regulan estas relaciones en el Derecho Internacional Antiguo, en el Derecho Internacional Clásico, son entonces reglas puramente interestatales, incluso intergubernamentales; el Derecho Internacional mismo es un derecho que se desarrolló al nivel de los gobernantes y no de los gobernados. Siendo el Derecho Internacional Clásico un derecho intergubernamental, los gobernados no participaron.

Resulta como consecuencia que, en el Derecho Internacional Clásico, el Estado era el único agente juridico, el único actor que intervenía en la escena internacional, al mismo tiempo que era el único destinatario de las reglas de derecho internacional formuladas por los Estados para los Estados, y los individuos sólo se beneficiaban o lo sufrían en un segundo lugar por medio de una relación que en sí misma era una relación de derecho interno. El Estado solamente emergia en la vida internacional, y el derecho internacional no alcanzaba al hombre sino de una manera mediata.

Duranie mucho tiempo esta situación no pareció extraña. Y tampoco lo parccería hoy día si acaso la sociedad internacional no hubicse cvolucionado profundamente, como lo acabamos de ver en las lecciones precedentes.

La confusión de la vida internacional actual no es otra que aquella que proviene de un divorcio existente, de una parte, entre esta interdcpendencia sobre la cual Alvarez insistió tantas veces, que reúne a los hombres en una misma aventura y que tiende a establecer de esta manera su accesión a la vida internacional, puesto que existe un gran número de problemas que ya no pueden ser resucltos en el mero marco estatal; $y$, por otra parte, la estruciura cerrada de una sociedad interestatal que frena csta promoción del hombre y que continúa descando reservar a los solos Estados la solución de los problemas que su división, desde luego, no permite ya resolver. 
Observen bien que no tratamos de sostener que hay que suprimir el Estado. Algunos autores, guiados por un celo iconoclasta, han deseado quebrar lo que han llamado "la opaca pantalla estatal" que separa al individuo de la vida internacional y que le impide al hombre acceder como tal a esta vida internacional, y de proseguir, entonces, en el plano general planetario, esta obra de emancipación y de promoción que emprendió hace tanto tiempo y que hasta ahora no ha podido desarrollar sino al interior de sus fronteras originarias.

Frente a estas proposiciones destinadas a suprimir el Estado, fenómeno relativamente reciente, hay que observar que, cuando un sistema social se ha cristalizado, nos inclinamos a perder de vista Ias circunstancias históricas que han determinado su formación. En la Edad Media, por ejemplo, puede recordarse que Europa era considerada como una gran república en que el jusgentium constituía el derecho común; hubo lo que se llamó la "Civitas Christiana" que era una ciudad organizada a cuya cabeza se encontraba un poder temporal cn las manos del Emperador y un poder espiritual, el mismo en sus origenes como poder temporal, el poder del Papa (5).

Los Estados en cambio surgieron cuando la Edad Media terminó, tanto por razones materiales, que derivan particularmente de las consecuencias de los descubrimientos, como por razones espirituales, sobre todo derivadas de la Reforma que vino a privar al Papado de su poder espiritual, así como las nociones de la soberania del Estado lograron privar al Emperador del Sacro Imperio Germano-Romano de su poder. Se presenció entonces esta división y la creación de los grandes

(5) El poder del Papa era considerable puesto que podía llegar incluso a la aplicación de sanciones temporales respecto de quienes detentaban la autoridad política, El Papa podía excomulgar al Principe oue pareciera no observar en sus relaciones internacionales la Ley Divina; y esta excomunión tenía una sanción politicamente de consecuencias muy graves puesto que producia por efecto liberar a los súbditos di: la obediencia que debian al Príncipe. Puede sostenerse que habia en el tiempo de la Civilas Christiana un régimen supranacional. 
Estados modernos. La sociedad interestatal es por tanto relativamente reciente; no siempre ha existido; quizás podamos concebir una sociedad en que los Estados ya no tendrán un lugar tan importante como aquel que detentan en la actualidad; pero estas no son evocaciones que seduzcan a Alejandro Alvarez.

\section{El realismo de Alvarez y el rol del individuo}

$\mathrm{Su}$ doctrina es fundamentalmente realista. No demuestra él una atracción particular respecto del mantenimiento del f́cnómeno estatal en la vida internacional contemporánea. Pero considera que, por lamentables que sean los excesos a los cuales ha llegado el estatismo o a los cuales amenazan con llegar todavia, cl Estado es un fenómeno que en la hora presente está todavía muy fuertemente implantado en la vida del mundo y que sería utópico tratar de que termine.

En efecto, tratándose de un momento en que como nunca se ha visto una multiplicación de los Estados, como lo demuestra el hecho que en los últimos años han nacido 19 Estados nuevos, no es la ocasión más propicia para solicitar la supresión del fenómeno estatal.

No parece, pues, que esta idea tenga alguna posibilidad de éxito en el futuro cercano.

Pero así como el Estado nunca ha tenido una potencia tan grande como la que tiene hoy día, pues utiliza todas las técnicas del poder singularmente más desarrolladas que aquellas que estaban a su disposición hasta hace pocos años, jamás tampoco ha debido enfrentar responsabilidades tan grandes, no obstante su potencia, no obstante sus técnicas.

El monopolio de la vida internacional por los Estados produce por efecto de que todos los problemas tiendan a politizarse y que su solución sea particularmente más difícil (6).

(6) No creenos que los Estados puedan acceder fúcilmente a la concepción del intercis general, y a este respecto somos menos optimistas que Alvarez. 
Las grandes necesidades de la colectividad humana son hoy dia de orden económico, social, cultural, y exigen de los hombres una colaboración en el seno de vastos conjuntos, en el seno de grandes instituciones, en las cuales puedan encontrarse representados como tales, en tanto que hombres, surgiendo en su situación de hombres, expresando ciertas necesidades y presentando ciertas reivindicaciones.

La composición de la colectividad internacional en Estados yuxtapuestos ha determinado que hasta ahora sea muy difícil la solución de los grandes problemas que se le plantea a la socicdad internacional, el problema del hambre, el problema de la lucha, los males sociales y especialmente las enfermedades. Existen organizaciones internacionales que se preocupan de estos problemas pero por ahora no son más que asociaciones interestatales que carecen de un verdadero poder de decisión; son instituciones de coordinación, pero les falta todavía una eficacia, lo que se debe, en gran medida, a la estructura de la sociedad interestatal.

De esta manera, como se ha dicho, la sociedad internacional es la menos humanista de las sociedades.

Pero la existencia de organizaciones internacionales que acabo de indicar nos demuestra precisamente que la consideración de lo humano se revela cada día como más presente y que, en estas condiciones, cl derecho puede ser sensible, y puede serlo de dos maneras:

-Desde luego en cuanto el Derecho puede organizar la vida internacional teniendo como objetivo principal el bienestar del hombre y no solamente el bienestar del Estado, que es el de una entidad jurídica política, bienestar este último que no se confunde necesariamente con aquel de los individuos que pueblan ese Estado o que pueblan los demás Estados. La gloria del Estado, la potencia del Estado, pueden encontrar grandes satisfacciones en aspectos en que también está en juego la suerte del hombre sin que los triunfos del Estado puedan ser siempre materia de felicitaciones. 
El Derecho, desde este punto de vista, puede entonces organizar la vida internacional con el objetivo principal del bienestar del hombre. La humanización del Derecho de Gentes ha comenzado $\mathrm{y}$ el individuo tiende a transformarse en uno de sus principales destinatarios.

- Por otra parte, desde un segundo punto de vista, puede concebirse igualmente que el Derecho Internacional utilice al hombre como agente jurídico, como factor de formación y claboración de las normas internacionales. En estas condiciones el hombre no es solamente el destinatario de la regla de derecho sino que también aparece como uno de los creadores de esta norma, en circunstancias de que hasta ahora ella no cra creada sino por los Estados, es decir por los gobernantes. Lo anterior significa que cn cierta medida los gobernados de los Estados acceden también a la vida internacional y que, también en cierta medida, adoptan la calidad de gobernantes.

Estudicmos, entonces, cómo el Derecho Internacional ha logrado hasta ahora satisfacer las dos maneras de abordar el problema del acceso del hombre a la calidad de sujeto del Derecho de Gentes, y tratemos de situarnos en la posición de Alvarez en relación a estos dos aspectos del problema.

1) El hombre se ha transformado en uno de los destinatarios de las normas de derecho internacional.

Desde hace tiempo los Estados vienen elaborando convenciones destinadas a satisfacer las necesidades colectivas de los hombres. Lo han hecho de una manera que no puede considerarse como plenamente satisfactoria puesto que la acción del Estado siempre está marcada por pensamientos políticos subyacentes, al no tener la libertad de espiritu necesaria para proseguir exclusivamente el bienestar de la humanidad; el Estado tiene desde luego debcres: aquel de satisfacer el interés particular de la colectividad de la cual está a cargo. 
No obstante este particularismo de las finalidades estatales, éstos se han esforzado desde hace tiempo en adoptar reglas que tengan por destinatario definitivo al individuo. Es así como, por ejemplo, en el Congreso de Viena en $1815 \mathrm{sc}$ adopta la regla de la abolición de la esclavitud; es de todos modos una regla considerable; desgraciadamente no fue aplicada en seguida pero ella surge como una de las primeras a considerar el bienestar del hombre como objetivo principal.

Dentro de esta perspectiva el Estado ha tratado de asistir al individuo en tres planos:

-En su comercio con el extranjero primeramente;

-en seguida, tratando de satisfacer las necesidades económicas y sociales del conjunto de la colectividad humana;

$-y$, en fin, para proteger al individuo en contra de los abusos del poder de la parte de los gobiernos; ello evidentemente representa el último punto de esta evolución.

a) El amparo diplomático. En lo que respecta a las relaciones jurídicas privadas que un ciudadano mantiene con un extranjero, el Estado siempre ha tenido el deber de asistir a sus nacionales en caso de necesidad. Una antigua institución - la protección diplomática de los nacionales en el extran. jero- permite a los Estados exigir a otros el respeto de sus personas y de sus bienes. Esta institución de la protección diplomática se explica, precisamente, por la exclusividad reconocida a los Estados en cuanto a la posibilidad de actuar internacionalmente. $Y$ es precisamente aquí que la separación del hombre de la vida internacional puede apreciarse muy claramente. Al no gozar de competencia internacional no puede actuar ante tribunales internacionales, quedando entonces sometido a merced de su Estado de origen, el cual a veces se negará a ejercer la protección diplomática en su favor por considerar que ello puede ser riesgoso en el plano político, siéndole de mayor interés permanecer en buenas relaciones con aquellos Estados a los cuales se podría dirigir. 
Hoy día, sin embargo, la institución de la protección diplomática, que tradicionalmente fue marcada por su carácter de privilegio perteneciente al Estado, evoluciona en el sentido de la protección de los derechos del hombre. Se la considera menos como una institución al servicio de la majestad del Estado -majestad ultrajada por el daño que uno de sus nacionales ha sufrido en el extranjero- y más como una institución al servicio del individuo. Las normas de la protección diplomática son hoy día más liberales que antaño.

Ciertamente que si se desea evitar el abuso de la protección diplomática en un sentido o en otro -en el sentido del imperialismo o en el sentido de la pusilanimidad que priva al individuo de una protección efectiva-, lo mejor es obligar a todos los Estados a respetar los derechos de los extranjeros en tanto que hombres. $Y$ a este respecto Alejandro Alvarez también se anticipó. En 1931 publicaba una declaración de los grandes principios del Derecho Internacional Moderno. Ella fue aprobada por la Academia Diplomática Internacional, por la Unión Jurídica Internacional y por la International Law Association. Representó entonces un texto de gran importancia desde el momento que recibió la aprobación de organizaciones compuestas por jurisconsultos de la mayoría de los países (7).

El título sexto de esta Declaración se llamó "Derechos Internacionales del Individuo" y el título séptimo, "Derechos y deberes de los extranjeros".

En el primero, Alvarez cnuncia cierto número de normas que deben obligar al Estado a asegurar a todo individuo en su territorio - ya se trate de nacionales o de extranjeros- la plena y entera protección del derecho a la vida, a la libertad, a la propiedad, sin distinción de nacionalidad, de sexo, de raza, de lengua o de religión.

(7) La primera edición de esta declaración fue traducida en varios idiomas, entre ellos el turco. Una segunda edición apareció en 1938 en las Ediciones Internacionales. 
Por otra parte, el artículo 30 de esta Declaración dispone que "los extranjeros tienen el derecho al mismo tratamiento que los nacionales en lo que respecta a los derechos privados y a las garantías del Derecho Penal". Estas son normas inspiradas directamente del Derecho Latinoamericano, pues en las relaciones entre las repúblicas de América Latina existe el principio de la asimilación de los nacionales y de los extranjeros en lo que respecta a los derechos privados y a las garantías del derecho penal. La adquisición de estos derechos privados cstá prevista por las convenciones de derecho internacional privado que ligan a todos los Estados del Nuevo Mundo, particularmente a las repúblicas latinas.

Es menester todavía citar otro artículo -el artículo 34-, que prevé que los extranjeros que hayan sufrido, de parte de las autoridades o de los particulares del país en que se encuentran, un daño que pueda comprometer la responsabilidad de éste, deben recurrir a las autoridades de este país. El Estado al cual pertenezcan no podrá otorgarles su protección diplomática sino en caso de denegación de justicia. Esta disposición tiene por objeto impedir que la protección diplomática se desvie hacia intervenciones imperialistas, que fue el gran fenómeno del siglo XIX en que los Estados curopeos y los Estados Unidos se ingeniaron para desencadenar intervenciones sistemáticas en favor de sus nacionales establecidos en el extranjero, aun en casos en que esta protección no era justificada, con el solo designio de ganar ventajas políticas o económicas en los países en contra de los cuales ellas se ejercian. Es esta amenaza la que se desea descartar por medio de esta disposición, previéndose una vez más la antigua norma del agotamiento de los recursos internos antes de que sea procedente o pueda ser utilizada la protección diplomática, pero agregando una reserva en el sentido de que la protección no podrá ser invocada sino en el caso de denegación de justicia, lo que evidentemente constituye una restricción a la práctica consuetudinaria de esta institución. 
Recién les mencionaba que por medio de esta declaración Alejandro Alvarez se anticipó a su tiempo. No hay que olvidar, en efecto, que después surgieron otras declaraciones, no solamente presentadas en sociedades de jurisconsultos, sino que también elaboradas en asambleas políticas internacionales y que han sido aceptadas por los Estados. Se trata particularmente de la Declaración Universal de los Derechos del Hombre de las Naciones Unidas, y de la Convención Europea de los Derechos del Hombre, del 4 de noviembre de 1950, que entró en vigor el 3 de septiembre de 1953, la cual consigna un cierto número de normas inspiradas directamente de la declaración del jurista chileno.

b) La protección económico-social. Por otra parte, los Estados han tomado conciencia de la extraordinaria red de relaciones comerciales diseñadas por sus nacionales, y de las necesidades económicas y culturales suscitadas por el entrelazamiento de los contratos e ideas.

Sobre todo son los problemas sociales los que se plantean ahora en la dimensión del mundo. Ya la Sociedad de las $\mathrm{Na}$ ciones, tan decepcionante en otros planos, había sabido promover una obra humanitaria considerable; la Organización de las Naciones Unidas ha venido a aportar un concurso nuevo y superior. La Carta de las Naciones Unidas es alimentada por un humanismo que encuentra su fuente en la tradición cristiana así como en los filósofos racionalistas del siglo XVIII. También resulta abismante la proliferación de organismos internacionales destinados a satisfacer las necesidades colectivas de la comunidad de hombres.

En diversas ocasiones Alvarez, en sus opiniones disidentes, insistió en la necesidad de referirse con mayor frecuencia que lo que se hace en la jurisprudencia internacional al preámbulo de la Carta y al capítulo I de este documento, que determinan los objetivos de la Organización. En efecto, debido a su humanismo, deben esclarecer al juez internacional acerca de la interpretación que deberá darle a las disposi- 
ciones de la Carta, de manera que el juez no interprete la Carta en un legalismo estrecho y particularmente en una perspectiva estrictamente interestatal, como era el caso en el derecho antiguo, sino que, por el contrario, guiarlo en su labor interpretativa a la Iuz de las finalidades humanistas que el preámbulo y el Capítulo I le imponen y que manifiestan claramente que la Organización de las Naciones Unidas no es solamente una institución diseñada en favor de los Estados, sino que, como su nombre lo indica, en favor de las Naciones, es decir de las colectividades humanas.

Si bien la jurisprudencia internacional es todavía un tanto timorata en el plano de las instituciones, la mayoría de los problemas han sido previstos: protección de los trabajadores, protección de la infancia, asistencia de los refugiados, organización de la aviación civil, telecomunicaciones, comercio y empleo, alimentación y agricultura, moneda, Bancos para la reconstrucción, valorización de territorios subdesarrollados, y podría continuar con una enumeración sumamente larga pero que sería fastidiosa.

De esta manera resulta evidente que si un diplomático de la época antigua, Talleyrand por ejemplo, regresara entre nosotros, todo le parecería tan extraño y desconcertante como la posibilidad de escuchar por audífono varias lenguas simultáneamente en el curso de la intervención de un delegado en una asamblea internacional.

c) La Declaración Universal de los Derechos Humanos. En fin, franqueando una tercera etapa —esta vez decisiva--, las Naciones Unidas han planteado la famosa Declaración Universal de los Derechos del Hombre, que por la primera vez en el plano político consagra la finalidad humana del Derecho de Gentes, formulando así la intención de tomar al individuo como la medida de la institución internacional.

Esta declaración no va sin embargo demasiado lejos puesto que hasta ahora no ha podido ser sancionada por la institución de un verdadero tribunal; en cambio, en el orden 
europeo, la Convención Europea de los Derechos del Hombre organizó todo un procedimiento. Prevé una Comisión Europea de los Derechos del Hombre que ya funciona en Estrasburgo y prevé también una Corte Europea de los Derechos del Hombre, la cual todavia no ha comenzado a funcionar porque el número de ratificaciones necesarias para su entrada en vigor no se ha reunido en el momento en que les hablo; pero hay ya un movimiento cuya primera fase está en funcionamiento $(8)$.

Frente a la creación de un procedimiento tal es necesario considerar la amplitud del paso que se ha dado. No se trata ya simplemente de tomar al hombre como destinatario de la norma internacional, sino que conduce a una transformación mucho más fundamental del derecho: hace del hombre no solamente un destinatario sino un agente jurídico, un actor en la vida internacional.

\section{2) El Derecho Internacional surge como obra del hombre}

El derecho de gentes ya no es más establecido para él, sino por él. Retomemos los tres planos que acabamos de considerar.

a) Las relaciones privadas. En primer término, en lo que respecta a las relaciones privadas, los progresos no han sido demasiado considerables y, para resolver los litigios que confronten a los extranjeros con los nacionales, los individuos tendrán recurso a los tribunales nacionales; solamente la adopción generalizada por la mayoría de los países de un sistema judicial bastante similar, la adopción de reglas similares establecidas de acuerdo a un tipo común correspondiente a un cierto grado de civilización, favorecerán grandemente el co-

(8) Acerca de la Comisión Europea a los Derechos det Hombre nos permitimas reenviar at lector a nuestro estudio aparecido en el "Annuaire Français de Droit International". 1957. pags. 449 a 477. 
mercio juridico internacional. Este es el momento de recordar la importancia de la codificación.

No es de extrañar que Alvarez se haya transformado, desde los comienzos de su carrera científica, en el campeón de la codificación. Junto con otro gran jurista latinoamericano, Bustamante y Sirven, fue el iniciador de este movimiento en favor de la codificación de las normas del derecho internacional privado en el mundo latinoamericano; si bien este movimiento todavía no ha concluido, es menester reconocer que se encuentra muy avanzado y que tanto entonces como ahora presenta resultados positivos que los países de otras partes del mundo harian bien en imitar.

b) El plano económico social. Desde otro punto de vista, la participación del hombre en el funcionamiento de las instituciones económicas o sociales surge con una mayor amplitud. Ciertamente estas instituciones son creadas por los Estados puesto que sólo ellos detentan el poder internacional, $\mathrm{y}$, por tanto, pueden crear instituciones de Derecho Público. Ustedes saben que los individuos han creado numerosas instituciones no gubernamentales, existiendo más de un mil, y que la Carta de las Naciones Unidas acepta que estas organizaciones no gubernamentales de interés general establezcan relaciones con la propia Organización de las Naciones Unidas y, especialmente, con el Consejo Económico y Social. Estas diversas instituciones, públicas o no, han sido creadas con el propósito loable de despojar a los problemas de las preocupaciones políticas irritantes y de confiar su solución a los hombres mismos. De esta manera nacieron primeramente los funcionarios internacionales, los cuales en la hora presente tienen tanta importancia y es tan grande su número y eficacia en la vida internacional, que en una gran medida y condición ella es realizada y dirigida por ellos. No necesito insistir acerca de la importancia del Secretariado de las Naciones Unidas, pero debo mencionar que cxisten numerosas otras agencias internacionales, en el plano mundial o regional, en las cuales inter- 
vienen los individuos que han sido seleccionados en razón de su competencia técnica y ubicados dentro de un estatuto internacional. En gran medida son hombres de Derecho Intcrnacional, individuos que se encuentran directamente bajo la ćgida dc este Derecho Internacional.

En fin, debe también mencionarse el caso de los individuos que no solamente actúan como tales en el plano del Derecho Internacional, sino que también responden de las consecuencias de sus actos. Pienso particularmente en las sanciones internacionales que pueden afectarlos hoy dia, en tanto que con anterioridad los hombres de Estado podían disimularse de una manera más o menos hipócrita, detrás del velo del Estado como persona moral y podían así atribuir al aparato estatal, en nombre del cual los habían cometido, los crímenes contra la humanidad, crimenes de genocidio, crímenes de guerra, que pululaban en todas las grandes operaciones de guerra.

El primer hombre que tuvo la categoría de sujeto del Derccho de Gentes fue de una participación muy notoria. Fue el pirata que, habiendo roto todos los vínculos con una soberanía determinada, fue prontamente dcclarado criminal del Derecho de Gentes. El pirata es el primer hombre que emergió al Derecho Internacional. No creo que deba rendirse homenaje al rol de pionero que tuvo el pirata que, si bien fue el primer hombre que rompió la opaca pantalla estatal, terminó colgado del palo más alto en su calidad de criminal. Es necesario que el hombre pucda emerger a la vida internacional quizás en una actitud menos pintoresca pero que, esta vez, le permita encontrar plenamente los caminos de su realización. A ello se está llegando.

c) La protección judicial. Algunos logros se están cumpliendo por medio de la acción judicial así como en el plano de la libertad política.

En el plano de la acción judicial hay ciertos logros que, como ustedes saben, permiten al individuo encontrarse cada día 
más como titular de una competencia judicial internacional, contrariamente a lo que ocurría antes.

Alvarez, en una opinión disidente vertida en el fallo de Ia Anglo Iranian Oil, del 22 de Julio de 1952, demuestra que la protección diplomática se ha renovado hoy día en gran medida y el Estado puede ejercer esta protección no solamente en contra de otro Estado, ante las instancias diplomáticas de ese Estado, sino también ante el Consejo de Seguridad de las Naciones Unidas, por ejemplo, o ante la Corte Internacional de Justicia. Pero agrega: "Estos aspectos de la protección diplomática sufrirán cambios cuando el nuevo Derecho Internacional establezca claramente los derechos del individuo, es decir, los derechos que éste pueda hacer valer directamente en contra de algún Estado sin recurrir a la protección diplomática del país del cual es nacional".

Precisamente, a partir del 3 de Septiembre de 1953, fecha de la entrada en vigor de la Convención Europea de Derechos del Hombre, vemos que el individuo puede presentar solicitudes individuales ante la Comisión Europea. Ciertamente esta no es la primera vez que se reconoce al hombre una competencia judicial internacional; ustedes conocen numerosos ejemplos, particularmente aquel de los Tribunales Arbitrales Mixtos o el de la Corte Centroamericana de Justicia creada en 1907. Sin embargo, la solicitud individual prevista por Ia Convención de Roma, en el marco europeo, surge como una institución particularmente progresista. Desde luego la Convención ha enunciado cierto número de derechos que los Estados signatarios tienen la obligación no solamente de respetar sino también de garantizar.

De esta manera resulta que hoy día en el marco europeo, los Estados que han ratificado la Convención -no todos la han ratificado- tienen dos posibilidades:

- Por una parte los Gobiernos pueden ejercer la protección diplomática ante la Comisión Europea de Derechos del Hombre. Pueden señalarle que las libertades fundamentales previstas en la Convención han sido desconocidas por un Es- 
tado determinado. $Y$ lo que es verdaderamente notable es que esta protección diplomática puede ejercerse inclusive respecto de un individuo que no es su nacional, en circunstancias que la regla clásica de la protección diplomática exigía que ella sólo puede ejercerse en favor de nacionales del Estado que la invoca.

- Por otra parte, los individuos mismos pueden manejar este derecho de petición individual y proseguir antc la Comisión Europea la satisfacción que descen obtener, particularmente lograr del Estado que ha adoptado una medida contraria a la Convención que la retire en su beneficio.

Estamos entonces en presencia de una situación que hace del hombre un verdadero agente de Derecho Internacional, un verdadero agente paralelo a los Estados preexistentes.

Precisemos que, para Alvarez, el individuo es un sujeto del Derecho de Gentes y hay suficientes hechos para que pueda sostenerse que el nuevo Derecho irá en el sentido de una multiplicación de los casos en que las competencias serán reconocidas al individuo, en el plano judicial o en otros planos. En el plano político cabe desde ya observar que intervicne ahora en determinadas asambleas que ya no son órganos interdiplomáticos, sino que, como las Asambleas europeas, son cámaras compuestas de individuos clegidos por sus Parlamentos nacionales y que sesionan ya no más como representantes de los Estados sino como representantes de un cierto ideal político; se agrupan además en bloques políticos según sus finalidades y en su voto - que tiene lugar individualmente y ya no más por delegaciones nacionales-se reparten entre mayorias y minorias que en sí mismas trascienden las divisiones de los Estados.

Todo esto irá multiplicándose: es para Alvarez incvitable o, si ustedes lo prefiercn, es el sentido de la historia que lo determina.

En Alejandro Alvarez esta visión del hombre como sujeto de Derecho Internacional está marcada por un gran realismo. Puede calificarse este realismo en dos proposiciones principales: 
- El individuo no es el único sujeto de Derecho de Gentes;

- es solamente un sujeto nuevo.

Al sostener que el individuo no es el único sujeto de Dc. recho de Gentes, Alvarez se aparta de las doctrinas idealistas como aquella de Nicolás Politis que ve en el individuo al único sujeto verdadero del Derecho de Gentes. Esta doctrina, muy generosa y humanista, estima que los Estados sólo son ficciones jurídicas y que el Derecho Internacional ha sido hecho para las colectividades humanas.

Por respetable que sea esta manera de apreciar ella no obedece exacta y fielmente a la realidad internacional; el Estado existe y no podría negarse esta existencia. El individuo es entonces un sujeto nuevo y es en esta calidad que aparece al lado tanto de los Estados como de los organismos internacionales; estos últimos, también nuevas personas en el Derecho Internacional.

B. La organización internacional como nuevo sujeto del Derecho Internacional

La organización intcrnacional también es una nueva persona del derecho de gentes. Alvarez desempeñó un gran rol en la Corte de Justicia de La Haya con ocasión de la opinión consultiva que ésta emitió el 11 de Abril de 1949 y que reconoció esta promoción.

Ustedes recordarán que una serie de trágicos incidente habían afectado a los agentes de las Naciones Unidas en el ejercicio de sus funciones, y particularmente al Conde Bernadotte, mediador de las Naciones Unidas que había sido asesinado por terroristas. Cuando un nacional de un Estado es víctima de un daño en el extranjero es el Estado de su nacionalidad el que ejerce la protección diplomática en su beneficio y solicita la reparación de los perjuicios ocasionados. 
El problema que se planteaba era el de saber si acaso una organización internacional podía por sí misma llevar a cabo esta protección respecto de uno de sus agentes, asimilándola a lo que el vinculo de nacionalidad es para el Estado, cuando era víctima de un perjuicio en el ejercicio de sus funciones.

Algunos jueces de la Corte Internacional en sus opiniones disidentes se opusicron no tanto al derecho de la organización de obtener una reparación, sino a su derecho de actuar ella misma para obtener tal reparación. Estos jueces rechazaron entonces la posibilidad de que tuviese una competencia de protección recordando que la protección diplomática existe en beneficio de los Estados.

Evidentemente en el Derecho Internacional clásico no se reconoce como sujeto del Derecho Internacional sino a los Estados; en estas condiciones la organización internacional -si se aplica este derecho tradicional - no puede ejercer una protección diplomática en favor de sus agentes.

Era este el momento preciso en que la Corte debía optar entre la aplicación estricta del derecho clásico, o por el contrario, adherirse al nuevo derecho. La Corte, en efecto, no siguió a los jueces mencionados y elaboró una noción muy coherente de la Organización Internacional como nueva persona del derecho de gentes.

Dos problemas se planteaban:

1) La protección funcional. En caso de daño sufrido por un funcionario de las Naciones Unidas, ¿tiene la organización calidad para presentar en contra del gobierno "de jure" o "de facto" responsable una reclamación con el objetivo de obtener una reparación, tanto respecto de los daños que se le han causado a ella misma como respecto de los perjuicios sufridos por los funcionarios? La Corte respondió afirmativamente.

Alvarez, en su opinión individual, la felicitó y precisó las razones que lo conducen a esta manera de pensar. El destaca 
que se trata éste de un problema nuevo; el antiguo derecho no podía proporcionar ninguna respuesta; la protección diplomática sólo existe en favor de los Estados y la Organización de las Naciones Unidas no es un Estado.

La Corte estimó que las Naciones Unidas ejerce respecto a sus funcionarios una protección funcional; y de esta manera, por medio de la noción de la protección funcional, desprendió un nuevo derecho, como desde luego lo destacó muy bien Madame Suzanne Bastid en su curso sobre jurisprudencia internacional en la Academia de La Haya en 1951.

Alvarez en su comentario toma en consideración los objetivos de las Naciones Unidas y adelanta que ésta no podría cumplir con tales objetivos que le han sido impuestos por la Carta si no se le reconocía esta competencia de ejercer tal protección. Ello lleva, desde luego, a la respuesta relativa al segundo problema.

2) Compatibilidad con el interés del Estado. Se preguntaba cómo, si se reconoce este derecho de la Organización Internacional, podía conciliarse su acción con los derechos del Estado del cual la víctima era nacional; cómo esta acción de las Naciones Unidas podía respetar o poner en juego los derechos del Estado.

En la opinión dc Alvarez no necesariamente se trata de que las Naciones Unidas actúen de acuerdo con el Estado del cual la víctima es nacional. Las Naciones Unidas puede actuar sola, sin necesidad de solicitar la autorización y sin incluso invitar al Estado a que lo haga. Las Naciones Unidas no tiene una competencia subsidiaria de intervención en defecto de la intervención del Estado; goza de un derecho propio. Sólo así se explican los problemas que podrían presentarse en aquellos casos en que la víctima sea apátrida o que el Estado, incluso no siendo apátrida, descuide la presentación de una reclamación por consideraciones políticas o de otra indole, o todavía que la víctima tenga la nacionalidad del propio país demandado. Para Alvarez el derecho de protección 
de las Naciones Unidas es un derecho autónomo que puede ser ejercido incluso cuando la víctima tenga la nacionalidad del país objeto de la reclamación, opinión enteramente contraria a la norma generalmente admitida respecto de la protección diplomática entre Estados, como fue recordado en 1955 en el caso Nottebohm por la Corte Internacional de Justicia; en principio la protección diplomática no puede ser ejercida en favor de un individuo que tenga la nacionalidad del Estado demandado. Respecto de las Naciones Unidas, Alvarez estima que ello es posible. ¿Cuál es la razón de una regla tan progresista? ¿Cuál es la razón de este privilegio de las Naciones Unidas? Simplemente porque las Naciones Unidas debido a su posición y a su función internacional, debe poder actuar en cl interés de la comunidad internacional. Desde el punto de vista de Alvarez se encuentra entonces ubicada en un terreno superior al de los Estados; la protección funcional de que ella dispone no podría asimilarse o reducirse a la proporción de la protección diplomática ejercida por el Estado, puesto que el Estado que la ejerce actúa en realidad sobre todo en su propio interés. Por el contrario, la protección funcional de las Naciones Unidas es utilizada en el interés de todos. Esta es la razón por la cual ciertas reglas que entre Estados impiden el funcionamiento de la institución no deben frenar la acción de las Naciones Unidas, puesto que está dirigida en beneficio del interés general.

Esta posición superior de la organización internacional es totalmente natural. Si bien esta situación privilegiada no debe extrañarnos, de todos modos debemos recordar que no existe una sola organización internacional en el mundo; que hay numerosas, lo que plantea otro problema: aquel de las relaciones entre las organizaciones internacionales. El derecho internacional clásico cra un derecho interestatal, en tanto que el nuevo derecho internacional no solamente plantea el problema de las relaciones entre los Estados y las organizaciones internacionales, sino que además el problema de las relaciones entre organizaciones. $Y$ este es un problema que se plantea so- 
Por otra parte, Alvarez subraya la existencia de un subregionalismo jurídico en el interior mismo del regionalismo. Insiste particularmente en la existencia de un derccho latinoamericano, en contraposición al derecho panamericano que también involucra a los Estados Unidos de América del Norte. Siempre ha existido en el hemisferio occidental un movimiento propiamente iberoamericano, que cuenta con principios de derecho internacional, cual es particularmente el régimen del derecho de asilo, que no ha sido admitido por los Estados Unidos de Norteamérica, sino que se encuentra en vigor únicamente entre las repúblicas latinas.

Por mi parte creo que incluso esta distinción puede llevarse más lejos todavía; puede alcanzarse el marco más estrecho de la subdistinción. Es así como si consideramos al hemisferio occidental veremos que desde el 14 de diciembre de 1951 existe una Organización de Estados Centroamericanos (ODECA) e igualmente entre Estados de América del Sur puede destacarse diversos sintomas de un subregionalismo especializado. Particularmente pienso en la Carta de Quito aprobada cl 9 de agosto de 1948 que crca una Organización Económica Grancolombiana encargada de llevar a cabo una unión económica y aduanera. Ustedes saben que la Gran Colombia originariamente estaba compuesta de los actuales países Ecuador, Colombia, Venezuela y Panamá.

El derecho internacional americano se encuentra por tanto relativamente estratificado. Bajo este vocablo genérico es menester considerar el derecho del Nuevo Mundo, el derecho internacional regional, que es el más rico de todos los derechos regionales porque es el más antiguo.

¿Por qué sostenemos que es el más rico y el más antiguo? Precisamente porque desde 1823 con la formulación de la doctrina de Monroe, los Estados del Nuevo Mundo reivindicaron su autonomía $y$, defendidos por la barrera que habían levantado entre el nuevo y el antiguo continente, pudieron preservar su vida jurídica interamericana la cual se desarrolló de esta manera libremente y al amparo de esta doctri- 


\section{A. El conflicto de derechos}

1. Existencia del derecho regional. La primera cuestión se refería a la existencia misma del derecho internacional americano y su reconocimiento por la Corte Internacional de Justicia.

En la actualidad el problema ya no merece dudas: el derecho internacional americano fue implícitamente reconocido por la Corte Internacional de Justicia en este asunto; pero Alvarez siempre observa que también existe, en grados variables de desarrollo, un derecho internacional de los países socialistas y un derecho internacional europeo que cada día se desarrolla más y que tiende a otorgar una unidad política al continente. Ya les he citado algunos ejemplos; podríamos igualmente recordar el caso de la Convención sobre la solución pacífica de controversia que fue adoptada en el marco del Consejo de Europa el año último. $X$, en fin, se dibuja también un derecho internacional asiático y un derecho internacional africano.

En el análisis del derecho internacional americano en su opinión disidente, a propósito del asunto del derecho de asilo, Alvarez escribe: "Por estos términos de derecho internacional amcricano es menester entender, no como podría creerse a primera vista y como lo han creído numerosas personas, un derecho internacional especial del Nuevo Mundo y enteramente distinto del derecho internacional universal, sino un conjunto de principios, convenciones, prácticas, instituciones y doctrinas, que son propios de las repúblicas del Nuevo Mundo". Ello le Ileva a una doble precisión. Por una parte, se trata de un derecho que vincula a las veintiuna repúblicas que constituyen actualmente la Organización de Estados Americanos, siendo menester no olvidar que Canadá, miembro de la comunidad británica, y las colonias europeas en el hemisferio occidental no han participado históricamente en la elaboración del derecho internacional americano. 
lamente en el nuevo derecho. En el antiguo derecho, se consideraba que los Estados se encontraban ubicados en un mismo pie de igualdad, soberanos e igualitarios.

Pero respecto de las organizaciones internacionales hay que formularse la pregunta de si acaso las relaciones entre ellas se plantean con la misma igualdad que entre los Estados. Se observa que algunas organizaciones son generales y agrupan a un gran número de Estados, la cuasi universalidad de los Estados; otras son de carácter regional o especializadas y no agrupan sino a un número más reducido de Estados. Es el segundo problema que Alvarez fue quizás el primero en estudiar en la doctrina.

2. La organización universal y las organizaciones regionales

Siendo Alvarcz el campeón del continentalismo, cabía esperar su intervención en el asunto del derecho de asilo, que concluyó con el fallo del 20 de noviembre de 1950 de la Corte Internacional de Justicia de La Haya; asunto que igualmente se conoce con el nombre del caso Haya de la Torre, nombre del dirigente peruano que se asiló en la embajada de Colombia.

Este problema junto con poner en discusión numerosos aspectos del derecho internacional presentaba, entre otros, el problema de la existencia del derecho regional, el derecho interamericano, que consagra ciertas normas -particularmente en el derccho de asilo- que no se encuentran de la misma manera en otras partes del mundo. Y también planteaba el problema de las relaciones entre este derecho regional y el derecho universal. Este problema se plantea en dos planos:

-El problema de las relaciones entre los derechos regionales y el derecho universal, es decir en el plano normativo.

- Y en seguida el problema de las relaciones entre las estructuras institucionales de las organizaciones regionales y de la organización mundial, en el plano constructivo. 
na. En mi primera clase les expliqué que la noción del derecho internacional americano era el equivalente en el plano del derecho a lo que Ia doctrina de Monroe había sido en el plano de la política. También les señalé que Alvarez, sosteniendo la originalidad juridica del continente, había manifestado un anticolonialismo jurídico; creo que, en esta medida, él es el precursor de todos estos movimientos a los cuales asistimos hoy día, particularmente los movimientos afroasiáticos o como algunas veces se les llama, el movimiento de Bandung. El derecho internacional de la época era un derecho internacional que Europa calificaba de universal e imponía a los demás continentes. Esta actitud pudo ser mantenida por Europa respecto de Asia y Africa, pero no pudo serlo respecto del Nuevo Mundo gracias a la doctrina de Monroe. Nació de esta manera el derecho internacional americano que fue el primero de los derechos regionales que reivindicó una existencia autónoma frente a un derecho europeo camuflado de derecho universal.

Actualmente presenciamos precisamente la misma reclamación por parte de los demás continentes. Destaco esta idea porque en este plano la doctrina de Alvarez tiene una importancia fundamental, derivada de su valor profético sobre lo cual no creo que sea necesario insistir.

Simultáneamente se plantea entonces el problema de las relaciones entre el derecho universal verdadero, es decir, ya no más de un derecho regional calificado abusivamente como universal, y los derechos regionales.

2. Relaciones entre el derecho universal y el derecho regional. Estas relaciones pueden enfocarse en dos maneras:

a) Desde un primer punto de vista puede sostenerse que el derecho universal prima siempre y en toda circunstancia sobre el derecho regional. Puede estimarse que existe una relación de jerarquía entre los dos. Es la opinión de los autores que enseñan la jerarquía de los ordenamientos jurídicos 
y particularmente de Georges Scelle, quien, en el asunto del derecho de asilo, era precisamente el conscjero del gobierno peruano. Este eminente autor ve en la existencia del derecho internacional americano, que en ningún momento niega, un fenómeno de descentralización jurídica internacional. La descentralización supone una cierta centralización en la cima y una subordinación de las colectividades territoriales en relación al poder central, en virtud de una doctrina que se inspira de la técnica federal tal como se expresa en la regla formulada por los jurisconsultos alemanes de comienzos de siglo: "El derecho federal prima sobre el derecho local".

b) Desde un segundo punto de vista, que es aquel de Alvarez, se estima por cl contrario que el derecho regional tiene un valor no de subordinación sino de equivalencia con el derecho universal, puesto que involucra un área de aplicación determinada y el derecho universal contiene solamente los principios comunes que han sido aceptados por las diversas regiones de la juridicidad.

Dicho de otro modo, el derecho regional sería preexistente al derecho universal en muchos casos. El derecho universal sería el punto de confluencia de una evolución que, pasando por los regionalismos, va del nacionalismo al internacionalismo global.

Puede observarse así que la dirección del pensamiento de Alvarez va cn una dirección exactamente inversa a la del de Georges Scelle, no obstante que él también invoca un proceso federal. Ambos autores no se sitúan en el mismo momento de este proccso. Georges Scelle razona sobre la base de una federación cxistente y ya avanzada en la cual el poder central, en efecto, se encuentra en situación de dominar a las partes componentes.

Alvarez considera, por el contrario, primeramente a las partes componentes; él se sitúa en el momento en que el proceso federal comienza a entrar en movimiento; la suya es una construcción federativa del derecho universal que resulta de la concurrencia de los derechos regionales y de su adhesión 
a los principios fundamentales hacia los cuales todos pueden convergir.

No debe parecer extraño que Alvarez permanezca fiel a esta segunda tesis, no obstante que, mediante la noción del derecho internacional americano, formuló una reivindicación de autonomía jurídica, que expresó un monroísmo jurídico respecto del derecho europeo. Para él las relaciones entre los derechos continentales y regionales con el derecho universal pueden resumirse en dos reglas:

-Por una parte, el derecho internacional continental obliga a todos los Estados del continente.

-Y por otra parte, en caso de conflicto entre el derecho internacional continental y el derecho internacional universal, es el primero que prima sobre el segundo. Es el derecho regional o continental que prima sobre el derecho universal; pero es menester precisar bien que ello es aplicable sólo en caso de un conflicto nacido y debiendo ser resuelto en la región o en el continente. En suma se trata de la aplicación del principio de la territorialidad del derecho.

Subordinación y correlación. Resulta así que, como lo escribió en su opinión disidente en el asunto del derecho de asilo, estos derechos regionales y el derecho universal no se encuentran en una situación de subordinación sino en una de correlación. De esta manera, nus dice Alvarez, el derecho internacional americano obliga a los Estados de otros continentes en aquellas materias que deben ser aplicadas en América, tales como Ia emigración, el jus soli para la nacionalidad, o bien como ocurrió en el comienzo de la guerra cuando el continente americano declaró su neutralidad y creó una zona de seguridad continental. En efecto, en la Reunión de Ministros de Relaciones Exteriores celebrada en Panamá en 1939 las repúblicas americanas decidieron la implantación de una zona de seguridad alrededor del continente, en el interior de la cual ningún acto de beligerancia debía producirse. Muchos Estados marí- 
timos, particularmente Gran Bretan̄a, protestaron contra esta pretcnsión haciendo valer que esta medida les era inoponible.

Para Alvarez la aplicación de esta medida no merecía duda puesto que el derecho se aplica territorialmente. En el hecho el problema de la zona de seguridad no se planteó por mucho tiempo; presentó algunas dificultades en el comienzo de las hostilidades pero luego fueron solucionadas cuando las repúblicas del hemisferio occidental ingresaron a la guerra.

El problema vuelve a plantearse hoy día en el nuevo derecho internacional a propósito de la plataforma continental.

Ustedes saben qué se entiende por esto. Partiendo de la costa existe una zona de profundidad que tiene la configuración de una verdadera plataforma y que sería la prolongación del continente bajo las aguas, una especie de continente sumergido. Esta plataforma continental está cubierta por un mar rico, particularmente en materia de pesquería. Por otra parte, su profundidad no impide la utilización de su suelo y de su subsuelo; ello reviste el más grande interés para los Estados ribereños puesto que esta plataforma continental muchas veces contiene importantes riquezas minerales y particularmente petrólco.

El descubrimiento de la plataforma continental necesariamente debía trastornar el derecho internacional clásico del mar. Este derecho siempre estuvo presidido por la idea de la utilización del mar como medio de comunicación: "El mar es un lugar de tránsito, una vía de comunicaciones". A partir de estos descubrimientos el mar surgió como un "tesoro"; suponía por tanto utilizaciones diferentes que no sólo se relacionaban con la navegación de itinerarios, sino que planteaba también el problema de la apropiación del suelo, del subsuelo e incluso de parte de las aguas.

Las repúblicas americanas han formulado reivindicaciones en este último sentido. El presidente Trumann en su célebre declaración de 1945 reivindicó la plataforma continental para los Estados Unidos de Norteamérica. El presidente Camacho de México formuló una reivindicación idéntica en la 
misma época. Luego hemos presenciado una especie de reacción en cadena de reivindicaciones de este tipo por parte de casi la totalidad de las repúblicas de América Latina. Incluso hemos visto Estados, como el caso de Chile, Perú y Ecuador -que si bien no tienen una plataforma continental en el sentido de que muy próximo a las costas se encuentran las profundidades abisales-, reivindicar de todos modos el equivalente de una plataforma continental y una zona marítima de 200 millas; ello nos sitúa muy lejos de la vieja norma de las 3 millas del derecho internacional clásico que, por otra parte, no era universalmente admitida.

En la actualidad, en el momento en que les hablo, se reúne en Ginebra una conferencia internacional que procura codificar los problemas del derecho del mar, los cuales son, es menester reconocerlo, problemas de nuevo derecho en el sentido de que Alvarez empleó esta expresión.

Así tenemos que la plataforma continental plantea hoy dia dificultades. Puedo indicarles que ya tenemos numerosos cursos y escritos sobre estos problemas; encuentran ustedes en las colecciones de cursos de la Academia de La Haya enseñanzas que se refieren frecuentemente a los mismos, algunos de los cuales estudian la cuestión bajo todos sus aspectos; no es este el lugar de darles una bibliografía; simplemente quisiera recordarles, entre otros artículos muy importantes, aquel de Kunz en el "American Journal" de 1956, el estudio de Georges Scelle en la "Revue Générale de Droit International Public" en 1955 - "Plataforma Continental y derecho internacional"-y el artículo de J. M. Yepes - "Las nuevas tendencias del derecho internacional del mar y el derecho internacional americano"- publicado en la misma revista en 1956.

En la actualidad este problema presenta dificultades internacionales puesto que la regla de la plataforma continental puede ser considerada como una regla del derecho internacional americano. En efecto todos los Estados del Nuevo Mundo han reivindicado la plataforma continental. Este conjunto de declaraciones unilaterales revela la adhesión de cada uno de 
los países a una norma regional. Por otra parte, algunas convenciones internacionales ya han sido celebradas; pienso particularmente en la Convención Tripartita de Santiago aprobada en agosto de 1952 por parte de Chile, Ecuador y Perú.

Hay naves que enarbolan el pabellón de Estados que no han reconocido la noción de plataforma continental, que navegan en los mares epicontinentales de estos países de América Latina y que violan la legislación que estos paises ribereños han dictado respecto de las aguas suprayacentes a la plataforma continental, particularmente la reglamentación de pesca. $¿$ Cuáles son las razones que han llevado a estos Estados a Ia reivindicación de la plataforma continental? Por una parte ello tiene por objeto utilizar las riquezas del suelo y del subsuelo marino, así como utilizar y proteger las especies contra una destrucción masiva, pues estas especies representan, entre otros intereses, aquel de permitir una lucha más eficaz contra el hambre. Así tenemos como en 1955 se produjo un incidente muy grave en las aguas epicontinentales peruanas entre las flotas del armador Onassis y las autoridades marítimas y aeronáuticas del Perú. Onassis tiene una flota ballenera que desarrolla una caza muy próspera en estos parajes, industria que, desde el punto de vista del derecho internacional clásico, es perfectamente legítima. Por el contrario, si se aplica el derecho internacional nuevo y regional americano ya no podrá considerarse que tiene el derecho a hacerlo. Sus navíos fueron apresados cuando se encontraban lejos del mar territorial, más allá de la zona contigua incluso. Las autoridades ribereñas condujeron a estos navios por la fuerza a los puertos peruanos y aplicaron fuertes multas al armador.

Debo omitir otras dificultades que se han presentado pues son numerosas. Nos encontramos pues en el centro de un problema del nuevo derecho internacional $\mathrm{y}$, más precisamente, de un problema que plantea las relaciones de este derecho regional, el derecho americano que admite la plataforma continental, y los demás derechos que no la admiten. ¿Equivale lo anterior a decir que es el derecho universal el que no la ad- 
mite? No podríamos estar seguros pues hay muchos otros Estados que no pertenecen al hemisferio occidental pero que también rcivindicaron sus plataformas continentales; cabe mencionar el caso de los Estados árabes del Golfo Pérsico así como el de Indoncsia, que acaba de presentar a este respecto reivindicaciones sumamente espectaculares.

Mantengámonos, sin embargo, en el marco preciso del problema que hemos planteado: Las relaciones del derecho continental o regional con el derecho universal.

Para Alvarez todo navío que enarbole el pabellón de un Estado que no reconoce la plataforma continental, debe de todos modos respetarla si navega en las aguas epicontinentales de un Estado americano, pues es su deber respetar la reglamentación relativa a la utilización de cstas aguas. El derecho regional se aplica a todos los Estados del mundo que de una $u$ otra manera operan en el interior de la región; es la noción de la territorialidad del derecho.

Lo anterior no debe parecernos tan chocante como pudiera pensarse. Desde hace tiempo que la doctrina ha observado que la reglamentación internacional de territorios tiene un valor objetivo que se impone a todos los Estados; es particularmente el caso de los tratados territoriales los cuales, contrariamente al derecho común de los tratados, tienen uil efecto no solamente entre las partes sino también "erga omnes". Puede pensarse en la Convención de Montreux sobre el régimen de los estrechos no fue firmada por todos los Estados del mundo, lo que no impide que todo navio que circule por estos lugares deba acatar el régimen de la Convención. Los tratados que establecen un estatuto territorial tienen un valor objetivo que se aplica a todos, hayan o no participado en la elaboración de la Convención, desde cl momento en que desearan utilizar el territorio y someterse así a este estatuto. Mayor razón para que ello sea así respecto de un derecho regional continental que, también él, se refiere a in estatuto territorial. 
Reencontramos pues la idea de la autonomía del derecho que responde a condiciones sociales particulares. Pero así como el derecho regional en el plano normativo, en el plano de las reglas, guarda esta independencia, ¿es posible decir lo mismo de la organización regional en sus relaciones con la organización de vocación universal?

\section{B. Relaciones entre las organizaciones internacionales}

Esta vez ya no se trata de relaciones entre derechos sino entre poderes.

Es un problema de relaciones de estructuras. Alvarez se preocupó de este problema desde Ia época de la Sociedad de las Naciones. Veamos primeramente cómo él lo abordó en esa época.

1) Relaciones con la Sociedad de las Naciones. En to que respecta a las relaciones entre la Unión Panamericana y la Sociedad de las Naciones, Alvarez se mostraba sorprendido por la pretensión de esta Sociedad en Ginebra de presentarse como una sociedad universal. Verdaderamente no lo era y este implacable realista desenmascaró una ficción más. Los Estados Unidos no habían ingresado; otros Estados importantes del mundo tampoco lo habían hecho y ella tendía cada día más a reducirse a una sociedad de naciones europeas. Con el propósito de defender al sistema interamericano deseó actuar en dos planos: primeramente hacer de la Unión Panamericana una verdadera sociedad de naciones del continente americano, es decir, aumentar sus poderes que en la época eran sumamente reducidos. Ya les he mencionado el importante rol que Alvarez jugó a este respecto; les indiqué las resoluciones que contribuyó a aprobar en la $\mathrm{V}$ Conferencia Panamericana; y también su influencia en la Convención del 12 de febrero de 1928 de La Habana, que estableció la Carta que 
habría de regir al sistema interamericano en su funcionamiento entre 1928 y 1948, fecha esta última en que se estructuró como Organización de los Estados Americanos que es una organización regional perfecta y de plena competencia. Ustedes saben el rol considerable que el pensamiento de Alvarez jugó en esta evolución y en esta construcción de las instituciones interamericanas.

En un segundo plano, Alvarez estimaba que la Sociedad de Naciones debía perder esta reputación de sociedad universal que no merecía y aparecer simplemente como una verdadera organización europea. Consideraba que no era necesario modificar la estructura de la Sociedad de las Naciones para permitir el ingreso de los Estados Unidos, como se había propucsto, sino simplemente crear un vínculo cntre la institución de Ginebra, reducida a sus verdaderos propósitos, y la institución de Washington, la institución interamericana; un vínculo entre estas dos organizaciones situadas en un pie de igualdad.

Observen ustedes que esta idea todavía se encuentra presente en la actualidad. En efecto, debido al declinar de la Organización de las Naciones Unidas, los entendimientos regionales y los pactos de defensa se han multiplicado; el mundo occidental se agrupa hoy día en la Organización del Tratado del Atlántico Norte compuesto por quince Estados del Antiguo y del Nuevo Mundo, este último representado por los Estados Unidos y Canadá. El Presidente Prado del Perú propuso, en diciembre de 1957, el establecimiento de vínculos entre la Organización de Estados Americanos y la OTAN -podía hacerse pues se trata de dos organizaciones que no se encuentran en situación de subordinación sino en una de correlación-, organización esta última que en cierta medida ha reemplazado a la impotente Naciones Unidas en una parte del mundo libre, al menos en lo que respecta a los problemas de defensa militar. Esta proposición del Presidente Prado recibió una favorable acogida de parte de la OTAN y en el momento actual se encuentra bajo estudio. 
Este plan se inspira directamente en la vieja idea de Alvarez en 1928 cuando proponía un vinculo entre la Unión Panamericana y la Sociedad de las Naciones, idea que entonces fue muy combatida pero que finalmente, por la fuerza de los acontecimientos, terminó por ser adoptada tanto por las Conferencias Panamericanas como por las Asambleas de la Sociedad de las Naciones en 1933.

Esta reivindicación de autonomía del sistema regional interamericano en relación a la Sociedad de las Naciones no ha dejado de guiar a las repúblicas latinas, como bien se vio en 1945.

2) Vínculos con las Naciones Unidas. En el momento de la preparación de la Carta de las Naciones Unidas se celebró una conferencia en Dumbarton Oaks que elaboró diversas proposiciones. Estas que eran sólo un proyecto de Organización de las Naciones Unidas, no daban lugar a un regionalismo. En ese momento se vio cúmo todas las repúblicas latinas animadas de un sentimiento de defensa se agruparon para imponer la aceptación por parte de la Organización de Naciones Unidas en preparación, de la existencia del más viejo de los regionalismos juridico-políticos, el regionalismo interamericano. Lucharon por una reivindicación que se inspiraba directamente en todo aquel movimiento cuya señal de partida habia dado Alvarez en 1910. Y ganaron; las repúblicas latinas lograron la incorporación del artículo 51 en la Carta que prevé el derecho de legítima defensa individual o colectiva, que puede ser ejercido por los Estados hasta tanto que el Consejo de Seguridad no haya adoptado las medidas necesarias para restablecer el mantenimiento de la paz y de la seguridad internacional.

A propósito de la Organización de Estados Americanos, Alvarez lamenta que el artículo $1^{\circ}$ de la Carta de Bogotá de 1948 prevea que la Organización de Estados Americanos exista dentro del marco de las Naciones Unidas. Hubiera preferido que clla disponga de una mayor libertad de acción frente a 
las Naciones Unidas. Pero interpreta restrictivamente sus alcances, particularmente en su opinión individual en el caso del derecho de asilo.

En efecto, estima que la Organización de Estados Americanos, como toda otra organización regional, no se encuentra subordinada a las Naciones Unidas sino en aquellas materias que se refieren al mantenimiento de la paz y de la seguridad internacional. Fundamenta esencialmente su opinión en argumentos derivados del texto y en argumentos derivados de la intención de estos instrumentos.

-Un argumento derivado del texto: El artículo 52 de la Carta de las Naciones Unidas se refiere únicamente a los problemas del mantenimiento de la paz y de la seguridad, los cuales, en principio, en la redacción de la Carta, ya que no en la práctica actual de las Naciones Unidas, eran monopolizados por el Consejo de Seguridad. Es, entonces, únicamente respecto de estas cuestiones relativas al mantenimiento de la paz que las organizaciones regionales se encuentran subordinadas a las Naciones Unidas.

En cambio para las demás cuestiones ellas pueden desarrollarse en toda libertad y adoptar las resoluciones con entera independencia. Es el caso de la Organización de Estados Americanos que no ha dejado de adoptar recomendaciones o convenciones sin haber recurrido a las Naciones Unidas; ello está totalmente de acuerdo con el derecho positivo. Lo mismo es también cierto respecto de los países socialistas que continúan desarrollando cntre ellos sus relaciones y elaborando textos con entera libertad.

Resulta así enteramente normal que Alvarez reduzca la superioridad jerárquica de las Naciones Unidas en relación a las organizaciones regionales, a los problemas del mantenimiento de la paz y de la seguridad.

-En cuanto al argumento derivado de las intenciones de estos instrumentos, sostienc que la intención de la Carta de las Naciones Unidas era poner los problemas de la paz y de la seguridad en el primer plano de las preocupaciones de la 
Organización. La Carta quiso encontrar una solución a estos problemas, pero en relación a los demás se demostró liberal y no habria ninguna razón ahora para tratar de aplicarla en forma más estricta.

Si se desea vivir lejos de las ficciones, como Alvarez siempre lo recomendó, debe reconocerse que incluso esta subordinación de la Organización de Estados Americanos y de otros organismos regionales a las Naciones Unidas, en el cuadro restringido del mantenimiento de la paz y de la seguridad, es bastante reducida y de escasa coacción. En efecto, se prevé por la Carta de las Naciones Unidas -es el sentido del artículo 51 que los latinoamericanos lograron en su sostenida lucha en Ia Conferencia de San Francisco- que los entendimientos regionales pueden, en caso de una agresión armada en contra de uno de sus Estados miembros, desencadenar una acción fundamentada en la legítima defensa y proseguirla hasta tanto el Consejo de Seguridad no haya adoptado medidas sobre el particular. Y como es muy probable que el Consejo de Seguridad resulte paralizado por el derecho de veto impidiéndosele la adopción de las medidas en el asunto, el acuerdo regional podrá siempre continuar con sus acciones y en definitiva será él quien se encargará de salvaguardar la paz y la seguridad.

\section{Sección II}

\section{LAS MODYFICACIONES DEL DERECHO INTERNACIONAL DESDE EL PUNTO DE VISTA DE SU FINALIDAD}

Estas modificaciones son evidentemente la consecuencia de los trastornos que la propia sociedad ha sufrido.

Alvarez desarrolló una sistematización de esta oposición entre el derecho internacional clásico, antiguo, y el nuevo derecho internacional. 
El derecho de gentes de los siglos XVIII y XIX, que tomó su forma definitiva a comienzos del siglo XIX, descansaba sobre las siguientes bases esenciales, que eran consideradas como intangibles:

- Todas las rclaciones internacionales estaban sujetas al Derecho Internacional con exclusión de todo otro elemento, particularmente de la política que era separada drásticamente del campo jurídico. De esta manera el mismo derecho internacional se ubicaba dentro de un marco muy preciso y muy estrecho; comprendía dos grandes partes prácticamente iguales: el derecho de la paz y el derecho de la gucrra.

-Este derecho era individualista por cuanto no consideraba más que el interés individual de los Estados. Sólo se preocupaba de delimitar los derechos de los Estados de acucrdo a sus intereses respectivos y no se preocupaba de manera alguna del interés general de la colectividad internacional, superior a aquel interés particular de los Estados. Como consecuencia de lo anterior este derecho era, como lo dijo Alvarez de una manera curiosa, "esencialmente jurídico", es decir, que se fundaba sobre una noción de justicia absoluta más o menos abstracta; estaba además muy influenciada por el derecho interno y por el derecho civil; era un derecho que descansaba sobre obligaciones de derecho estricto como se dice en derecho romano. Su aplicación y desarrollo descansaban en la lógica sin que se tomaran en consideración las consecuencias que podían derivarse en el orden social e internacional. Cada Estado aparecia en la colectividad provisto de sus derechos, y el derecho internacional mismo sólo tenía por objeto una delimitación de cada uno de estos derechos.

-En fin, el derecho internacional, calificado arbitrariamente como universal, era prácticamente estático, es decir, que sufría muy pocos cambios y que se componía de un cuerpo de reglas muy preciso, estrictamente determinadas y aplicadas. Cabe observar que se trataba de un cuerpo de normas muy pequeño, puesto que el derecho internacional jamás ha 
presentado un volumen normativo comparable al del derecho interno.

Hoy día, en la opinión de Alvarez, estas bases fundamentales se encuentran totalmente invertidas. Si tomamos los tres puntos indicados llegaremos a tres fórmulas totalmente inversas.

1) Carácter interdisciplinario de las relaciones internacionales. Hoy día es inexacto que todas las relaciones internacionales estén sometidas a reglas jurídicas. Numerosas de estas rclaciones, algunas muy importantes, no son susceptibles de serlo y se encuentran sometidas a otros elementos que las rigen, como la política, las fuerzas morales e incluso las fuerzas materiales. Es efectivo que se ha condenado el uso de la fuerza, pero a pesar de csta condenación la fuerza continúa produciendo efectos jurídicos. Los produjo después de la segunda guerra mundial y los sigue produciendo hasta nuestros días.

Sin embargo esta fucrza se manifiesta en condiciones muy curiosas, múltiples, que ya no permiten hacer descansar al derecho internacional en la gran distinción clásica utilizada por Grocio, "el derecho de la paz y el derecho de la guerra". Todavía vivimos, por ejemplo, en un período que se ha llamado de la "guerra fría". Si se trata de descubrir cuál es el significado de esta guerra fría en el derecho internacional, me parece que ella se caracteriza: primero por no ser una guerra; y segundo, por no ser fría.

En primer lugar no se trata de una guerra, pues el régimen del derecho de la guerra, tal como fue elaborado en el derecho internacional clásico y tal como fue reglamentado por las Convenciones de La Haya, no se encuentra en vigor a propósito de la guerra fría, la cual se manifiesta por procedimientos hostiles que no desencadenan la aplicación del régimen jurídico del derecho de la guerra.

Por otra parte, tampoco es fría en el sentido en que en muchos lugares de la tierra hay operaciones de fuerza, ope- 
raciones inclusive militares. Ha habido asuntos como el de Indonesia que continúa hoy día de una manera muy diferente que aquella de 1946 ó 1947; ha habido asuntos como el de Corea, Indochina, Birmania y otros. No se puede sostener que sea una guerra fría cuando frecuentemente se recurre al calor del fuego. Su única limitación es que todavía no provoca la participación directa y personal en el conflicto de los dos Estadios que podrían producir una conflagración mundial. Pero ello no impide que, en los numerosos puntos de la tierra en que se desarrolla por interpósitas personas, sea bastante candente.

En estas condiciones el derecho de la guerra no puede aplicarse en la actualidad. Cuando ha habido verdaderas guerras, como la primera y sobre todo la segunda guerra mundial, ha sido desconocido por una razón fundamental: la guerra surgió en una sociedad internacional trastornada e interdependiente y adoptó caracteres totalitarios que nunca antes habia tenido en la época en que la colectividad internacional era compuesta por Estados yuxtapuestos, y en que los conflictos podían localizarse y naturalmente se localizaban.

Por otra parte existe un gran número de situaciones, las cuales sin depender del derecho de la paz tampoco provocan en la actualidad la aplicación automática del derecho de la guerra.

Es menester reconocer, entonces, que la gran distinción de Grocio se encuentra hoy día en gran medida sobrepasada.

2) Carácter amplio del derecho internacional contemporáneo. El derecho de gentes ya no es individualista como el derecho clásico. Comienza a fundamentarse, según Alvarez debe hacerlo muy precisamente, en el régimen de interdependencia, que comenzó a surgir a mediados del siglo XIX.

De csta manera, el derecho internacional debe proponerse no solamente la delimitación de los derechos y los intereses de los Estados, sino sobre todo su armonización, a la vez 
que tomar en consideración el interés gencral, que es lo que no ocurria precedentemente.

De ahí que, en la opinión de Alvarez, el derecho internacional ya no sea solamente "jurídico", dada la complejidad de las relaciones internacionales; debe, según nuestro autor, tener un carácter político, económico, social y sicológico. Esta es la única manera de cvitar que sea sobrepasado por la política y de que pueda tomar en consideración todos los aspectos de los problemas que se presentan. Alvarez piensa particularmente, y frecuentemente invoca este ejemplo, en el asunto del Canal de Suez en el cual se confrontaron preocupaciones derivadas del antigio derecho y otras que, por el contrario; se inspiraron en el nuevo derecho.

3) Dinamismo del nuevo derecho internacional. En fin, el nuevo derecho internacional es esencialmente dinámico $\mathrm{y}$ ya no estático, es decir, que sufre cambios considerables porque es el derecho de una sociedad muy integrada y muy amalgamada; en estas condiciones su objetivo esencial no es delimitar los derechos de los Estados sino que tomar en consideración la conciencia jurídica de los pueblos y proseguir la satisfacción de sus necesidades.

Pueden ustedes apreciar en este rápido cuadro que les he esbozado los rasgos fundamentales que oponen al derecho clásico con el derecho nuevo.

Deriva de lo anterior que el nuevo derecho internacional obedece estrictamente a las modificaciones de la colectividad internacional y que, desde el punto de vista de su finalidad, presenta caracteres que recogen los rasgos de la nueva colectividad internacional.

Debo recordarles que cuando examinamos las modificaciones de la colectividad internacional les expliqué aquellas que se habían suscitado respecto de su naturaleza y de su espíritu, y particularmente:

-Es una sociedad de Estados y ya no más una simple yuxtaposición; 
- La sicología de los pueblos juega un papel importante allí donde antaño intervenía solamente la acción de los diplomáticos;

- Siendo el mundo más pequeño, sus partes componentes son más interdependientes las unas de las otras, pero esto mismo determina que las divergencias que separan a las diversas familias internacionales tengan una repercusión más grave.

Son estas tres modificaciones de la colectividad internacional las que vamos a encontrar nuevamente ahora en su proyección sobrc la evolución del derecho internacional. Por nuestra parte observaremos, como Alvarez nos invita, que el derecho internacional es el derecho de una sociedad.

-En primer lugar se encuentra lo que él llama el derecho de interdependencia social.

- En segundo lugar paralelamente a la intervención de la sicología de los pueblos en la sociedad internacional, las relacioncs entre la política y cl derccho internacional se plantean en nuevos términos.

-Y finalmente, en forma paralela al tercer rasgo de la evolución de la colcctividad internacional, que busca un cierto interés gencral que permita reunir a las familias internacionales todavía separadas, vercmos que el nuevo derecho internacional tiene una finalidad fundamental: la justicia social internacional y ya no más, como ocurría antes, la simple repartición de los derechos entre los Estados.

\section{El derecho de interdependencia social}

El derecho de interdependencia social es el derecho de una o varias sociedades internacionales, ya sean globales, regionales o locales, y ya no es más el derecho de una colectividad que está constituida por Estados yuxtapuestos. No es este un derecho que se preocupa de repartir a cada uno su parte de intereses jurídicamente protegidos, no es un derecho 
que reparte los intereses subjetivos de los Estados, sino un derecho coordinador y que persigue por sobre los Estados el interćs general de la sociedad de los Estados.

De esta manera Alvarez fundamenta el nuevo derecho en la noción de interdependencia social, noción que ya tuvimos oportunidad de examinar a propósito de los trastornos de la colectividad, y según la cual hoy día todas las partes se encuentran ligadas en un común destino.

Alvarez insiste cn esta idea de interdependencia social en todas sus opinioncs disidentes desde 1948 hasta 1955. La principal consecuencia que deriva de este derecho de interdependencia social, en la medida en que se le considera como el derecho de una sociedad, es que provoca el declinar de la noción de soberanía y del individualismo estatal.

\section{A. Es el derecho de una sociedad}

Alvarez ha expucsto cste punto de vista en diversas oportunidades. En su última opinión disidente antes de abandonar la Corte de La Haya, a propósito de la opinión consultiva que fue emitida por este alto tribunal en 1954 respecto de los efectos de los fallos del tribunal administrativo de las Naciones Unidas, escribe: "Hasta las dos últimas guerras mundiales todos los Estados formaban una simple comunidad; no existian entre ellos otros vínculos que aquellos que habían libremente aceptado. Después de cse momento, esta comunidad se ha transformado en una verdadera sociedad que engloba todos los Estados del mundo y esta transformación se ha efectuado sin que ninguna convención o acto solenne haya sido necesario para consagrarla". Y agrega: "Todos los pueblos comprenden que ya no están más aislados y que no solamente están ligados por actos que han aceptado libremente; son parte de una verdadera sociedad y, sobre la base de este hecho, el nuevo derecho internacional ha establecido un orden jurídico creando derechos y obligaciones que los Estados no tenían antes y 
sin que para ello se le haya solicitado la opinión a los Estados". Dos observaciones deben formularse a este respecto:

1) Nacimiento del nuevo derecho internacional. Para Alvarez el nuevo derecho internacional es un fenómeno de generación espontánea; no supone un tratado. El mismo expresa: "No es necesario que las obligaciones del nuevo derecho internacional hayan sido establecidas mediante un texto; estas obligaciones surgen de las exigencias mismas de la vida social". De esta manera resulta que son las necesidades presentes de la vida internacional las que han dado nacimiento a una nueva juridicidad, sin que los propios sujetos principales de derecho, que son los Estados, se hayan apercibido siempre de este fenómeno. Es precisamente de este hecho que se deriva la oposición entre el derecho internacional clásico, que los Estados creen todavía frecucntemente en vigor, y el nuevo derecho internacional, acerca del cual hay numerosos sintomas que no siempre se traducen en una suficiente conciencia (9).

Lo anterior revela igualmente un declinar del voluntarismo jurídico puesto que en el derecho internacional clásico el Estado no se encontraba vinculado sino en la medida de su voluntad, individual o colectiva, de someterse a una norma jurídica internacional, ya sea mediante un acto de voluntad expresada en un tratado o ya sea en virtud de un acto de voluntad tácita de origen consuetudinario, para lo cual también

(9) E1 nuevo detecho es reivindicado por algunos Estados en ciertos puntos que le son de conveniencía, en tonto que otros niegan a estas reivindicaciones todo valor juridico y se atienen a las reglas antiguas. Algunas veces todavía -y entonecs el problema es insolucionable- asistimos a un enfrentaniento de pretensiones fundadas sobre una concepción juŕdica respetada en una cierta región del munda $y$ por ciertos pueblos, y aquillas que derivan de tradiciones opuestas $\mathbf{z}$ más antiguas. Tal es el caso de los malentendidos ectuales entre for Estados antiguos, los cuales invocan el derecho clásico nacido del mundo occidental y los nuevos Estados que frecuentemente rechazan sus reglas. El derecho internacional en esta hipótesis debería cons. tituir la sintesis de dos nociones en opusición en la medida en que ella sea posible, lo que no siempre es: el problema del mundo precisamente es de saber si acaso podrá lograr un acuerdo mínimo acerca de las normas y de las palabras que las expresan. 
los voluntaristas analizaban el fenómeno recurriendo a la teoría de la expresión tácita de la voluntad.

2) Derecho y organización internacional. Al sostener Alvarez que el nuevo derecho internacional nació a la vida de una manera espontánea, agrega que ello no supone necesariamente la cxistencia de una organización internacional. Para él, el derccho internacional existe por sí solo, y no es indispensable la creación de un organismo internacional (SDN, ONU, OEA, o cualquier otro) para dar nacimiento a este nuevo derecho internacional. La organización internacional crea el nuevo derecho, pero éste también puede nacer al margen de ella.

Creo que a este respecto de todos modos es necesario hacerse algunas preguntas. En efecto, podemos en doctrina concebir dos maneras de oponer el derecho clásico al nuevo derecho. Desde luego se puede sostener que el uno deriva de tiempos pasados y el otro de tiempos presentes, este último referente tanto a las relaciones interestatales como a la organización internacional. Por otra parte, puede pensarse igualmente en la oposición del derecho clásico de la sociedad interestatal —que yo personalmente llamaría la sociedad de relaciones- con el derecho institucional de las sociedades estructuradas e incorporadas en organizaciones internacionales.

Personalmente me inclino por esta distinción. Por mi parte, opongo efectivamente dos derechos: un derecho internacional de relaciones, que es un derecho de una sociedad compuesta por la yuxtaposición de Estados --el derecho clásico si ustedes quieren llamarlo-, de relaciones porque es un derecho que está esencialmente hecho para permitir a los Estados establecer relaciones entre ellos, y el derecho de la sociedad institucionalizada.

Este derecho de relaciones presenta 3 caracteres:

- En primer lugar el poder se encuentra diseminado.

- En segundo Iugar el poder es incondicionado.

- Y en tercer lugar el poder tiende a la dominación. 
En primer lugar cabe observar que el poder se encuentra diseminado por cuanto pertenece a todos los Estados, en lugar de concentrarse en una sola autoridad superior, diseminación que cubre toda la superficie de la tierra.

Sostencmos también que el poder es incondicionado en el sentido de que el Estado es soberano y no reconoce ninguna autoridad que le sea superior. Todas las instituciones del derecho intennacional clásico, como por ejemplo el reconocimiento, lo demuestran muy bien. El reconocimiento de un Estado o de un gobierno es el acto discrecional por el cual un Estado accpta establecer relaciones con otro Estado. Ello es parte del corazón mismo del derecho de relaciones. El no reconocimiento no significa, como frecuentemente se cree, que niega la existencia del Estado del cual rechaza este reconocimiento. Es imposible en la actualidad negar la existencia de China democrática de Mao Tse Tung, cualesquiera que sean los sentimientos que tengamos respecto de este régimen; al igual que cs imposible negar la existencia del gobierno del general Franco en España cualesquiera que sean las opiniones que podamos tener respecto del régimen franquista. Pero los Estados se esfuerzan en establecer sus relaciones sobre la base de criterios políticos.

En fin, sostenemos que el poder tiende a la dominación precisamente porque en el plano horizontal de una colectividad de relaciones la igualdad de derecho de los Estados resulta cvidentemente contradicha por su inigualdad de potencia -militar, económica y otras-; todo el derecho internacional clásico reconoce el recurso a la fuerza, siendo el derecho a la guerra su más evidente consagración, así como igualmente todas las demás instituciones del derecho internacional clásico, cual es el caso del protectorado colonial, de la conquista y de la ocupación, son instituciones de dominación.

El derecho institucional. Por el contrario, opuesto a este derecho de relaciones creo yo que se encuentra el derecho de la sociedad organizada o el derecho institucional, cl cual pre- 
senta tres características diametralmente opuestas a las precedentes:

En primer lugar el poder ticnde a su concentración y ya no más a su diseminación. Las tentativas de concentración pueden darse en las estructuras de organizaciones mundiales -Consejo de Seguridad-, regionales - Consejo de la Organización de Estados Americanos-, o especiales - como la Alta Autoridad de la Comunidad Europea del Carbón y del Acero, por ejemplo-. En todas las estructuras institucionales internacionales podemos encontrar múltiples ejemplos de estas tendencias hacia la concentración del poder, más o menos vigorosa y con mayor o menor éxito. Según el grado de solidaridad de los Estados que forman la base de estas organizaciones nos encontraremos en presencia de una concentración mayor $o$, por el contrario, más rebajada.

En segundo lugar, el poder se encuentra condicionado. La sociedad institucional no se diluye en el plano horizontal como en la sociedad de relaciones, sino por el contrario se eleva en un plano vertical y en una estructura de poderes que, en una cierta medida, como consecuencia de la división de competencia entre los Estados miembros y la organización, reconoce a esta última una cierta autoridad sobre sus miembros. Evidentemente hay una línea de separación de las competencias que es aquella que determina el ámbito de la jurisdicción doméstica, particularmente el artículo $2 \mathrm{~N}^{0} 7$ de la Carta de las Naciones Unidas, y el ámbito que pertenece al poder de la organización.

En tercer lugar, y debido a que la organización también tiende a condicionar a los Estados miembros, el poder en principio ya no puede tender a la dominación, es contenido. Esta contención se observa desde luego en el plano normativo pues se ha renunciado al uso y a la amenaza de la fuerza, particularmente por la norma del artículo 2 No 4 de la Carta, norma que igualmente se encuentra en otras organizaciones internacionales como la Organización de Estados Americanos, la Organización del Tratado del Atlántico Norte y como el 
Pacto de Varsovia entre las democracias socialistas. Por otra parte, existen procedimientos que pueden llegar hasta la acción coercitiva para restablecer el orden público internacional si se encuentra amenazado por un Estado miembro o no miembro de la organización.

Nos encontramos entre dos sociedades que derivan de principios absolutamente opuestos. Ciertamente la sociedad institucional está lejos de ser perfecta; en su evolución hacia la concentración del poder, hacia el condicionamiento del poder, hay numerosas etapas que sobrepasar y todas las organizaciones no lo han hecho de la misma manera; pero, en el plano de la técnica jurídica, estas dos sociedades se inspiran en principios opuestos.

Desde este punto de vista, que me permito presentarles. la frontera entre los dos derechos (el derecho antiguo y el derecho nuevo) es una frontera institucional, pues se estima que no hay verdaderamente un derecho nuevo sino en la medida en que se integra centro de un aparato o dentro de una maquinaria institucional capaz de constatarla, constatación que debe tener la suficiente fuerza como para obligar a todos los sujetos de derecho.

Ello supone igualmente la opinión de que el derecho nuevo, en la medida en que permanezca al margen de una sociedad institucionalmente organizada, existirá quizás al nivel de conciencia jurídica pero le faltará su sanción; la formulación misma de este derecho puede resultar insuficiente y Ios Estados podrán continuar operando sobre la base del antiguo derccho, aunque esté obsoleto, más que desear recurrir a nuevas reglas.

Dentro de esta apreciación la frontera entre los dos derechos es orgánica $c$ institucional. El nuevo derecho es el derecho de la sociedad internacional organizada en institución internacional.

Tal no es la opinión de Alejandro Alvarez. Si lcs he dado cierta opinión personal es precisamente porque creo que ello 
nos permitirá apreciar mejor la visión que tiene Alvarez del nuevo derecho.

Posición de Alvarez frente al nuevo derecho. Para él, si bien el derecho de interdependencia social se encuentra evidentemente más acondicionado en el ámbito de una organización internacional, favorccido en su toma de conciencia, en su formulación y en su ejccución, existe sin embargo de antemano en la socicdad internacional todavía no institucionalizada (10). Para Alvarez el nuevo derecho existe en las dos sociedades.

Se podrá pensar quizás que este debate no tienc hoy dia gran interés por el hecho de ser 82, de los 100 Estados existentes, miembros de las Naciones Unidas; podrá existir la tentación de concluir que, ante un tan gran número de Estados miembros de las Naciones Unidas, el antiguto derecho interestatal sea afectado o no porque el nuevo derecho no concierne sino a muy pocos; podría pensarse que no concierne sino a aquellos pocos Estados que todavía no son miembros de las Naciones Unidas. Pero esta sería una apreciación errónea, porque si bien el derecho de la organización internacional es indudablemente un derecho nuevo, no es todo el derecho nuevo. El derecho de las Naciones Unidas, que es la institución internacional más amplia, no cubre todos los campos del derecho internacional; la Carta no es un código del derecho internacional público; la Carta define los objetivos de las Naciones Unidas y organiza el funcionamiento de esta institución, pero no es el código de todo el derecho internacional. Cuando un Estado ingresa a la Organización continúa, en todo lo que no está regulado por la Carta, sometido al derecho internacional exterior a este instrumento. De esta manera incluso para los Estados miembros de las Naciones Unidas existe un margen considerable de derecho internacional no institucionalizado, que permanece al margen de la Organización. Si entre dos Es-

(10) Como to veremos mas adelante, Alvarez es un gran partidario de la organización internacional y siempre Iuchó por su desarrollo. 
tados miembros se plantea un problema de derecho marítimo no es en la Carta donde podrán encontrar una solución inmediata. Lo mismo ocurre con un problema de responsabilidad. $\mathrm{Y}$ podrian mencionarse numerosas otras hipótesis.

Entonces cabe precisamente preguntar si acaso este derccho internacional exterior a la organización es un derecho clásico o un derecho nuevo. Les he expresado que personalmente me inclino por considerarlo como un derccho en gran medida clásico, porque la frontera entre ambos derechos me parece de orden institucional.

Pcro para Alvarez el derecho internacional exterior a la organización es desde ya, también, un derecho internacional nuevo, pues el régimen de interdependencia social se ha establecido de una manera espontánea y por tanto exige que estos Estados no apliquen más las reglas de este derecho internacional como lo hacían en los siglos XVIII y XIX, dentro de la sola perspectiva de un derecho repartidor de la protección jurídica que amparaba los intereses subjetivos de los Estados. Pero, según nuestro autor, incluso para los problemas del derecho internacional que no encuentran una solución preparada en una institución intcrnacional o supranacional, hay ya necesidad de hacer intervenir la consideración de la interdependencia social para dar a estos derechos una finalidad superior a la simple satisfacción del interés egoísta de cada uno de los Estados.

Evidentemente se trata este de un punto de vista muy generoso y que algunos han calificado ciertas veces de idealista. En realidad, creo que esta oposición entre los dos puntos de vista que acabo de presentarles no es tan profunda como podrá pensarse. Y ello por ċos razones:

- La primera razón es la siguiente: Alvarez no ticne inconveniente en sostener quc la interdependencia es un hecho social innegable, incluso al margen de la organización internacional. Personalmente sostengo simplemente que los Estados con frecuencia se resisten por egoísmo a reconocer esta interdependencia y a aceptar todas las consecuencias en sus rela- 
ciones jurídicas. Sobre todo los nuevos Estados que han accedido hace poco a la independencia y que, por fuerza, se encuentran todavia sicológicamente cn un ambiente político difícil, se inclinan por una gran intransigencia.

Sin duda alguna que existen fenómenos de interdependencia social, pero todos los Estados no participan en todas las circunstancias y continúan guiados esencialmente por su propio interés.

- La segunda causa es que el ra\%onamiento que Alvarez hace es el razonamiento de un juez. No olvidemos que él tiene la carrera de un juez. Desea, pues, por medio de una jurisprudencia pretoriana, acelerar el reconocimiento por los Estados de las consecuencias de la interdependencia, inclusive al margen de la organización internacional. Creo a este respecto que tiene toda la razón. En efecto la jurisprudencia debe conducir a los sujctos de derecho a esta toma de conciencia que es indispensable. La jurisprudencia debe inducir a los Estados más allá todavía de la toma de conciencia, y desarrollar la organización internacional y especialmente la organización regional, de la cual ustedes saben que Alejandro Alvarez es el más ficl partidario.

Dicho de otro modo, su actitud es una actitud promotora. Entiende que como juez debe actuar sobre los Estados, cada vez que la ocasión se presenta, para ayudarles a considerar el estado de interdependencia social en el cual se encuentran efectivamente, desćenlo o no, lo que por cierto tiene que ayudar en definitiva a la organización intcrnacional misma, pues los Estados que han tomado conciencia de su interdependencia naturalmente se acercan al entendimiento organizado. Este es un movimiento que podemos observar en todas partes; recientemente lo hemos visto en los Estados del Medio Oriente, algunos de los cuales van más allá de la organización internacional puesto que han terminado en una fusión. Y lo vemos también en un movimiento que agrupa un número considerable de Estados, llamado el movimiento de Bandung, que a la hora actual tiende a organizarse y a darse una estruc- 
tura mínima. Finalmente corresponde recordar que es sobre todo la Europa de los seis la que atestigua, a este respecto, las más espectaculares realizaciones.

La actitud de Alvarez es naturalmente progresista puesto que propende a extender la organización internacional. El asigna la más grande importancia a esta organización pues sólo ella puede verdaderamente facilitar la transición del derecho clásico al derecho de interdependencia, teniendo en cuenta el hecho de que este último conlleva irremediablemente el declive del individualismo y de su corolario que es la soberanía del Estado.

\section{B. El declinar del individualismo estatal}

Sostuvo Alvarez en su opinión disidente en el asunto de la Anglo-Iranian en 1952 que, como consecuencia de la aparición de grandes factores desconocidos de antemano, el régimen tradicional $\mathbf{e}$ individualista de la soberanía absoluta de los Estados comienza a ceder paso a un nuevo régimen, que da nacimiento al derecho de interdependencia social. En estas condiciones el declinar del individualismo conlleva aquel del voluntarismo, de uno o de otro modo, de la soberanía. Dos problemas se plantean entonces: ¿Qué sucede con la noción de soberanía en el nuevo derecho internacional? ¿Y qué sucede con la noción de igualdad que siempre ha sido considerada como paralela y concomitante a la noción de soberanía?

1) ¿Debe ser suprimida la soberania del Estado? Ustedes saben que toda una doctrina del derecho de gentes reclama el fin de la soberanía. Y es evidente que la lógica está de su parte ¿Cómo admitir un derecho internacional, es decir un cuerpo de normas jurídicas al cual los sujetos de derecho que son los Estados deben someterse, si acaso estos Estados se consideran soberanos? En la definición estricta de soberanía encontramos esencialmente la noción de un poder supre- 
mo, sobre el cual no existe ninguna otra autoridad. El fin de la soberanía sería el fin del Estado, o por lo menos de la anarquia que ha reinado frecuentemente en las relaciones interestatales.

Siendo Alvarez el campeón del nuevo derecho quizás debiera aparentemente habcr sumado su voz a aquella de los autores que reclaman este fin de la soberanía. Sin embargo no lo ha hecho. Considero, por mi parte, que para ello hay por lo menos dos razones:

- Desde luego Alvarez es chileno, es un sudamericano. quienes tradicionalmente se encuentran apegados a la noción de la soberanía del Estado, puesto que se trata de Estados todavía jóvenes; durante el siglo XIX lucharon por el respeto de una sobcranía que entonces acababan de adquirir y en el Nuevo Munclo, particularmente en América Latina, la noción de democracia y la noción de soberanía del Estado se confunden en una sola y misma noción. Cualquiera que sea el régimen político en América Latina se dirá que es democrático si acaso no ha sido impuesto por el extranjero.

Dicho de otro modo, la democracia es una noción internacional más que nacional, confundiéndose con la independencia nacional. Es así como, sobre esta base, el Brasil tuvo un régimen imperial en el tiempo del emperador Pedro.

La libertad del individuo y la libertad del Estado son dos nociones que encuentran su confluencia, en el pensamiento político de América Latina, en Ia independencia nacional.

La tesis no puede ser más bella; sc explica por razones históricas. Ciertamente que todavía en la actualidad un hombre como Alvarez, latinoamericano, conserva sentimentalmente su apego por esta doctrina de la soberanía.

Veo en segundo lugar otra razón para esta fidelidad. Es el realismo de Alvarez.

Parece de suyo audaz reclamar el fin de la soberanía del Estado en un momento en que quizás jamás como hoy día se ha visto a los Estados más apegados a esta noción. Ciertamente, un determinado número de Estados, particularmente los 
europeos, han establecido entre ellos convenciones e instituciones que suponen de su parte importantes sacrificios a la soberanía; pero también hay un gran número de Estados cuya soberanía y cuya existencia misma son recientes y que, por lo tanto, son sumamente celosos; sería en consecuencia sumamente irreal, un pecado contra el realismo, querer sostener hoy día el fin de la soberanía.

No significa esto que Alvarez pretenda encerrarse en una impasse; y, permaneciendo fiel a la soberanía, impedir toda posibilidad de reinado del derecho. Es lo que demostraremos a continuación.

Si bien Alvarez permanece fiel a la noción de la soberanía, estima que ella se encuentra limitada por el derecho de interdependencia social. La razón fundamental para ello es que el Estado ya no se encuentra solo. "Encontramos hoy día -escribe él- numerosas obligaciones de los Estados, sin que encontremos al titular del derecho relativo a estas obligaciones". Este titular es la sociedad internacional.

De esta manera Alvarez reconoce:

a) Primacía del derecho internacional. Que el derecho internacional prima sobre el derecho nacional. Los actos cometidos por un Estado en violación de este derecho engendran su responsabiiidad. Proclama entonces el principio de la primacía del derecho internacional sobre el derecho interno.

Desde 1938, en su declaración de los derechos de los Estados, precisaba que el Estado es soberano y que la soberanía debe entenderse en el sentido de que es dueño en su territorio, que tiene el derecho de gobernarse por sí mismo, de legislar en cl interior de sus fronteras y de establecer libremente las relaciones con los demás Estados; pero agregaba (Art. 13 párrafo 2): "En el ejercicio de su facultad, el Estado siempre está sometido a las normas del derecho internacional". Particularmente estima que, en caso de conflicto de una ley interna y un tratado, los tribunales deben aplicar la regla internacional con preferencia de la ley nacional. 
En la actualidad estos principios tienden cada día más a ser reconocidos; lo fueron en la Constitución de la segunda república española y también lo han sido en el régimen francés, en el artículo 28 de la Constitución de 1946.

Sin embargo, si bien Alvarez se pliega a la idea de la superioridad del derecho internacional sobre el derecho interno, no hay que creer que por ello también sigue a los autores que defienden la regla de la jerarquía de las normas de una manera absoluta.

En efecto, esta jerarquía descle el punto de vista de Alvarez sólo existe en lo interno del derecho internacional, regional o mundial, pero solamente en las relaciones entre el derecho nacional y el derecho internacional, regional o mundial. Por el contrario, recordarán ustedes que en las relaciones entre el derecho regional y el derccho universal, entre la organización regional y la organización mundial, no hay subordinación de la una respecto de la otra sino una simple correlación. Su adhesión a la jerarquía de los ordenamientos jurídicos es entonces parcial o sólo vale para las relaciones del derecho interno con el derecho internacional.

Estando así limitada la sociedad por el derecho internacional ello significa restricciones en la jurisdicción doméstica.

b) La jurisdicción doméstica. Alvarez, en su opinión disidente del caso de las pesquerias del 18 de Diciembre de 1951, cuestionó un principio que durante largo tiempo fue considerado como uno de los más importantes del derecho internacional clásico: el principio de que el Estado tendría el derecho a hacer todo aquello que no está expresamente prohibido por el derecho.

Encontramos asi un problema célebre y difícil: el problema de las lagunas en el ordenamiento jurídico internacional. Cuando nos encontramos en presencia de una laguna del derecho, es decir, cuando este derecho no nos da ninguna regla escrita, ni ninguna regla consuetudinaria, ni un principio general, en otras palabras, cuando el derecho guarda silencio 
¿cómo debe apreciarse el comportamiento de los Estados en un sector que no ha sido regulado por el derecho? Frecuentemente se contesta esta pregunta sosteniendo que en caso de una laguna del derccho, debe decidirse que el derecho internacional no ha permanecido en silencio; que no hay pasivo juridico, que hay una regla jurídica de carácter permisivo que pudiera enunciarse así: todo aquello que no está prohibido está permitido. De esta manera, en caso de laguna del derccho, nos encontraríamos en presencia de una competencia discrecional del Estado, la cual no hay que confundir con la soberanía pues si bien permite al Estado actuar con entera libertad o no actuar -exactamente como un soberano-, por el hecho de tratarse sólo de una competencia ella es susceptible siempre de ser modificada por quien pueda reglamentar su ejercicio. Mientras ello no ocurra la competencia permanece enteramente discrecional y el Estado puede actuar válidamente como lo considere conveniente.

Es precisamente esta regla la que Alvarez cuestiona en Ia actualidad. Al respecto escribe: "Estc principio, exacto en otra época bajo el régimen de la soberanía absoluta, ya no lo es hoy día. La soberanía absoluta tuvo su tiempo; la soberanía de los Estados está de ahora en adelante limitada..., está limitada no solamente por los derechos de los Estados sino por diversos elementos $\mathrm{y}$, entre ellos, el interés general de la sociedad internacional y la prohibición del abuso del derecho". Esta es una observación justa pues el soberano que aspira a un poder tolal para ser verdaderamente soberano debería encontrarse solo.

¿Cuál es entonces el lugar del dominio reservado de los Estados en el nuevo derccho internacional? Alvarez examinó este problema y en su opinión disidente en el asunto de la Anglo-Iranian enunció cuáles eran, en el derecho clásico, las diversas materias que constituían el dominio reservado. Explica que, en el régimen individualista y de soberanía absoluta del Estado en el derecho clásico, los Estados tenían un dominio reservado sumamente amplio, en cuyo interior el derecho 
internacional no intervenia. Cita particularmente la posibilidad de cada Estado de establecer la organización política interna que estimara más adecuada sin tener que darle cuenta a nadie; el poder de dictar las leycs que juzgara necesarias, incluso si eran contrarias al derecho internacional; podía determinar libremente cuáles eran sus nacionales; podía con toda libertad señalar los derechos civiles de sus nacionales, podía disponer libremente de sus riquezas y no estaba afecto prácticamente a ningún tipo de responsabilidad.

Hoy día, por cl contrario, todas las materias que acabamos de indicar comienzan a internacionalizarse total o parcialmente. Se admite particularmente que el Estado que, en el ejercicio de sus derechos, causa un daño debe indemnizar. Comienza igualmente a introducirse la noción del abuso del derecho, a la cual Nicolás Politis consagró un curso de la Academia cie La Haya el cual, si bien ya es antiguo, todavía conserva una extraorciliaria importancia.

Alvarez cita al respecto un ejemplo: "Si bien es cierto que cada Estado puede establecer la organización interna que le convenga, ćsta debe sin embargo permitirle cumplir con sus obligaciones internacionales; de lo contrario este Estado no puede ser admitido como miembro de las Naciones Unidas o puede ser excluido; y en todo caso si, como consecuencia de su defectuosa organización interna, causa un perjuicio a otro Estado, debe indemnizarlo". Es evidente que si un Estado incurre en denegación de justicia orgánica en el sentido de no haber otorgado a su servicio de justicia nacional una estructura suficientemente eficaz y que, por esta razón, causa perjuicios a extranjeros, éstos tendrán la posibilidad de demandar una reparación.

En el pensamiento de Alvarez, el dominio reservado parece presentarse en la actualidad en dos planos: por una parte, en la organización internacional donde conserva un valor certero, cuyo efecto es el de delimitar las zonas abiertas para la intervención de la organización y aquellas que se reservan para la acción exclusiva de los Estados (Art. 2 № 7 de la 
Carta, Art. 15 № 8 del Pacto) y, por otra parte, en el exterior de la organización: en este último caso cuando el Estado actúa, ya se encuentre ćl o no en un sector considerado como dependiendo de su competencia nacional, siempre permanece en el plano normativo sometido al derecho internacional.

La soberanía es una noción que algunos autores han abandonado totalmente y rechazado del vocabulario, reemplazándola por la noción de competencia. Alvarez permanece fiel a la antigua terminología de soberanía. $i$ Es esta una contradicción? Creo que para entender simultáneamente esta fidelidad terminológica y este rechazo de la noción, es necesario admitir que el vocablo soberanía encuentra dos acepciones: En primer lugar una acepción esencialmente política que se confunde con la noción de independencia. Decir que un Estado es soberano no significa, en esta primera acepción de la palabra, que rechace someterse al derecho internacional; es simplemente decir que este Estado no se encuentra situado bajo la dominación de otro Estado, significa que tiene su independencia y que puede de esta manera reivindicar efectivamente su calidad plena de Estado. Correspondiendo la soberanía a una noción política no podría rechazársele porque ella se confunde con la independencia nacional. Sin embargo, no pone en duda la sumisión del Estado al derecho. En cambio en el plano jurídico, en efecto, la soberanía es un vocablo que se conserva a título de recuerdo, pero que más valdría cambiar por el término competencia, que significa un poder circunscrito por el derecho.

Tal es, en realidad, la opinión de Alvarez puesto que sostenía que en ejercicio de sus facultades los Estados siempre se encuentran subordinados a las normas del derecho internacional.

Pero, entonces, si acaso los Estados se encuentran sometidos al derecho internacional, si acaso su soberanía no excluye esta sumisión, ¿qué ocurre con el principio de la igualdad que siempre fue considerada como el corolario de la soberanía? 
2) El principio de la igualdad de los Estados. El principio de la igualdad de los Estados ha sido criticado en la organización internacional. Se ha hecho valer que el régimen de igualdad funcional, sobre el cual descansó la Sociedad de las Naciones, era particularmente cuestionable. Se ha observado que un Estado pequeño, sin ninguna responsabilidad internacional, podría bloquear el funcionamiento de Ja Sociedad y obligarla a cerrar al rechazar su voto para el presupuesto, puesto que la igualdad funcional equivale a la regla de la unanimidad de los Estados.

De alli la idea de acondicionar, en el interior de las organizaciones internacionales, una distribución de los Estados según sus responsabilidades en la vida internacional; de plantear la regla de la igualdad de los Estados ante el derecho pero de atribuirle posibilidades de acción diferente en la organización según la importancia de su responsabilidad respectiva. Es el sistema de la ponderación.

Numerosos autores han estudiado este problema, particularmente el americano Sohn, quien ha escrito numerosos estudios sobre el tema y especialmente un artículo en el "American Journal" (volumen 40, 1946, págs. 71-99).

Alvarez en su declaración de los grandes principios señala que los Estados son iguales ante el derecho. Esta precisión es muy inportante pues es evidente que no se puede ser verdaderamente iguales sino ante una cosa o ante un valor trascendente. Son iguales, pero ante el derecho. Cada uno tiene la misma posibilidad de beneficiarse en el derecho internacional y de estar sometido a sus obligaciones de una manera equivalente.

Pero agrega (Art. 16, párrafo 2): "La igualdad jurídica no confiere necesariamente una igual cooperación en la constitución y en el funcionamiento de los órganos creados para la gestión de los intereses de la comunidad internacional".

Cuando escribía estas ideas en su declaración de 1931, se apartaba del plano sobre el cual descansaba tanto la Sociedad de las Naciones como el sistema interamericano. En parte es 
en este sentido que las organizaciones han evolucionado en razón del lugar cada día más importante que se da a la regla del voto mayoritario que se impone sobre la minoría (Alvarez siempre fue partidario de introducir el voto mayoritario). Por otra parte, esta idea encontró otra aplicación en la Organización de las Naciones Unidas, la cual descansa sobre un sistema directorial y privilegiado puesto que el Consejo de Seguridad se cncuentra en manos de los cinco grandes. Se estimó que la responsabilidad de estos Estados debía conllevar el reconocimiento en su beneficio de una situación privilegiada en el seno del Consejo (11).

Sin embargo, para Alvarez, si bien los Estados se encuentran beneficiados con un lugar preferencial en la organización, en razón de su importancia histórica, es menester destacar que no sc trata de un derccho subjetivo cl que les ha sido reconocido; no es una ventaja personal, es por el contrario una equivalencia de la responsabilidad y de las funciones que les es atribuida. De ahi que los miembros permanentes del Consejo de Seguridad - si continuamos razonando sobre la base de este ejemplo- participan en el funcionamiento del órgano no solamente en nombre propio sino también en nombre de los demás Estados de la organización. No ejercen un derecho subjetivo, sino una función social.

Es menester reconocer que Alvarez explicó este fenómeno a propósito de un problema diferente al de los poderes del Consejo de Seguridad; pero es fácil de demostrar que su razonamiento no es menos válido en este último caso. Presentó sus ideas a propósito del asunto de Africa Sud Occidental que la Corte Internacional de Justicia conoció en 1950. La Corte fue solicitada de emitir una opinión consultiva sobre

(11) Véase Drago "La Ponderación en las organizaciones internacionales". Annuairc Français de Droit International, 1956, págs. 529-547. Véase también nuestro artículo sobre "La Organización Internacional v la Expresión de la Vojuntad General". Revue Génćrale de Droit International 1957, Na 4. 
el estatuto internacional de Africa Sud Occidental. Recordarán ustedes que la Unión Sudafricana sostuvo que este territorio Ie pertenecía no obstante que, en el régimen de la Sociedad de Naciones, le había sido entregado bajo mandato. La Corte estimó que el mandato continuaba a pesar de la sustitución de la Sociedad de Naciones por las Naciones Unidas, puesto que la Unión Sudafricana había rechazado el sistema de fideicomisos. Alvarez explica lo que es el mandato. "El mandato es una misión sagrada de civilización. El acuerdo que ha sido creado no constituye un encargo o un contrato que deriva de cualquicr otra institución similar tanto nacional como internacional; el mandato ordinario es un contrato que sobre todo beneficia al mandante y está regido por los preceptos del derecho civil en tanto que la misión de que ahora se trata es una responsabilidad, ciertamente honorifica, pero desinteresada y en beneficio de determinadas poblaciones; es una función de carácter internacional que debe ser reglamentada por los principios conforme a su naturaleza. No pueden entonces aplicárseles, ni siquiera por analogia, los preceptos que rigen el mandato del derecho nacional...".

El mandato es una función social y no una ventaja que se reconoce a un Estado sobre un territorio y en perjuicio de una población; de la misma manera las diversas funciones que en una organización se confían a los Estados, no constituyen derechos privados, ventajas, sino misiones para las cuales son sometidas al control de los órganos de la organización. Esta fue una tesis defendida por De Visscher en la época de la Sociedad de las Naciones y que fue retomada en un estudio de Henri Rollin en los estudios en honor de Georges Scelle, aparecido en 1949.

Sin duda que de todos modos puede parecer chocante que tales privilegios sean reconocidos a los Estados, incluso a título de funciones. Pero ello es así porque precisamente $-\mathrm{y}$ aquí encontramos nuevamente el realismo de nuestro autor- no hay otro medio viable para realizarlo, pues hoy día las cuestiones políticas y las cuestiones jurídicas se entremez- 
clan muy estrechamente. Tal es la segunda consecuencia fundamental del derecho de interdependencia social.

\section{Derecho y Politica}

Si el derecho internacional está actualmente cada vez más penetrado por la política es porque la opinión pública juega en las relaciones internacionales un rol considerable, allí donde antes sólo intervenía la acción de los diplomáticos.

"El nuevo derecho internacional -escribe Alvarez- no es exclusivamente jurídico; también tiene un aspecto político, económico, social, sicológico, y de este hecho, la distinción entre lo juridico y lo político se encuentra hoy día profundamente alterada".

La idea de que el derecho internacional no es más exclusivamente jurídico es un planteamiento singular; ello significa que no se reduce a delimitar los derechos de los Estados, sino a armonizarlos tomando en consideración el interés general. También significa que el Estado se ve obligado a dar las cxplicaciones de sus actos.

En una de sus opiniones individuales Alvarez escribe que, por ejemplo, un Estado que delimite la extensión de su mar territorial -acto que ha sido considerado tradicionalmente como de su competencia discrecional- debe dar los motivos de esta delimitación personal, con el objeto precisamente de permitir una confrontación eventual y ulterior entre estos motivos y el interés general, confrontamiento que deberá ser hecho por las organizaciones internacionales a las cuales eventualmente se recurre. El derecho clásico por el contrario obligaba al intérprete a seguir fielmente el texto. Escribe: "Si uno se cine estrictamente al sentido literal del texto de derecho internacional que provoca una dificultad, se está inspirando en los postulados, axiomas y preceptos tradicionales del derecho en general, del derecho romano, especialmente del derecho 
natural, salvo en los países anglosajones donde se toma en consideración sobre todo los precedentes diplomáticos así como los postulados, axiomas o preceptos del derecho internacional clásico". Todos estos elementos no solamente no permiten obtener las consecuencias inmediatas y naturales que derivan, sino que además llevan a deducciones de una lógica que raya en los extremos; toda una técnica jurídica se emplea con este objetivo; de allí que frecuentemente se logren soluciones no razonables o inaceptables para la opinión pública. Este es el fracaso del derecho internacional clásico. El nuevo derecho internacional debe tomar en cuenta todos los aspectos políticos de los problemas, pues de lo contrario se realizará un simulacro de aplicar el derecho y nadie en realidad querrá someterse, razón por la cual el derccho caerá en desuso.

Alvarez destacó admirablemente este problema en sus planteamientos acerca de la opinión consultiva del 28 de Mayo de 1948. La Asamblea General de las Naciones Unidas consultó a la Corte acerca del punto de saber si es permitido subordinar su voto de admisión de un Estado en las Naciones Unidas, habiéndose reunido todas las condiciones jurídicas, a la condición suplementaria de que otros Estados sean admitidos al mismo tiempo.

Dicho de otro modo, ¿puede negociarse la admisión de los miembros de las Naciones Unidas?

Alvarez ve en esta solicitud de opinión consultiva la prueba de que la política interviene ahora en el derecho internacional, puesto que no se contenta con una respuesta que podría inspirarse en un estricto juridicismo; el derecho internacional comprende elementos políticos, puesto que la Asamblea ha creído su deber consultar a la Corte de La Haya preguntándole si acaso podía llevar a cabo compromisos políticos a propósito de la admisión de Estados; si ella hubiere deseado adoptar una actitud estrictamente jurídica, le habría bastado constatar que la Carta prevé un determinado número de condiciones de derecho, faltando las cuales los Estados no pueden ser admitidos, y no habría lJevado más lejos su pregunta 
Alvarez destaca que la cuestión planteada es doble, a la vez juridica y política. Lo jurídico prevalece, no tanto porque se trate de una interpretación de la Carta, sino más bien porque se trata de determinar el derecho que tienen los Estados para ser miembros de las Naciones Unidas si reúnen las condiciones cxigidas nombradas por el estatuto (Art. 4). Pero el asunto es al mismo tiempo político, puesto que son los Estados que forman parte del Consejo de Seguridad y de la Asamblea General los que aprecian si estas condiciones se han reunido.

Dicho de otro modo, este examen que en sí mismo puede ser asimilado a un examen no solamente jurídico sino todavia de alcance jurisdiccional, es confiado a órganos esencialmente políticos, el Consejo de Seguridad y la Asamblea General. En cstas condiciones los órganos politicos no adoptarán sus decisiones recurriendo únicamente a un criterio jurídico; también recurrirán a criterios políticos.

Antiguamente lo político era considerado como enemigo del derecho; hoy día conocemos la movilidad de las situaciones jurídico-políticas en la colectividad internacional; ¿signifjca esto que el derccho se va a diluir en la política? Ello se traduciría en el término del derecho internacional. De esta manera nos encontramos en medio de dos polos: Si no se desea tomar en cuenta la política y la opinión pública, se corre el riesgo de invocar reglas abstractas que nadie respetará. Y por otra parte, si deseamos cxagerar la importancia de lo político, nos encontraremos en un evolucionismo constante, se rechazará toda estabilidad y, finalmente, el derecho mismo no existirá más, pues este supone la seguridad de las relaciones jurídicas.

¿Cómo puede lograrse una conciliación de estas dos necesidades? Esencialmente por medio de la organización internacional. Ciertamente el orden interestatal no ofrece soluciones al confrontamiento de políticas en combate desordenado. La organización internacional, en cambio, tiene el mérito de ofrecer un marco para este enfrentamiento. Ella descansa en una carta básica que en sí misma está dotada de una cierta 
estabilidad, observándose por ejemplo que la Carta de las Naciones Unidas todavía no ha sido modificada. Esta Carta define los objetivos de las instituciones. Estos objetivos definen una especic de superpolitica que deben guiar a las políticas nacionales, o al menos permitir apreciarlas con referencia a sus normas.

La organización internacional presenta, en fin, la posibilidad de conciliar lo político y lo jurídico.

Creo por mi parte que la noción de lo político en derecho internacional puede al menos revestir dos significados.

- En un primer sentido lo político puede apreciarse en relación al normativismo. Se dirá entonces que lo político cuestiona el derecho existente y las normas en vigor pretendiendo su obsolescencia y tendiendo a reclamar su revisión. La organización internacional puede, en efecto, prever una revisión relativamente fluida del derecho internacional. Puede recordarse particularmente el artículo 19 del Pacto de la Sociedad de las Naciones que procuraba poner al día - si se me permite esta expresión- los tratados internacionales. La técnica era insuficiente; la Carta de las Naciones Unidas la ha retomado de manera muy imperfecta, pero de todos modos es en la organización internacional que el cambio pacífico tiene la mejor posibilidad de poder establecerse de la manera menos perjudicial (12).

(I2) Lo anterior no sigtifica de ningún modo que la organización debe necesariamente ser muy integrada o estar dotada de poderes stupraestatales. Por el contrario sólo una organización sie coordinación puede jugar un cierto rol al establecer wn marco permanente para los encuentros entre Estados que no comparten sino pocos sentimientos de su sotidaridad y que descanser sobre ideologías contrarias. Todo sistema de subordinación que resulte de uns estructura de poderes determinantes sería rechazado por el uno o por el otro. Tal es particularmente el caso de las relaciones entre los Estados Unidos y Rusia; la coexistencia pacífica entre estos dos pafses no podria en la actualidad ser impuesta por una institución suproestatal por la simple razón de que ni una ni otra aceptaría permanecer en una organización de este tipo. En un futuro cercano los progresos de la organización internacional mundial no pueden ser sino lentus. Lus acuerdos regionales concer. tados entre Estados que se encuentran ligados por una solidaridad más firme y mas conscientc, evolucionan con moyor facilidad hacia folmas integradas. 
-En un segundo sentido lo político no solamente cuestiona el normativismo sino también la acción gubernamental, es decir, la orientación de los órganos de una institución internacional. Existe una política de tal o cual organización internacional, cuyos órganos realizarán opciones de naturaleza política. A este respecto, la organización tiene la ventaja de mantener contactos internacionales; incluso en los peores momentos de la guerra fría, los rusos y americanos en circunstancias que no se encontraban en ninguna parte se reunían en los órganos de las Naciones Unidas.

Evidentemente esa es la definición de una política de la organización internacional donde puede medirse con mayor intensidad la importancia de la interdependencia social entre los miembros. Mientras más vasta sea una organización más difícil es encontrar una política común. Por el contrario, en una organización internacional de carácter regional, la definición de los objetivos políticos es más fácil, puesto que se encuentra en presencia de Estados y de pueblos que se acercan a mentalidades comunes, reacciones y necesidades similares.

Pero ya se trate de una organización vasta o restringida, es menester tencr muy presente que la política que la inspira, y que no deja de dominarla, no puede verdaderamente satisfacer las necesidades de la interdependencia social sino cuando se inspira en la justicia social.

\section{La justicia social internacional}

Para Alvarez el derecho de interdependencia social desemboca necesariamente en la justicia social internacional.

El movimiento hacia la justicia social es antiguo, pero prácticamente en forma exclusiva se desarrolló en el interior de los Estados. Como lo recuerda Alvarez, la concepción del derecho interno ha pasado por dos fases: 
- La fase de un derecho estrictamente jurídico e individualista que se proponía delimitar los derechos de los individuos y de los Estados, según la noción de una justicia absoluta más o menos abstracta. A mediados del siglo XIX, como consecuencia de la aparición de diversos fenómenos y particularmente del industrialismo y del proletariado, una nueva concepción del derecho se hizo presente: aquella del derecho social. Se refería sobre todo a tomar en consideración el interés de la clase obrera la cual, precisamente, era la víctima de esta justicia abstracta que no satisfacía sino a una parte de la sociedad interna y dejaba a la clase obrera al margen de esta satisfacción. Conocemos toda esta evolución que llegó hasta una legislación social y a una seguridad social que hoy día tiene una considerable importancia en las vidas nacionales.

El derecho internacional sufrió la misma evolución. Ciertamente, existen instituciones internacionales sociales, pero el derecho internacional social debe, para Alvarez, desembocar en una justicia social efectiva. No solamente debe dar lugar a organizaciones de investigación, estudios o información, por importante que ésta sea, sino también a estructuras dotadas de poderes susceptibles de permitirles actuar por si misma en el plano social internacional. No olvidemos que el problema internacional es un problema social planteado internacionalmente.

Es por esta razón que Alvarez estima que el nuevo derecho internacional tiene, ante todo, una finalidad social. El rechaza ver en este fenómeno una simpie abstracción, una especulación doctrinal, como a veces se ha pretendido; estima que este objetivo ya es una realidad del derecho positivo, no solamente porque encuentra sus razones en la conciencia juridica internacional, sino también porque tiene una expresión formal en el preámbuio de la Carta de las Naciones Unjdas -en los capítulos $4,5,9,10,11$ y 12 particularmente-, en las instituciones especializadas, en las resoluciones de las Asambleas - tal como las de la Asamblea General de las Naciones Unidas o de las Conferencias Panamericanas-, textos 
todos que tienden a incorporar en el derecho de gentes, sea continental o mundial, grandes nuevas ideas morales, políticas $o$ sociales.

¿Cómo pueden entonces realizarse estas finalidades? Esencialmente por el servicio público internacional. La asistencia técnica a los países subdesarrollados puede ganar mucho si es despolitizada y confiada a una agencia internacional, más que permanecer abandonada a los confrontamientos de imperialismo. Entramos así en un problema de medio, y ya no más de fines.

\section{Sección III}

\section{LOS MEDIOS DE EXPRESION Y DE ACCION \\ DEL NUEVO DERECHO INTERNACIONAL}

Al igual que la sociedad internacional fue modificada en sus dimensiones y en su naturaleza, debía, según ustedes recordarán, sufrir profundos trastornos en sus medios de expresión y de acción. El derecho internacional sigue paralelamente el mismo movimiento. Los medios de alcanzar las nuevas finalidades que le impone el principio de la interdependencia social son principalmentc tres:

-Las declaraciones.

-La organización internacional.

- La jurisprudencia.

A cada uno de estos medios Alvarez asigna un rol original.

1. Las declaraciones de los grandes principios

Alvarez comenzó siendo un apóstol de la codificación. En su juventud fue el teórico del hemisferio occidental. Al hacerlo permanecía fiel a la tradición panamericana, tradición que se remonta a la Conferencia de Panamá en 1826 convocada por Bolívar que ya había previsto una codificación del derecho americano. 
Desde la Conferencia de México en 1901 los Estados del Nuevo Mundo habian decidido la codificación del derecho internacional privado. En 1928 fue adoptado el Código de Bustamante de derecho internacional privado. Fue este el esfuerzo más importante que se ha hecho en el mundo en este campo; agrupando 473 artículos que sientan las bases para la solución de los conflictos de leyes en materia civil, penal y procesal en el Nuevo Mundo.

En la V Conferencia Panamericana de Santiago se quiso codificar $\mathrm{cl}$ derecho internacional público tomando como base los trabajos de Alvarez, quien había publicado "El Continente Americano y la Codificación del Derecho" que ciertamente es una de sus obras más importantes.

En la actualidad Alvarez ha evolucionado. La evolución del derccho le ha parecido tan rápida que se encuentra menos apegado que antes a la codificación. Teme que la codificación, que es una obra precisa y de derecho estricto, pueda fijar excesivamente el ordenamiento jurídico. Más que esta reglamentación rigurosa y rápida es partidario hoy día de las declaraciones de los grandes principios, que le parecen permitir el funcionamiento de un método singularmente más flexible. Procura particularmente una declaración de los grandes principios y, a este respecto, es menester observar que pueden existir dos métodos diferentes para abordar el problema: la codificación por medio de Convenciones que pucde frecuentemente ser sólo un reconocimiento de los derechos existentes o, por el contrario, declaraciones que pueden ser la expresión de nuevas reglas y que sobre todo pueden ser formuladas de una manera suficientemente amplia como para guardar una flexibilidad y márgenes adecuados para la evolución.

Más que reglamentaciones son los principios que deben ser establecidos. Y también a este respecto debernos destacar el realismo de nuestro autor. En la actualidad se desarrolla una conferencia de codificación del derecho del mar en Ginebra y es menester convenir que hay muy pocas razones para mostrarse optinista sobre su futuro. Precisamente porque la 
codificación, con todas las exigencias de precisión y los riesgos de fijezas y de parálisis que provocan en el ordenamiento jurídico, no puede ser fácilmente lograda sobre todo al nivel mundial.

La técnica de la declaración es por el contrario mucho más realista. Con mucho más facilidad se puede lograr acuerdos acerca de los principios y, a pesar de que se puede tratar de principios generales, ellos no son inútiles. La jurisprudencia internacional tendrá siempre la posibilidad de referirse a cllos y de encontrar criterios suficientes, en circunstancias que las ambiciosas codificaciones que no terminan jamás dejan al juez internacional en presencia de un derecho que, con frecuencia, nada le aporta y que cae luego en obsolescencia.

Por esta razón la técnica de la declaración, de la cual Alvarez es el gran promotor, permitiría en un mundo que busca su expresión sentar al menos algunas grandes normas susceptibles de guiar a jueces y a los gobernantes, como grandes luces.

Habría sido paradojal que Alvare\% continuara exigiendo una codificación en circunstancias que insiste al mismo tiempo sobre los trastornos de la colectividad internacional y del derecho que la rige.

La declaración se contenta con enunciar los grandes principios directores que pueden condicionar la actitud de los Estados y orientarlos en una cierta dirección social, permitiéndoles al mismo tiempo una suficiente libertad como para que la declaración tenga oportunidad de ser aplicada. Más vale un sistema como éste, que a primera vista puede parecer menos ambicioso y menos coherente que una codificación detallada, pero que tiene por lo menos el mérito de adaptarse a los trastornos de la vida. La eficacia de esta fórmula debe desde luego ser completada con el rol que ella le asigna a la organización internacional, en cuyo cuadro los Estados podrán con mayor facilidad respetar las normas de estas declaraciones y precisar sus alcances. 


\section{El rol de la Organización Internacional}

La organización internacional puede intervenir de una manera muy activa en los progresos del ordenamiento jurídico. Ello puede ocurrir de dos maneras:

\section{A. La agilidad operacional}

La organización internacional depura al derecho internacional de los excesos del voluntarismo. En vez de tratados bilaterales o multilaterales negociados en conferencias diplomáticas reunidas especialmente para ese efecto, la organización internacional permite el voto y el voto por mayoría -artículo 18 de la Carta de las Naciones Unidas para la Asamblea General- de resoluciones que estos órganos pueden adoptar en el interés general que la institución internacional tiene como objetivo.

A este respecto numcrosos autores confunden los tratados internacionales con las resoluciones que son adoptadas en las asambleas de las organizaciones internacionales permanentes. Este es un error. El tratado es verdaderamente un acuerdo de voluntades pues cmana directamente de las voluntades estatales. Por al contrario, la resolución de un órgano -como la Asamblea General de las Naciones Unidas- es un acto jurídico que emana del órgano mismo, de la institución. Esta tiene una existencia propia que descansa en la Carta que sirve de base a la organización y sus resoluciones, decisiones o recomendaciones, cualquiera que sea su grado de eficacia jurídica, tiene cada una el valor de un acto del órgano y no de los Estados.

Es este rasgo el que distingue la elaboración de los tratados en conferencias diplomáticas, que no son órganos ni instituciones, de la elaboración de las medidas adoptadas en las asambleas permanentes instituidas, sobre todo cuando éstos son adoptados sobre la base de un voto de mayoría. Entonces, la decisión emana directamente del órgano, y si bien 
ciertamente los Estados participan, lo hacen de la misma manera como los partidos políticos participan en un parlamento en la elaboración de la ley. Cuando en un régimen parlamentario una ley es aprobada como consecuencia del acuerdo de dos o tres partidos políticos que han logrado constituir una mayoría en el seno de esta corporación, no puede analizarse esta ley como un contrato jurídico concluido entre los partidos que le han dado su aprobación; la ley no es la obra de los partidos, jurídicamente es la obra del órgano, del parlamento que la aprobó.

Este es exactamente el mismo fenómeno que vemos producirse en la organización internacional la cual responde a objetivos que han sido determinados en su carta de base; los Estados le han reconocido ciertas competencias que, de hoy en adelante, le pertenecen en propiedad.

La organización internacional, del hecho de su permanencia, del hecho de sus reuniones periódicas y regulares, tiene una existencia autónoma distinta del tratado que le sirve de base -pensemos en la Carta de Bogotá o en la Carta de San Francisco-; la organización tiene una vida personal que se desarrolla y estimula la evolución de la coyuntura internacional, y, por eso mismo, del derecho.

Por tanto es menester facilitar el funcionamiento de los órganos de la entidad internacional de manera de permitirle no permanecer fijos en una admiración beata de la carta fundamental con sus ojos vueltos hacia el pasado en el cual fue creada la organización, aunque sea recicnte, sino por el contrario hacia el futuro, pues ella ha sido constituida para enfrentar situaciones que no han podido todas ser previstas y evolucionar de esta manera juntas con las coyunturas.

\section{B. Rol de las Naciones Unidas}

Tal fue la posición adoptada por Alejandro Alvarez a propósito de la opinión consultiva del 11 de abril de 1949 de la 
Corte Internacional de Justicia de La Haya. Esta debía resolver el problema de saber si acaso la Asamblea General tenía la posibilidad de prescindir del veto del Consejo de Seguridad para decidir la admisión de nuevos miembros.

Recordarán ustedes que durante diez años numerosos Estados hicieron cola ante la puerta de las Naciones Unidas. Para ingresar en la Organización de las Naciones Unidas se requiere del voto de la Asamblea General previa recomendación del Consejo de Seguridad. La opción cntre el Este y el Oeste provocó un uso abusivo del derecho de veto, que bloqueó al nivel del Consejo de Seguridad las candidaturas que la Asamblea General no pudo por tanto examinar.

Por esa razón este último órgano preguntó a la Corte si podía, en caso de parálisis del Consejo de Seguridad sobre esta cuestión precisa de la admisión de nuevos miembros, examinar por sí mismo el problema de la admisión y eventualmente solucionarlo no obstante el veto dirigido por tal o cual Estado permanente del Consejo de Seguridad.

La Corte respondió negativamente. Pero en una opinión disidente Alvarez discrepó tajantemente del método de razonamiento de la Corte Internacional de Justicia. Estima él que la Carta es un medio y no un fin y que la Corte, así como ningún otro órgano de las Naciones Unidas, no debe permanecer estática ante cl instrumento. Estimó que Ia Asamblea podía investigar si acaso el veto era abusivo y, de serlo, debía proceder a la admisión de nuevos miembros a pesar del veto del Consejo.

En su opinión, este es un problema esencialmente jurídico planteado entre dos órganos políticos. Desarrolla entonces un examen que da un doble fundamento a su posición.

-En primer término un fundamento del nuevo derecho de interdependencia social que obliga a que la vida de la organización no sea interrumpida por el uso abusivo de un derecho, que no es un derecho subjetivo reconocido a los Estados sino que solamente constituye una función internaciona! investida cn ciertos Estados, como compensación por las res. 
ponsabilidades superiores que ellos pueden tener en la organización. textos:

$-Y$, en segundo lugar, un argumento derivado de los

Si se observa la terminología y el espíritu del artículo 27 párrafo $3^{\circ}$ de la Carta, resulta que el veto ha sido esencialmente previsto para las materias relativas al mantenimiento de la paz y de la seguridad internacional, como fue desde luego establecido en el curso de las negociaciones políticas de la Conferencia de Yalta. Igualmente si se observan las disposiciones de otros capítulos de la Carta-particularmente los capítulos 5, 6, 7 y 8 - puede apreciarse que el veto se refiere esencialmente a estos capítulos. Al margen de estas disposiciones las Nacioncs Unidas no debe ser quebrada por un uso abusivo del veto y Alejandro Alvarez introduce así en el derecho internacional y en la organización internacional esta noción del abuso del derecho, que descansa en el siguiente análisis: Los derechos tienen una función social; no son regalos que se obsequian a los agentes jurídicos; son misiones que le han sido impartidas; tienen una cierta finalidad y la desviación del derecho -la desviación de poder como se dice en derecho administrativo francés- no podría justificar una actitud jurídica válida.

Al sostener esto, Alvarez al mismo tiempo toma posición accrca de la interpretación de la Carta. Tiene una visión sumamente dinámica de este documento; y ello supone entonces que el juez internacional, encargado en la interpretación, será evidentemente el primer promotor de toda evolución. A él le corresponde acelerar este movimiento.

\section{El rol de la jurisprudencia}

La jurisprudencia internacional es para nuestro autor aquella de la Corte Internacional de La Haya, pues participó en sus trabajos durante diez largos años; naturalmente es sobre la base de esta experiencia que él razona. 
Existen diversas maneras de concebir el rol de un juez. Puede pensarse que el jucz desarrolla una constatación, lo que evidentemente es la definición más precisa de la función judicial desde un punto de vista técnico. El juez constata la conformidad o inconformidad de las actitudes juridicas con la ley objetiva. Tal es la definición clásica de la acción jurisdiccional.

Comprendo bien que haya múltiples teorías que se oponen sobre el punto de la naturalcza del acto jurisdiccional; algunas veces se hacen intervenir otros elementos, pero, en general, puede de todos modos retenerse este elemento fundamental que Duguit había observado: la constatación jurisdiccional. Esta constatación tiene una fuerza particular que deriva de la autoridad legal y de la autoridad de la cosa juzgada. El elemento de Ia constatación tiene la mayor importancia en el problema que examinamos. Si el juez constata cómo los individuos y otros sujetos de derecho se comportan frente a la norma objetiva, es bien evidente que no podría inclinarse por esta actitud en sí misma. Puede hacerlo en el derecho interno puesto que la norma jurídica siempre es relativamente más precisa; en la actualidad es frecuentemente demasiado precisa; y, finalmente, presenta múltiples contradicciones siendo cada vez más difícil de leer incluso para especialistas experimentados.

En derecho internacional este tipo de inconveniente no es demasiado frecuente, pero tenemos otros: la incertidumbre de la norma jurídica; incertidumbre que al mismo tiempo sc aprecia en su volumen y en su duración. Incluso suponiendo que se esté de acuerdo en el contenido de una norma en determinado momento de las relaciones internacionales, comenzamos a dudar sobre el punto de saber si ella está siempre en vigor o si acaso se acerca a la obsolescencia.

De esta manera el juez internacional tiene evidentemente una mayor libertad de acción y de movimiento que el juez interno. Según Alvarez debe aprovechar esta ventaja e inspirarse en las nuevas necesidades sociales, particularmente del 
derecho de interdependencia social; ¿no lo hace también el juez interno a pesar de la multiplicidad de textos? A veces el juez interno también desarrolla una jurisprudencia de la cual se ha dicho que es pretoriana. Conocemos, por ejemplo, en derecho francés, la jurisprudencia de la Corte de Casación sobre el artículo 1.384 del Código Civil en materia de daños causados por cosas inanimadas. Y bien podrian citarse otros ejemplos que demuestran que los jucces nacionales también saben inspirarse en las nuevas necesidades sociales.

Alvarez observa que, contrariamente a lo que pudiera pensarse, los jucces internacionales tienen una mayor pusilanimidad que los jueces internos para considerarse como dóciles servidores de la evolución. Los jueces internacionales tienen menos sentido de la historia que los jueces nacionales. ¿Por qué? Ello se debe a lo incierto y a lo precario de la jurisdicción internacional, a la cual sólo se recurre por el acuerdo de los Estados y permanece en el marco del respeto a su soberanía, pues debe tenerse en cuenta su gran susceptibilidad.

Desde el momento en que existe una Corte internacional de Justicia permanente ella debe subsanar estos errores. Ella debe inspirarse en las nuevas necesidades y en el derecho de interdependencia social que se ha formado de una manera espontánea, sin que los Estados hayan firmado ninguna convención, y que debe ser el principio básico de la política jurisprudencial.

\section{Politica jurisprudencial}

En estas condiciones, la Corte no es un simple juez que estatuye sobre la base del derecho existente; y aquí se aprecia bien la influencia americana, la influencia de la concepción anglosajona de la función judicial, respecto de la cual Alvarez es muy sensible. Coincide con toda una escuela que ve en el juez al creador de la regla jurídica, particularmente por la fuerza del precedente, pero sin que este precedente 
tenga un valor obligatorio eterno puesto que siempre estará dominado por la evolución de la coyuntura.

De esta manera se explica su opinión individual en el asunto del Canal de Corfú en 1949. Escribe: "Se cree generalmente que el rol de la Corte es solamente el de aplicar el derecho internacional existente sin preocuparse de saber si él corresponde o no a estas nuevas condiciones; y se piensa que si ella lo renueva se transformaría en un verdadero legislador. La Corte actual tiene ahora una nueva misión que no pertenecia, al menos formalmente, a la Corte precedente". Y Alvarez, que no descuida los argumentos de los textos, a pesar de su gusto por el evolucionismo, cita el articulo $13 \mathrm{de}$ la Carta de las Naciones Unidas que estimula a Ia Asamblea General para desarrollar progresivamente el derecho internacional y su codificación; deduce que la Carta misma está inspirada en la visión de una evolución de la juridicidad internacional, en la cual la Corte, que es el órgano judicial de las Naciones Unidas, debe evidentemente también inspirarse.

En fin, destaca igualmente que la Asamblea General en 1947, en su resolución 171, manifestó el deseo de que la Corte Internacional de Justicia desarrolle el derecho internacional, es decir, lo ponga al día. En estas condiciones, en la opinión de nuestro autor, la Corte tiene tres atribuciones:

-Primera atribución: Aquella de carácter antiguo que consiste en determinar el derecho existente, precisarlo o confirmarlo.

-Segunda atribución: Modificarlo. Esta modificación debe realizarse en conformidad a las condiciones actuales de la vida internacional, constatando la obsolescencia de los preceptos que están cn vigor sólo de una manera formal pero que no corresponden ya a las necesidades presentes.

-En fin, tercera atribución: La Corte no solamente tiene el rol de declarar la obsolescencia sino también de creación. Debe enunciar los nuevos preceptos que vengan a regir las nuevas materias. $Y$ si estas materias no existían constatar su creación y formular los principios que las rigen. 
Estas dos últimas atribuciones de la Corte deben influir en la evolución de la vida. Tal es el mensaje esencial de esta doctrina. Alvarez observa particularmente que al actuar la Corte de esta manera aplica un principio que es muy antiguo. En efecto, estima que estc comportamiento progresista y evolutivo de la Corte está perfectamente de acuerdo con la vieja norma de la "cláusula rebus sic stantibus", que habitualmente se aplicaba a los tratados pero que las jurisdicciones siempre se resistían a aplicar, debido a la prudencia de los jueces designados por compromisos interestatales. La idea que sirve de base a esta norma fundamental se encuentra en la sabiduría de las naciones; debe también animar el comportamiento creador de la Corte Internacional de Justicia.

Esta no deja, sin embargo, de ser difícil.

En tanto que la Corte, la Organización, la Carta de las Naciones Unidas como texto normativo, múltiples acuerdos y convenciones, reglas consuetudinarias en vías de formación, nuevos principios nacidos de la evolución de la colectividad internacional, constituyen todos un cuerpo de nuevas reglas de derecho internacional, es inevitable que se produzcan interferencias o compenetraciones entre el antiguo derecho y el nuevo derecho. 


\section{Capítulo II}

\section{LAS INTERFERENCIAS ENTRE EL ANTIGUO DERECHO Y EL NUEVO DERECHO}

Evidentemente estas interferencias son inevitables. En efecto, el nuevo derecho no ha suprimido el antiguo derecho. El derecho antiguo existe desde luego en el plano formal; si se trata del derecho escrito se le encuentra en las recopilaciones y no cxiste en derecho internacional la técnica del acto contrario que, por la aplicación más o menos fiel, del paralelismo de las formas, vendría a deshacer lo que ha sido hecho por ciertos Estados según ciertos procedimientos. Estas técnicas, bien conocidas en las legislaciones internas, faltan en el ordenamiento internacional de manera que en el plano formal el antiguo derecho siempre existe.

Pero permanece igualmente presente en las mentalidades de los jurisconsultos.

Alvarez parece estar imbuido por el deseo de vaciar el espíritu de los juristas de un cierto número de ideas o de principios adquiridos sobre la base del antiguo derecho.

Hemos visto que la opción de los dos derechos - del antiguo derecho y del nuevo derecho- puede ser concebida en torno a la noción de la institución. Se estima entonces, y tal es nuestra inclinación, que el nuevo derecho no encuentra verdaderamente aplicación sino en el marco de la organización internacional, mundial, regional o especializada. $\mathrm{X}$ por el contrario, en la sociedad clásica, que me atrevo a llamar la sociedad de relaciones, que desarrolla las suyas en un plano horizontal en el vasto ámbito interestatal, es siempre el derecho clásico, antiguo, el que se aplica. Ello ocurre porque los 
Estados natural o biológicamente se resisten a reconocer las evoluciones, aunque sean irrefutables, de la colectividad internacional. Sólo una organización internacional provista de un mínimo de competencia puedc obligarlos a adoptar actos de esta naturaleza.

De esta manera resulta que aun cuando exista ya al margen de la organización internacional una nueva juridicidad en potencia, de todos modos es sólo dentro de esta organización que el nuevo derecho puede ser consagrado eficazmente.

Alvarez estima que incluso al margen de la organización internacional, el nuevo derecho se encuentra ya en vigor. $Y$ su actitud se explica sobre todo por la profesión que ha ejercido de juez internacional, juez progresista que desea obligar a los Estados a tomar en cuenta lo más rápidamente posible las nuevas necesidades inspiradas por la interdependencia internacional. Su punto de vista, ubicado dentro de esta perspectiva jurisprudencial, es perfectamente justificado.

Cualquiera que sea la manera de apreciar esta coexistencia entre los dos derechos, sea la frontera entre ellos de carácter institucional o simplemente histórica como lo piensa nuestro autor, es evidente que hay campos de interferencias. Es menester, entonces, tratar de determinar el punto de compenetración y de contacto entre el derecho clásico y el nuevo derecho en un triple plano:

-El plano de los ámbitos del derecho internacional;

-El plano de los principios;

-El plano de los problemas.

\section{Sección I}

CONTACTOS EN LOS AMBITOS (ANTIGUO Y NUEVO)

Según Alvarez el derecho internacional presenta nuevos ámbitos. Estima que en el derecho internacional clásico existían cuatro ámbitos principales: 
-El ámbito terrestre (y todo lo que se refiere a la soberanía de los Estados puede ser estudiado en este marco);

-El ámbito fluvial;

—El ámbito marítimo;

-El ámbito aéreo.

En lo que respecta a las demás materias como agentes diplomáticos, inmigración, emigración, condición de los extranjeros y otros, todo podía ser encuadrado particularmente en el primer ámbito, en el ámbito terrestre. En efecto, por medio de un estudio del territorio puede cubrirse un cierto número de problemas que plantean las relaciones internacionales, pues todos encuentran su fundamento en un territorio.

En la actualidad Alvarez estima que es menester formular diversas clasificaciones respecto de los ámbitos del derecho internacional.

1. Reformulación de antiguas materias.

En primer lugar hay ámbitos antiguos, pero que en el derecho nuevo son considerados de una manera distinta.

A. El derecho de la guerra. Es desde luego el caso de la guerra. Todo lo que se refiere al derecho de la guerra en el sentido de las Convenciones de La Haya, le parece de una obsolescencia total. Parece difícil contradecirle después de lo que ha ocurrido durante las dos últimas guerras mundiales.

Estimo que todavía pueden considerarse algunas normas en vigor respecto de las guerras locales conducidas según los medios clásicos, pero desde el momento en que la guerra 
adquiere cjertas proporciones, todo este régimen, que había sido concebido en las dimensiones de un problema hoy día completamente sobrepasado, se derrumba lastimosamente.

En cambio, lo que Alvarez considera de gran importancia es el estudio de las tensiones internacionales, de las causas de las guerras, de los medios para evitarlas y para atenuarlas. De uno o de otro modo, postula todo un estudio que podrá ser considerado, no sin razón, como un estudio de carácter no jurídico, un estudio sicológico pero que le parece indispensable. La reglamentación de la guerra se derrumba por la muy simple razón de que está fundamentada sobre la base de ficciones o de realidades que desde hace mucho tiempo ya no se dan. Debe reconocerse que en la actualidad estos estudios de las causas de la tensión están a la orden del día en muchas instituciones científicas. Han sido muy desarrolladas en los Estados Unidos. El Instituto Solvey de Bélgica ha cmprendido investigaciones de este tipo sobre las causas y las manifestaciones de las tensiones. Igualmente el próximo congreso-que tendrá lugar en el mes de septiembre de 1958- de la Asociación internacional de Ciencias Políticas, ha puesto en su agenda esta importante materia. De esta manera si bien es exacto que las preocupaciones de Alvarez se inspiran más bien en una investigación de Ciencias Políticas que en una verdadera investigación de carácter jurídico, no es menos exacto que cn este momento tienen la mayor actualidad y el más grande interés para el futuro del derecho internacional.

Las actuales dimensiones de los conflictos cuestionan también el principio de la neutralidad. De ahora en adelante no se puede pensar en él en una guerra mundial. Cualquiera que sea el apego de la Confederación Helvética a este estatuto secular, si una bomba atómica estallara encima del territorio de alguno de los vecinos de la Confederación, ésta tendria todas las dificultades para protegerse, al menos respecto de la diseminación de materias radiactivas. Es evidente por tanto que la regla de la neutralidad ha entrado en obsolescencia, conservando sólo algún valor para los conflictos de carácter local. 
Pero si bien la neutralidad es impensable a partir del momento en que la guerra adquiere cierta temperatura, asistimos por el contrario, en la época actual, al renacimiento de una antigua institución que existía en las Civitas Christiana, dominada por el papado: la neutralización. Por ahora debe convenirse en que ella todavía no es aplicada, pero ocasionalmente se ha visto desde hace algún tiempo el surgimiento de proposiciones que se refieren no a la neutralidad en el sentido del derecho internacional sino a neutralizaciones, sobre todo en el plano atómico de ciertas regiones del mundo - pienso particularmente en la proposición del embajador George Kennan o en la proposición Rapaki-. ¿Qué ocurrirá con estas proposiciones? Nos limitamos simplemente a señalarlas como una búsqueda de suyo curiosa del renovamiento de la neutralización.

B. Las relaciones interestatales. De la misma manera las relaciones entre los Estados se rigen todavía por las reglas internacionales clásicas; los ámbitos de las relaciones interestatales no han cvolucionado marcadamente, pero Alvarez insiste a este respecto sobre las tres ciencias cuya creación rccordarán ustedes que él sugiere, las tres ciencias auxiliares del derecho internacional y que él considera pueden ayudar a aclarar las diversas condiciones dentro de las cuales se desenvuelven estas relaciones.

Estas ciencias permitirían clarificar y clasificar los factores sicológicos que juegan un rol tan determinante en estas relacioncs. Igual efecto se produciría en relación a los intereses, tanto materiales como inmateriales, y a los sentimientos que jucgan ahora un rol considerable en las relaciones internacionales, teniendo en cuenta la importancia de la opinión pública tantas veces recordada.

C. La utilidad pública. Después de haber considerado los ámbitos tradicionales, que estima deben ser abordados de 
acuerdo a nuevos métodos, postula igualmente el considerar en el mismo espiritu un estudio acerca del desarrollo de los ámbitos terrestres, fluvial, marítimo y aéreo; examinarlos en sus finalidades sociales que constituyen ámbitos del dominio público, estatales o internacionales, ligados a la utilidad pública internacional si se toma en cuenta esta interdependencia sobre la cual él tanto insiste. A este respecto se identifica con otra doctrina de Georges Scelle, quien ha demostrado que todo territorio nacional es por definición igualmente una parcela de territorio internacional y que el Estado, cualquiera que sea la amplitud de su competencia territorial, responde cn este territorio de ciertas obligaciones internacionales. Alvarez llegó a conclusiones idénticas en su declaración de 1932. En fin, en lo que respecta al mar, nos encontramos en presencia de un dominio público internacional, exactamente como aquel que se aplica a los ríos de interés internacional, que deben de ahora en adelante sustraerse a las aprehensiones soberanas de los Estados.

\section{Los nuevos ámbitos}

También existen campos que son enteramente nuevos. ¿Cuáles son cstos nuevos campos del derecho internacional a juicio de nuestro autor?

A) El dominio polar. En el plano del dominio territorial, se trata principalmente del dominio polar. El Artico se encuentra generalmente en una situación jurídica suficientemente estable; en cambio el régimen de la Antártida todavía no alcanza una estabilidad suficiente, accrca de lo cual me permito sugerirles el tratado de Charles Rousseau, donde esta materia de las regiones polares es expuesta de una manera 
muy clara y completa (13). Diversos estados de Europa y de América, la Rusia soviética, Francia - con la Tierra Adelaida--, los países de América Latina - particularmente Argentina y Chile, la patria de Alvarez-, han invocado reivindicaciones sobre el territorio antártico. No deseo tratar aquí este problema pero si agregar que Alvarez demuestra a este respecto que a pesar de sus largas estadias en Europa, en Francia, y particularmente en París, sigue siendo de todos modos un latinoamericano en el sentido de que se encuentra muy apegado a las tesis de que a los países americanos que sean más cercanos, y particularmente los países del sur del continente, se ies reconozca derechos particulares sobre la Antártida. Pero cualesquiera que sean estos deseos, inspirados en un patriotismo persistente, de todos modos abriga el deseo formulado en numerosas ocasiones de internacionalizar estas regiones en beneficio de todos los países del mundo y, a este respecto, apoyó una proposición que había sido hecha por los Estados Unidos en 1947 en cl sentido de internacionalizar el continente antártico.

B) El nuevo derecho del mar. Desde otro punto de vista, el dominio marítimo ha sido enteramente renovado.

Anteriormente, como ustedes saben, el mar era una vía de comunicación; hoy día más que eso es un tesoro. Ya hemos señalado esta transformación. Ahora es menester demostrar sus consecuencias. Cuando era esencialmente una vía de comunicación todo el derecho me parece haber sido concebido en función de ese movimiento. Si para ciertos tipos de pesca un barco debía detenerse, se trataba de una situación momentánea pues no podía establecerse en el mar. Todo el régimen jurídico del mar fue concebido dentro de este movimiento. Por esta razón la libertad de los mares se confundía con la libertad de navegación. Todo ello determinaba una pers-

(13) Véase Charles Rousseau, números $301 \cdot 305$. 
pectiva en que el mar era considerado "via de tránsito" y "vínculo entre los pueblos y los continentes" (14).

En el caso del mar considerado como tesoro se produce el fenómeno contrario, pues en numerosos casos, y particularmente los relativos a la explotación de las riquezas del suelo y del subsuelo marino, supone una utilización fija. Obviamente se produce entonces un enfrentamiento entre el régimen jurídico concebido exclusivamente en función del movimiento y un otro régimen jurídico en vias de formación, que supondrá apropiaciones de carácter privativo. Siempre se podrá reprochar a quienes reclaman csta apropiación de violar la libertad del mar, o, por el contrario, esforzarse de justificar estas apropiaciones rechazando el principio de la libertad de los mares por obsoleto; en realidad este debate está mal planteado; es un debate entre interlocutores que - si ustedes permiten la expresión- no se encuentran en la misma longitud de onda y no logran jamás establecer contactos; cada uno habla para si mismo y no escucha lo que dice el otro.

La libertad de los mares responde a la utilización tradicional, desde luego siempre muy importante, fundamentada en el movimiento. La otra tesis supone, en efecto, objetivos y medios diferentes. Por esta razón jamás se logrará, lo que puede apreciarse muy bien en la actualidad en la Conferencia de Ginebra sobre la codificación del derecho del mar, ponerse de acuerdo acerca de teorías que se inspiran en realidad en fenómenos profundamente opuestos.

Alvarez, por su parte, estima que en la actualidad el mar, desde un punto de vista jurídico, debe analizarse de acuerdo a cuatro etapas. Su visión personal es una visión estratificada.

-En primer término se encuentra la superficie, con sus tradicionales utilizaciones clásicas, siempre renovadas desde luego por las técnicas que frecuentemente ponen en peligro

(14) Las utilizaciunes de carácter privativo, como aquellas que derivan del régimen de pesquerius sedentarias, resultaban ser completamente excepcianales. 
el futuro de las especies y que exigen de nuevas legislaciones y reglamentaciones. líquida;

-En una segunda etapa se encuentra también la masa

- Luego, como tercera etapa, el fondo;

-Y por último como cuarta etapa, el subsuelo.

Es precisamente a propósito de cste régimen marítimo, y particularmente en lo relativo a la extensión del mar territorial, que el método propuesto por Alejandro Alvarez de declaraciones de grandes principios parece revelarse como más fecundo que el método de la codificación por vía de convención, que actualmente se ensaya en Ginebra.

$¿$ Por qué tratar a toda costa de fijar una medida que sirva de límite a la extensión del mar territorial, en circunstancia que cada Estado se encuentra a este respecto en diferentes situaciones geográficas, económicas y demográficas? $¿$ ¿Por qué hacerlo cuando se trata de situaciones marítimas enteramente diferentes? Algunos Estados tienen aguas adyacentes muy profundas, otros tienen aguas que no revisten un interés particular, algunos sc encuentran preocupados por las alternativas estratégicas en tanto que otros por el deseo de proporcionar una mayor alimentación a un pueblo insuficientemente nutrido. En estas condiciones probablemente jamás se logre acuerdo acerca de una medida determinada. Más val. dría contentarse con señalar, en una declaración, los grandes principios de la utilización funcional del dominio marítimo internacional. Habría que renunciar a determinar derechos absolutos, como ocurría en el antiguo derecho clásico. La expresión "mar territorial" evoca admirablemente una noción del antiguo derecho, con una idea de un territorio sumergido al cual no podía determinársele una frontera visible pues el medio líquido se oponía, pero que de todos modos derivaba de una noción del dominio romano, de apropiación territorial, como si se hubiera deseado trabajar el mar. Más valdría establecer los principios, que no reconocerian derechos subjetivos 
individuales a los Estados sobre el mar, pero que señalarían las reglas de una utilización funcional en el sentido de las necesidades impuestas por la interdependencia actualmente existente entre los Estados (15).

Más todavia, Alvarez estima que la alta mar ha dejado de ser "res nullius" o "res communis". Es necesario reglamentarla para un cierto número de materias $y$, particularmente, para prohibir ciertos ensayos, especialmente los ensayos atómicos.

C) El derecho interplanetario. En fin, otro dominio nuevo que nuestro autor considera extremadamente urgente de elaborar: cl derecho interplanetario. Ustedes saben que incluso en la Conferencia de Barcelona, que se celebró a fines de 1957, que era una conferencia técnica de sabios ajenos a lo juridico, los problemas jurídicos de todos modos fueron planteados porque no se puede discutir técnicamente las experiencias interplanetarias sin considerar los problemas del derecho. Cabe particularmente preguntarse si es o no necesario recurrir a una institución tan antigua como la ocupación, que ustedes saben que en el derecho internacional permite adquirir competencia territorial sobre territorios sin dueño, tal como en los viejos tiempos en que los marinos descubrian las islas desiertas y clavaban sus banderas para reivindicar su soberanía. Descansando sobre una manifestación de apropiación soberana tan débil y que, en el derecho internacional clásico, no producía efcctos si no se trataba de una ocupación efectiva, siendo ya una institución que se demuestra insuficiente para las regiones polares, que no permiten una presencia continua y efectiva, ¿podría ella aplicarse automática-

(15) Evidentemente que en el marco de estos principios sería menester, para que el sisterna pueda tener alguna posibiliclad de ser aceptado, de no cuestionar, en la medida de lo posible, los derechos adquiridos. De la misma manera sería necesario tuna cierta regionalización de los principios funcionales, con el fin de adap. tarlos a las particularidades de ciertas partes del mundo. 
mente a la luna? Esta es la razón por la cual nuestro autor insiste que desde ahora debe ensayarse de lograr un acuerdo entre los grandes Estados acerca de este problema.

D) El ámbito social. Otro campo enteramente nuevo es el dominio social internacional, el cual, junto con el derecho internacional económico, tiene hoy día una importancia considerable y no ha sido suficientemente estudiado, siendo un dominio tan inexplorado como el de las regiones interplanetarias.

E) El derecho de la organización internacional. Por último está también el caso del derecho de las organizaciones internacionales, refiriéndose por una parte a las relaciones entre organizaciones y, por otra parte, al régimen interior de estas organizaciones. En efecto, se trata de estudiar las organizaciones internacionales, no solamente en el plano estricto de su estructura como frecuentemente se hace, sino igualmente en el plano del régimen al cual su funcionamiento permite llegar. Esta es la oportunidad de recordarles la oposición clásica entre la constitución y el régimen, así como la transición que hay entre estas dos nociones; la constitución sólo establece las reglas escritas en tanto que el régimen es el fruto de toda una evolución que ha sufrido la constitución en su aplicación en la práctica. A este respecto, ¿cómo podría no tenerse en cuenta esta diferencia si se considera, por ejemplo, la evolución ocurrida en la Organización de las Naciones Unidas en diversas materias y particularmente en lo que respecta al rol del Consejo de Seguridad y de la Asamblea General en el mantenimiento de la paz y de la seguridad internacional?

Sabemos cómo la Resolución aprobada por la Asamblea General el 3 de Noviembre de 1950 ha desplazado el centro de gravedad de la Organización y, en el hecho, ha terminado confiando a la Asamblea un rol en materia de mantenimiento de la paz y de la seguridad internacional que, en la Carta, incumbia esencialmente al Consejo de Seguridad. 


\section{LAS RELACIONES EN EL PLANO DE LOS PRINCIPIOS}

Alvarez estima que existen:

- Principios antiguos que hay que abandonar porque están obsoletos.

- Principios antiguos que hay que reafirmar para darles más eficacia y prestigio.

- Principios antiguos que hay que renovar conforme a las nuevas condiciones de la vida internacional.

- Nuevos principios bien establecidos ya.

- Nuevos principios que hay que proclamar porque todavía no han sido reconocidos plena y totalmente.

1) Principios antiguos que hay que abandonar

Los principios antiguos que es necesario abandonar son particularmente aquellos relativos al régimen colonial, así como aquellos relativos a la reglamentación de la guerra y de la neutralidad.

2) Principios antiguos que hay que reafirmar

Algunos de ellos se refieren a las relaciones entre Estados. Entre estos principios antiguos que deben recibir una nueva consagración, porque todavia permanecen en plena vigencia, encontramos el respeto mutuo de la integridad territorial y de la independencia política de los Estados, y las consecuencias son la prohibición de la agresión - regla tradicional en el derecho interamericano- y la no intervención de los Es- 
tados en los asuntos internos o externos de otro Estado por cualquier motivo que sea (16).

Si bien la intervención de un Estado en los asuntos de otro permanece proscrita, hay en cambio un tipo de intervención que aparece como permitida: es la intervención colectiva de una organización internacional desarrollada conforme a las disposiciones de los pactos de la organización de defensa en el plano mundial, continental o regional. La intervención condenable es aquella que es desencadenada unilateralmente, en forma discrecional por un Estado, pues ella está marcada por el impcrialismo; pero la intervención de todos modos es indispensable en la vida internacional en la medida en que tiende al mantenimiento de la paz. Se trata simplemente de legalizarla y de constitucionalizarla, quitándosela a los Estados y confiriendo su monopolio a la organización internacional.

En fin, deriva igualmente de este principio que ningún Estado puede hacerse justicia por sí mismo - lo que conlleva cl fin del régimen clásico de la guerra como duelo, en la cual el Estado podria emprender una acción de fuerza para probar su derecho-. El derecho del siglo XIX todavía establecía la guerra como un medio de probar el derecho por la fuerza. Un medio tan nocivo debe ser excluido.

Por otra parte, desde el punto de vista de la evolución, de las relaciones interestatales, la cláusula rebus sic stantibus,

(16) Desde 1890, la Primera Conferencia Panamericana habfa decidido la supresiún del derecho de conquista territorial y el no reconocimiento de todas las adquisiciones hechas por la fuerza. La conferencia de La Habana en 1928 aprobó una resolución que consideró la guerra de agresión como un crimen. Esste texto iba todavia más jejos que el pacto Briand-Kellogg, que no llegó a calificár como crimen el re. curso a la fuerzá.

En lo que respecta al principio de la no intervención de un Estado en los asurios internos de otro Estado, st fuc explf́citemente formulado en el Art. 8 de la Convencion Sobre Derechos y Deberes de los Estados, aprobada en la VIr Conferencia realizada en Montevideo en 1933. Actualniente se encuentra consagrado en el Art. 15 de la Carta de Bogotá. La intervención proscrita se refiere también a la penetra. ción polfíca y a la presión cconómica. Esta prohibición está lejós de ser siempre respetada en las relociones entre Estados Ĺnidos y América Latina (Véase Jican Dupuy "Le Nouveau Panaméricanisme". Ediciones Pedone. 1956). 
por antigua que ella sea, debe ser desde luego mantenida porque precisamente ella es, entre todos los principios del derecho, el único que verdaderamente permite la evolución.

3) Principios antiguos que hay que renovar conforme a las nuevas condiciones de la vida internacional

En este caso se trata de principios que históricamente descansan en el régimen individualista del interestatismo y que deben hoy día ser adaptados para conformarse al régimen de interdependencia.

Esta es la razón por la cual nuestro autor, en sus declaraciones, no se contenta con proclamar los derechos de los Estados sino que igualmente enuncia sus deberes. Estos últimos se refieren principalmente a la mantención de una organiza. ción política y jurídica que permita a todos los residentes en el territorio del Estado el ejercicio de sus derechos y el gozo de las ventajas que los sentimientos de la justicia internacional imponen hoy día a todos los pueblos. Entre ellos también se cuenta el deber de ejecutar de buena fe las sentencias de los tribunales internacionales, participar en la creación, funcionamiento y desarrollo de los servicios públicos internacionales, cooperar en la obra internacional de mejoramiento de la salud y del nivel social de las masas, cooperar igualmente en el progreso intelectual, desarrollar los sentimientos de solidaridad internacional y otros, todas las cuales son obligaciones que a su juicio se imponen a los Estados y que eventualmente la organización internacional o la jurisprudencia podrían sancionar haciendo efectiva su responsabilidad.

\section{4) Nuevos principios bien establecidos}

Estos principios son particularmente aquellos que han encontrado recientemente su consagración en la Carta de las 
Naciones Unidas. Puede pensarse en el derecho de los pueblos a la autodeterminación, acerca de lo cual Alvarez estima que ha sido proclamado por el Art. 1\%, párrafo 2 de la Carta con un carácter demasiado general. En efecto, estima él que no es suficiente proclamar el derecho de los pueblos a la autodeterminación; es necesario todavía prever un procedimiento mínimo que reglamente el ejercicio de este derecho. Nos acercamos así a uno de los problemas más difíciles, similar al problema de la huelga en el derecho interno. Es sumamente complicado reglamentar el derecho de huelga, pues ello supone el uso de la fuerza que evoca, en las relaciones sociales, lo que es la guerra en las relaciones internacionales. El derecho de los pueblos a la autodeterminación es un principio que ha sido planteado como si tuviera ya, por su sola proclamación, la virtud de permitir a los pueblos que se acogen a él su gozo efectivo sin que les sea necesario el recurso a medios de fuerza. Sin embargo el recurrir a medios de fuerza es difícilmente evitable según lo revela frecuentemente la experiencia histórica. En la actualidad este derecho de los pueblos resulta afectado por haber sido proclamado sin una reglamentación juridicamente efectiva. Su reglamentación debía efectuarse de tal manera que permita tanto al Estado en contra del cual el derecho se reivindica como a la población que lo reclama, encontrar en el sistema jurídico los medios de ponerlo en práctica sin que los primeros tengan que sufrir demasiado - sería en el plano del amor propio nacional-y los segundos tengan que reclamar demasiado - sería en el plano del recurso a la fuerza.

Ciertamente que se trata éste de un principio desnudo, exactamente como ocurre con la proclamación del derecho de huelga en algunas constituciones nacionales, pero que será muy difícil el otorgarle una construcción juridica que, por otra parte, tampoco tenemos aquí el tiempo de elaborar.

En la opinión de Alvarez el principio de que la guerra es un crimen contra la humanidad también se encuentra bien determinado. El fue establecido por el pacto Kellogg hace ya 
30 años y bien sabemos que en el mundo americano lo fue con mayor anterioridad todavía.

Por la razón anterior Alvarez permanece muy apegado al establecimiento de un tribunal internacional, que a su juicio debía ser nombrado por la Asamblea de las Naciones Unidas, encargado de juzgar a los jefes responsables de actos de guerra, criminales o contrarios a los principios de la humanidad.

Otro principio bien establecido es la regla de la coexistencia pacífica entre regímenes políticos y económicos diferentes así como entre diferentes razas y religiones, que él mismo enunció en 1932 en su declaración sobre las bases fundamentales del derecho intcrnacional. Declaraba en su Art. 19: "La interdependencia de los Estados es la base de sus relaciones recíprocas; su ayuda mutua es la condición de su coexistencia pacífica y de su desarrollo material y moral"; esta expresión, que en la actualidad se encuentra muy de moda, fue utilizada por Alvarez hace ya mucho tiempo. De aquí deduce él el principio de la no discriminación racial y religiosa, así como la no discriminación entre nacionales y extranjeros.

5) Principios nuevos que todavía no se encuentran bien establecidos y que están en vias de formación

Estos otros principios debían ser materia de una declaración fundamental a la cual los Estados no podrian oponerse. El Art. 20 de la declaración de 1932 elaborada por nuestro autor dispone: "Ningún Estado tiene el derecho de oponerse, en nombre de su interés particular, a la reglamentación jurídica de una materia de interés común. Sin embargo, cuando ejerce derechos especiales por un cierto lapso de tiempo, deben ser tomados en cuenta en la reglamentación". Esta segunda reserva se inspira evidentemente en un realismo incontestable. 
De estos principios, tres son esenciales:

- En primer término la libertad de navegación en los estrechos y canales internacionales, la cual, si bien ha sido proclamada formalmente en convenciones, le parece a la luz de los recientes acontecimientos internacionales todavia insuficientemente reconocido.

- En seguida la libertad de navegación interplanetaria. No solamente existe a su juicio un dominio interplanetario sino además un principio que es incuestionable: la libertad de la navegación.

- En tercer lugar, en fin, se encuentra el derecho de todos los Estados a las materias primas; ello involucra la ayuda a los Estados que se encuentran en necesidad, que sería para ellos un derecho, y por consiguiente la obligación correlativa para los Estados que tienen excedentes de contemplar y organizar tal ayuda bajo la dirección de la Organización de las Naciones Unidas.

\section{Sección III}

\section{LOS CONTACTOS EN EL PLANO DE LOS PROBLEMAS}

Desde el momento en que coexisten el nuevo derecho internacional y el antiguo derecho, es evidente que es en el plano de los problemas donde se van a apreciar con mayor intensidad las dificultades de solución que este enfrentamiento de las antiguas reglas con las nuevas provoca.

No podemos examinar todos los aspectos y todos los problemas que son afectados por esta oposición y por estas fricciones. He escogido, sin embargo, dos problemas que me parecen fundamentales y que Alvarez cn sus opiniones individuales o disidentes tuvo frecuentemente la ocasión de considerar. Se trata del problema de los tratados y de aquel de la responsabilidad internacional. 


\section{Los tratados}

El derecho tradicional ve en los tratados una pieza maestra que le pertenece en propiedad. El tratado es por excelencia la institución del derecho de relaciones de la sociedad interestatal. Parecería entonces que el derecho de los tratados es el que menos puede ser contaminado por el nuevo derecho.

Alvarez piensa, por el contrario, que los tratados mismos derivan hoy de un régimen que en gran medida se encuentra modificado por los imperativos de este derecho. Ello puede apreciarse desde el punto de vista de la naturaleza de los tratados, de su interpretación y de su extinción.

A) La naturaleza de los tratados. En lo que respecta a la naturaleza de los tratados, Aivarez elabora una clasificación muy personal y que expone en su opinión disidente a propósito de la Opinión Consultiva del 28 de Mayo de 1951 en el asunto de las reservas a la Convención sobre prevención y represión del crimen de genocidio.

Explica que en la actualidad los tratados multilaterales pueden dividirse en cuatro categorías:

- Primera categoría: Las convenciones que tienen por propósito desarrollar la organización internacional, mundial o continental.

- En segundo lugar, aquellas que tienen por objetivo establecer un estatuto territorial de determinados Estados. Estas convenciones han existido en Europa desde comienzos del siglo XIX donde constituyeron lo que se ha llamado el derecho público europeo.

- En tercer lugar, las convenciones que tienen por objeto establecer nuevos preceptos del derecho de gentes.

- Y, en fin, en cuarto lugar, las convenciones que se proponen reglamentar materias de interés social o humanitario, tendiendo a mejorar la condición de los individuos.

Esta clasificación tiene por criterio central la finalidad del tratado. Estima que estas cuatro categorias de convencio- 
nes presentan características que las diferencian protundamente de las convenciones multilaterales ordinarias. Tienen desde luego un carácter universal. En cierta medida son verdaderas constituciones de la sociedad internacional establecidas en beneficio del interés general y no del interés particular. Observa en efecto que estas convenciones imponen obligaciones a los Estados sin otorgarles ningún derecho, a diferencia de las convenciones multilaterales ordinarias que confieren a las partes tanto derechos como obligaciones.

Por otra parte, las referidas convenciones, desde un punto de vista de su forma orgánica, son elaboradas no solamente bajo los auspicios de organizaciones internacionales sino también en asambleas en las cuales se discuten largamente por todos los Estados, que pueden presentar libremente todas las observaciones que estimen útiles; a veces incluso son votadas por mayoría. Por cierto que ellas no se aplican todas automáticamente y permanecen sujetas a ratificaciones; pero cada día se ve más el desarrollo de un derecho convencional de un carácter muy particular, que es el derecho de las resoluciones. En efecto, en la organización internacional las resoluciones equivalen a lo que son los tratados en forma simplificada en las relaciones interestatales. Ustedes saben que los acuerdos en forma simplificada, que han adquirido una enorme importancia, son acuerdos que escapan a la necesidad de la ratificación.

Las resoluciones de determinadas asambleas internacionales tienen la misma característica en el sentido de que se aplican automáticamente y que se les considera de valor obligatorio.

Frecuentemente ellas se adoptan por simple mayoría, como es particularmente el caso de las resoluciones de la Asamblea General de las Naciones Unidas que de esta manera ejerce un verdadero poder legislativo, un poder de legislación colectiva.

Un latinoamericano no podía dejar de observar que también en este caso el ejemplo provenía del hemisferio occiden- 
tal. El sistema interamericano durante un período de seis o siete años en el curso de la guerra mundial se desarrolló, desde el punto de vista normativo y desde el punto de vista orgánico, cn condiciones extraordinarias sin que jamás hayan intervenido verdaderas convenciones sometidas a ratificación. Es por medio de resoluciones que el sistema creó múltiples instituciones, elaboró nuevas reglas y permitió, particularmente, que la solidaridad continental se expresara en un cuerpo muy nutrido de normas que emanaban de las Reuniones de Ministros de Relaciones Exteriores del sistema interamericano.

Esta técnica es la que tiende a desarrollarse en otras organizaciones internacionales. Alvarez considera que este poder legislativo supranacional, que comenzó a desarrollarse así en el nuevo mundo, es uno de los signos más curiosos de la evolución del derecho de los tratados.

Jugando con las palabras podría evidentemente sostenerse que no se refiere aquí a los tratados; Alvarez opina que es una simple cuestión de palabras y que, si bien no se trata de los tratados del derecho clásico, de todos modos se trata de cumplir la función legislativa que hasta ahora desempeñaban exclusivamente aquéllos, pero de una nueva manera y que quizás efectivamente exija de un vocabulario en sí mismo nuevo.

B) La interpretación de los tratados. De lo anterior de. duce Alvarez una consecuencia acerca de la interpretación de estas legislaciones y de estas nuevas reglamentaciones colectivas.

Estima, en efecto, que ya se trate de convenciones sometidas a ratificación como las que se enumeraron recién o de resoluciones aprobadas por una asamblea internacional, no deben obedecer a reglas de interpretación idénticas a aquellas que dominan la interpretación de los tratados en el derecho clásico.

En el derecho clásico se interpretaban los tratados como se interpretan los contratos en el derecho civil, pesando las 
expresiones, teniendo muy en cuenta las palabras e igualmente recurriendo con cuidado a los trabajos preparatorios para descifrar la verdadera voluntad de las partes, investigación que es tradicional en la interpretación de los contratos.

Al respecto explica que en el antiguo sistema la interpretación reunía las siguientes características:

- No se hacía distinción entre los tratados.

- Se era esclavo del texto.

- Cuando un texto resultaba oscuro se recurría a los trabajos preparatorios.

- Y una vez establecida la interpretación de un texto se le consideraba en cierta manera como inmutable; no se efectuaba ningún cambio, ni siquiera cuando la materia considerada hubiera evolucionado.

Hoy día, por el contrario, estima que es menester distinguir según los tratados, a la luz de las clasificaciones que él formuló $y$, por medio de esta distinción, buscar el objetivo social del tratado y no la intención de las partes. El tratado pierde su carácter voluntarista y adquiere un carácter institucional, incluso si se trata de una convención concluida al margen de una institución internacional entre dos o más Estados. En otras palabras es menester estudiar más los objetivos sociales que se persiguen que la voluntad de los autores; en seguida debe permitírseles cvolucionar para alcanzar esos objetivos. En estas condiciones, el intérprete ya no es más esclavo del texto como lo era en un derecho inspirado en la técnica contractual.

Más todavía, piensa él, salvo en casos excepcionales, debe excluirse de la interpretación de los tratados, aunque sean oscuros, y sobre todo de aquellos que se refieren a organizaciones internacionales, el examen de los trabajos preparatorios. En efecto, estos trabajos tienen cada día menos valor.

Por una parte, se encuentra todo tipo de opiniones, observando también que los Estados, e inclusive las comisiones, luego de haber sostenido una idea la abandonan para adoptar otra. 
Por otra parte, destaca Alvarez, cuando los Estados firman un tratado no toman en consideración los trabajos preparatorios que frecuentemente ni siquiera conocen. Además, el creciente dinamismo de la vida internacional exige que los textos siempre se encuentren en armonía con esta vida. Por tanto cs menester proceder - y esta opinión me parece esencialen la interpretación de los tratados, particularmente en la Carta de las Naciones Unidas, teniendo en cuenta el futuro: Un tratado, un texto, una vez que ha sido establecido adquiere vida propia; por consiguiente hay que interpretarlo tomando en cuenta las exigencias de esta vida; la interpretación ya no es más inmutable sino que es antes que nada dinámica. Esta interpretación dinámica de los textos que tienen en sí mismos una vida propia, es ciertamente una de las fórmulas más características del pensamiento de nuestro autor.

Esta apreciación conlleva una consecuencia importante. Recordemos la frase de Valery: "Todos los tratados son firmados en medio de pensamientos subyacentes". Si en vez de buscar estos pensamientos subyacentes, analizamos las finalidades del texto que tiene su propia vida, seremos inducidos a concluir que alguno de ellos ni siquiera pueden scr objeto de reserva.

Este es el caso particularmente de aquellas convenciones que imponen el respeto a los derechos de la humanidad. La convención sobre genocidio no es a juicio de Alvarez susceptible de reserva. Sostiene él que estas convenciones, en razón de su naturaleza, constituyen un todo indivisible. El genocidio es un crimen. Ante un problema de este género no se pueden formular algunas reservas, admitir eventualidades o condicionar las facultades, pues seria contraxio a los fines que ellas persiguen, que es el interés general de la humanidad.

C) Extinción de los tratados. En fin, en tercer lugar -y en esta oportunidad seré muy breve-, la extinción de los tratados le parece obedecer a algunos principios en los cuales no necesito insistir puesto que han guiado todo nuestro curso. 
La extinción de los tratados se encuentra dominada por el principio de la cláusula rebus sic stantibus. Podrá objetarse que esta no es una respuesta. Es ahí precisamente donde se encuentra toda la dificultad. Ustedes saben que la extinción de los tratados plantea la oposición de dos reglas: la regla "pacta sunt servanda" que expresa la necesidad de la seguridad jurídica, la buena fe en los contratos y el respeto de la palabra empeñada; y la cláusula "rebus sic stantibus" que involucra la necesidad de una evolución.

¿Cómo conciliar estas dos reglas? Hasta ahora jamás se ha logrado y este es el problema fundamental del derecho internacional. No se ha logrado en el marco interestatal del derecho de relaciones de una sociedad que tiende a permanecer anárquica.

Pero, precisamente, Alvarez reconoce a este respecto -y sobre ello personalmente le sigo sin la menor reserva- que solamente la organización institucional puede permitir salir de esta impasse. En efecto, las dos reglas nos Ilevan a una impasse que el derecho de la sociedad interestatal clásica no permite resolver. Solamente se puede solucionar pasando a una sociedad institucional en que la adaptación del derecho convencional sca orgánicamente conducida, como lo intentó el articulo XIX del pacto de la Sociedad de las Naciones con una técnica desde luego insuficiente.

En consecuencia, es por medio del desarrollo de la organización internacional y de la jurisprudencia internacional, esclarecida por los principios directores y creadores que Alvarez le proporcionó durante tantos años, que podrá lograrse esta conciliación con alguna probabilidad de éxito.

\section{La responsabilidad internacional}

Los problemas de la responsabilidad también son apreciados por nuestro autor dentro de una óptica sumamente novedosa. 
Ustedes saben que la responsabilidad internacional descansa sobre un fundamento que en sí mismo es materia de discusión. Históricamente se basaba en la noción de falta. Particularmente en Grotius se trataba de una "culpa", de una "culpa negligendo"; es el caso frecuente de un Estado que descuidaba la adopción de determinadas disposiciones que le hubieran permitido impedir que se produjeran daños en perjuicio de extranjeros o de Estados extranjeros.

En la responsabilidad la prueba de una falta es evidentemente de cargo de la víctima. Ustedes no ignoran que una corriente ya antigua, que se remonta a comienzos de este siglo, tiende a basar la responsabilidad, tanto en el orden interno como en el orden internacional, ya no más en la noción de falta sino en una noción que excluya la falta y que frecuentemente recurre a la teoría del riesgo.

Dentro de esta segunda manera de plantear el problema de las responsabilidades, la victima ya no debe probar ninguna falta; le bastará probar un acto, un daño y una relación de causalidad entre el acto y el daño que ha sufrido para inmediatamente obtener una reparación sin necesidad de proporcionar otras pruebas.

Nuevamente asistimos aquí a un diálogo de sordos entre los partidarios de la falta y los partidarios del riesgo. Unos sostienen que la teoría de la falta es más justa; para los otros sólo la teoría del riesgo satisface su necesidad de justicia. En realidad, no se ubicaban en el mismo plano.

Cuando se apoya la teoría de la falta, la justicia que se tiene in mente es aquella que se refiere al autor del daño. Se estima que sería injusto castigar a alguien que no sea por su falta el autor del perjuicio. La víctima debe entonces probar la falta antes de condenar a quien la ha cometido.

Por el contrario, en el caso de la teoría del riesgo tam+ bién se tiene presente, in mente, un deseo de justicia, pero esta vez no se refiere al autor del daño sino a la víctima. Y se sostiene: es injusto en presencia de un daño someter a la victima a la difícil prueba que significa la demostración de una 
falta; es más natural, teniendo en cuenta además el desarrollo de los seguros, que la víctima por el solo hecho de haber sufrido un daño y que puede demostrar la relación causal entre cl acto que causa el daño y este daño - demostración mucho más fácil que la de una falta- pueda obtener una reparación.

Este problema ha afectado igualmente al derecho internacional. Todavía existe una doctrina que permanece apegada a la noción de falta, particularmente la doctrina anglosajona sostenida por autores como Borchard o como Oppenheim Lauterpacht.

La segunda actitud ha sido adoptada por la mayoría de la doctrina y finalmente también por la práctica de la jurisprudencia internacional desde la época de la Corte Permanente de Justicia Internacional, como consecuencia de la teoria que fue presentada principalmente por el jurista italiano Anzilotti. Este, en sus artículos publicados a partir de 1912 y en su tratado de derecho internacional, sostiene que el único fundamento de la responsabilidad internacional es la violación de la ley internacional. Es decir el acto ilícito. Esta teoría se acerca mucho más a la teoría del riesgo que a la de la falta.

La falta, en efecto, cs una noción subjetiva difícil de determinar; pone en juego valores individuales y espirituales. La falta es una noción a la vez individualizada y espiritualiza. da. De ahí justamente la dificultad para establecerla.

El acto ilícito, en cambio, es una noción objetiva más fácil de comprender y más fácil de establecer.

Esta teoria de Anzilotti ha tenido un gran éxito en el derecho internacional derivado del hecho de que el acto ilícito como noción objetiva atenta menos en contra de la soberanía y la susceptibilidad de los Estados que la noción de falta, la cual se fundamenta en un juicio de valores que pone en juego consideraciones personales y vejatorias. Siempre puede cometerse un acto ilícito de buena fe; de todos modos deberá darse una reparación porque el daño ha sido causado. En derecho interno desde hace tiempo el Estado está sujeto a res- 
ponsabilidades pues el principio de la legalidad al cual se encuentra sometido ha permitido establecer un contencioso de responsabilidad del Estado respecto de los individuos. Si el Estado acepta ser perseguido por ilegalidad en el ordenamiento interno, no hay ninguna razón seria para que no lo acepte en el ordenamiento internacional. De hecho esta teoria ha tenido una gran influencia.

¿Cuál es la actitud de Alvarez frente a estas dos opciones fundamentales: responsabilidad por falta o responsabilidad por riesgo?

Para Alvarez no hay dudas al respecto. Se guía por los imperativos de la justicia social, es decir, considera esencialmente el interés de la víctima en mucho mayor grado que el interćs del autor del daño. Desde luego para ello hay una razón que se inspira en preocupaciones humanistas: la víctima frecuentemente es un individuo o un conjunto de individuos. La teoría objetiva de la responsabilidad favorece por tanto las posibilidades de reparación para la víctima.

Por otra parte, la teoría del acto ilícito es simple y de una aplicación aparentemente más fácil. Sin embargo, también en este caso este incorregible realista observa que de todos modos en el orden internacional el acto ilícito no es tan fácil de determinar, pues la norma internacional no siempre es muy precisa; él mismo constantemente ha cuestionado la existencia del derecho tradicional. En estas condiciones lo ilícito no siempre es fácil de percibir. Por esta razón es que en definitiva va más lejos que la doctrina de Anzilotti en el deseo de permitir en todo momento que la victima obtenga una reparación.

¿Cómo logra esto? Realizando una distinción entre tres fuentes de responsabilidad:

\section{Las fuentes de responsabilidad}

- La primera fuente es el acto ilícito, es decir, el acto contrario a una norma internacional cierta y conocida, parti- 
cularmente el acto contrario a un tratado. Es la responsabilidad en el sentido de Anzilotti, pero a esto agrega:

-La segunda fuente es el acto que causa el daño, es decir, un acto que causa daño sin ser ilícito; sin esta precisión no se podría apreciar la especificidad de esta categoría. Pueden causarse perjuicios a un Estado, o con mayor frecuencia a nacionales de un Estado, sin que el acto sea contrario a una norma internacional. Este es el caso de la insurrección o de una guerra civil, que no son actos contrarios a la ley internacional; los pueblos pueden buscar libremente $-y$ este es un principio clásico del derecho de gentes que nadie ha cuestionado- las formas políticas que consideren conveniente darse. Ciertamente los extranjeros que se encuentran en el territorio de este pais pueden ser afectados, pero no puede fijarsc el ordenamiento constitucional interno como tampoco podría paralizarse la evolución del ordenamiento internacional. Sin embargo, en los casos de insurrección y de guerra civil, el régimen de la responsabilidad del Estado, que en la actualidad es sumamente débil (17), debe para Alvarez plantearse de una manera absoluta porque es una regla de justicia social para las víctimas; y si no se actúa de esta manera se corre el riesgo de contravenir los vínculos de interdependencia social y de las necesidades de las relaciones internacionales del comercio jurídico en el sentido amplio de la expresión (18).

-En fin, en tercer lugar, ven como fuente de la responsabilidad internacional al delito internacional.

El delito internacional es el acto contrario a la humanidad. Es particularmente el genocidio. Este tipo de acto, proscrito por la conciencia internacional, de todos modos debe ser castigado haya o no un texto a su respecto.

(17) Vease Charless Rotrssean "Derecho Internacional Público", 1953, Nus. 471-480.

(18) Cabe tambjén preguntarse si acaso dentro de esta categoria debe contemplarse eventualmente la responsabilidad del Estado por expropiaciones de empresas extranjeras sin una suficiente indemnización. Esta materia tiene en la actutalidad un gran iu. ferés como consecuencia de una tendencia muy marcada hacia las nacionnlizaciones. Pero en esta oportunidad sólo invocamos el problema. 


\section{PALABRAS FINALES}

He aquí expuesta esta doctrina de Alejandro Alvarez y precisamente en el momento en que señalo esta tercera fuente de responsabilidad que es el delito internacional contrario a la humanidad, a su destino y a su conservación, me parece que alcanzamos el punto último de este pensamiento en perpetuo trabajo. Es incuestionable que en cierta medida, y ustedes no habrán dejado de observarlo, este pensamiento se encuentra notablementc avanzado en diversas materias que han sido consideradas como logros del derecho internacional positivo.

Por este hecho se han formulado algunos reproches a Alejandro Alvarez, por presentar a veces como normas positivas principios que todavía siguen siendo cuestionados en la actualidad. En cierta medida este reproche tiene fundamento, pero también en gran medida es excesivo.

Tiene fundamentos si se procura ver en la doctrina de Alvarez una descripción muy precisa de la práctica diplomática o judicial internacional. Pero esta crítica no puede alcanzarlo pues precisamente se desmiente con el conjunto de la obra de Alvarez, la cual por definición se encuentra proyectada hacia cl futuro, orientada hacia la vida, es decir, hacia lo que se hace cada día y que jamás se parece a lo que se ha realizado el día anterior.

Sobre estas bases no podríamos quejarnos de que el derecho nuevo no sca todavia un derecho enteramente positivo, pues el propio Alvarez ha clasificado con cuidado las reglas, los principios, los dominios y los problemas que ćl considera ya dominados por el nuevo derecho, aquellos que por el contrario le parecen todavía derivar del antiguo, así como igualmente ha tratado de sistematizar los principios de los dominios que participan de un derecho que todavía está en formación.

Tiene por tanto una visión muy precisa de estos tres planos. Su concepción es dialéctica y son pujantes los deseos que 
formula para el advenimiento más acelerado del nuevo derecho internacional.

Cabe simplemente agregar que el punto de vista con que Alejandro Alvarez examina el derecho internacional es exactamente el mismo que había sido adoptado antes que él por Suárez, Vittoria y Grotius, quienes tampoco se contentaban con examinar el derecho positivo de su tiempo --lo que evidentemente es de todos modos la función esencial del jurista, su justificación primera y que jamás hay que perder de vista-, sino que deseaban sobre todo guiar a los príncipes, a las autoridades y a los dominios, puesto que se encontraban en una época de transición, que veía el fin de un mundo y que se llamaba el Renacimiento.

Nosotros también nos encontramos hoy día -y Alvarez nos lo ha dicho frecuentemente- en una época de transición esforzándonos por traspasar el Cabo de las Tempestades. Y entonces, puesto que también vivimos en una época nueva, es bueno que ésta como aquélla encuentren, aquí y allá, sus fundadores. 
INDICE ANALITICO DE LAS MATERIAS CONSIDERADAS POR

ALEJANDRO ALVAREZ EN SUS OPINIONES DISIDENTES O

INDIVIDUALES EN LA CORTE INTERNACIONAL DE JUSTICIA.

ASILO: Asunto Haya de la Torre (Colombia v, Perú) Recueil 1950. Definición: pp. 291 - 292.

-Calificación del delito: Alvarez es de la opinión que la calíficación corresponde al Estado que concede el asilo, pero que en caso de controversia es la Corte que debe resolver. Rec. 1950, pp. 298-300 y 364.

-Urgencia: Es un problema de hecho. Si el Estado de refugio estima que existe urgencia, puede conceder el asilo; pero si el Estado territorial opina lo contrario, debe presentar inmediatamente una demanda, pues si no se presumirá haber admitido la urgencia. Rec. pp. 298 - 299.

-Término del asilo: Alvarez admite el derecho del Estado de refugio de reclamar un salvoconducto, con la condición de que no se controvierta la legalidad del asilo. Rec. p. 301.

CORTE DE JUSTICIA: La Corte no debe contentarse con constatar el derecho existente, sino que más todavía debe desarrollar el derecho. Tiene una misión creadora. Alvarez sostiene constantemente esta idea. Véase particularmente Rec. 1951, p. 50 y 177. Rec. 1952, p. 132.

DOMINIO RESERVADO: Rec. 1952, p. 127.

Derecho de Interdependencia social: Alvarez fundamenta cl nuevo derecho en la noción de interdependencia social. Esta idea fundamental es reafirmada en todas sus opiniones disidentes a partir de aquella formulada en 1948 en el caso de la admisión de miembros de las Naciones Unidas. Véase Rec. 1948, p. 69 y especialmente Rec. 1950, p. 176 y Rec. 1952, pp. $124-128$. 


\section{DERECHO NUEVO:}

Dinámico: Rec. 1952 p. 124.

No es un ideal sino una realidad. Rec. 1952, p. 125.

DERECHO INTERNACIONAL Y DERECHO INTERNO: El derecho internacional prevalece sobre el derecho interno. Rec. 1950, p. 181. Rec. 1951, p. 152.

DERECHO INTERNACIONAL GENERAL Y DERECHO PARTICU$L A R$. En la actualidad existen varios derechos continentales. Rec. 1950. p. 294.

Estos dos derechos no se encuentran en relación de subordinación, sino de correlación. Rec. 1950, pp. 293-294. De esta manera Alvarez permanece fiel a su doctrina sobre este particular, tal como la formuló en 1910 en su obra "Le Droit International American". Véase tambićn Rec. 1952, p. 127.

MANDATOS Y FIDEICOMISOS: Son funciones internacionales. Rec, 1950, p. 180. Por otra parte no hay cuestiones de soberanía en juego en esta institución. Rec. 1950, p. 180.

E1 Fideicomiso sucede de pleno derecho a los mandatos. Rec. 1950, pp. $181-182$.

MAR: Mar territorial: El paso inocente no es una tolerancia sino que se ha transformado en un derecho para las naves de comercio. Rec. 1949, p. 46. Los navíos de guerra no tienen un derecho sin restricción alguna sino cuando cumplen una misión internacional confiada por la Organización de las Naciones Unidas. Rec. 1949, p. 47.

ORGANIZACION INTERNACIONAL (O.N.U.): La O.N.U. debe ser reconocida como persona de Derecho Internacional. Alvarez manifiesta su dicha por el reconocimiento de esta materia por la Corte Internacional de Justicia. Rec. 1949, p. 191.

-Admisión de miembros: En la opinión de Alvarez la Asamblea General debe desempeñar un rol activo y tiene el derecho de apreciar el veto que paraliza al Consejo de Seguridad. Rec. 1950, p. 19.

-Interpretación de la Carta: La Carta es un medio y no un fin. Rec. 1950, p. 20. La Asamblea General debe poder investigar en la medida necesaria si hay abuso del derecho de veto $y$, en caso afirmativo. puede proceder a la admisión sin la recomendación del Consejo. 
-Organo creado por la Asamblea General: Tribunal administrativo. La Asamblea tiene el derecho de negarse a ejecutar un fallo de este tribunal si tiene para ello motivos graves (exceso de poder, injusti. cia manifiesta contraria a la noción de justicia social internacional o violación de los grandes principios del derecho internacional). Rec. 1954. p. 75 .

Si una controversia presenta un aspecto político y un aspecto jurídico bicn separados, el primero incumbe a la competencia del Consejo de Seguridad y cl segundo a la Corte.

PRINCIPIOS GENERALES: Comprenden particularmente la buena fe y la "condenación del abuso del derecho debe ser transportada al nucvo Derecho Internacional". Alvarez se refiere a esta noción en la mayoría de sus opiniones disidentes. Véase particularmente Rec. 1949, p. 48 y Rec. 1950 , p. 15.

SOCIEDAD INTERNACIONAL: LOS Estados ya no constituyen hoy día una simple comunidad, sino una verdadera sociedad internacional. Rec. 1954, p. 69.

\section{SOBERANIA RESPONSABILIDAD INTERNACIONAL:}

-Noción: Alvarez distingue tres fuentes de la responsabilidad:

a) El delito internacional, acto contrario a los sentimientos de humanidad.

b) El acto que produce daño a un Estado en la persona de sus nacionales (insurrección, guerra civil).

c) El acto ilícito, contrario a la ley internacional (a un tratado). Rec. 1949, pp. 44-46.

-Reclamación de indemnización: Alvarez indica los casos en los cuales un Estado puede, en conformidad al derecho vigente, presentar una reclamación. Rec. 1952, p. 129.

Alcances del artículo 36 del Estatuto de la Corte Internacional de Justicia: es la Corte que debe determinarlo. Rec. 1952, pp. 130-131.

\section{TRATADO MULTILATERAL:}

-Clasificación: Alvarez divide las convenciones en cuatro categorías: las convenciones que se proponen desarrollar la organización internaciona!; aquellas que establecen un estatuto territorial; aquellas 
que han establecido los grandes preceptos del Derecho de Gentes; y aquellas que tienden a mejorar la situación social y humanitaria de los individuos. Rec. 1951, p. 51.

-Extinción de los tratados: El principio que inspira la cláusula "rebus sic stantibus" es el de la justicia social. Rec. 1949, p. 41. Ello resfuerza el rol creador de la Corte de Justicia que debe apreciar la caducidad de los tratados.

-Interpretación de los tratados: Alvarez contrapone el sistema antiguo con el nuevo. Rec. 1950, pp. 16-19. Alcance que debe darse a los trabajos preparatorios. Rec. 1950, p. 178; Rec. 1948, p. 68 y Rec. 1952 p. 126.

-Reservas: Determinadas convenciones, particularmente aqueIlas que se refieren al genocidio, no son susceptibles de reservas. Rec. 1951 p. 63. Las convenciones universales deben referirse solamente a los puntos esenciales, sin entrar en detalles, de tal manera que puedan ser aceptadas por el mayor número de Estados. Rec. 1951 pp. 53-54.

N B.-Este índice no pretende ser completo; se remite simplemente a los pasajes de las opiniones de Alvarez que nos han parecido los más significativos. 